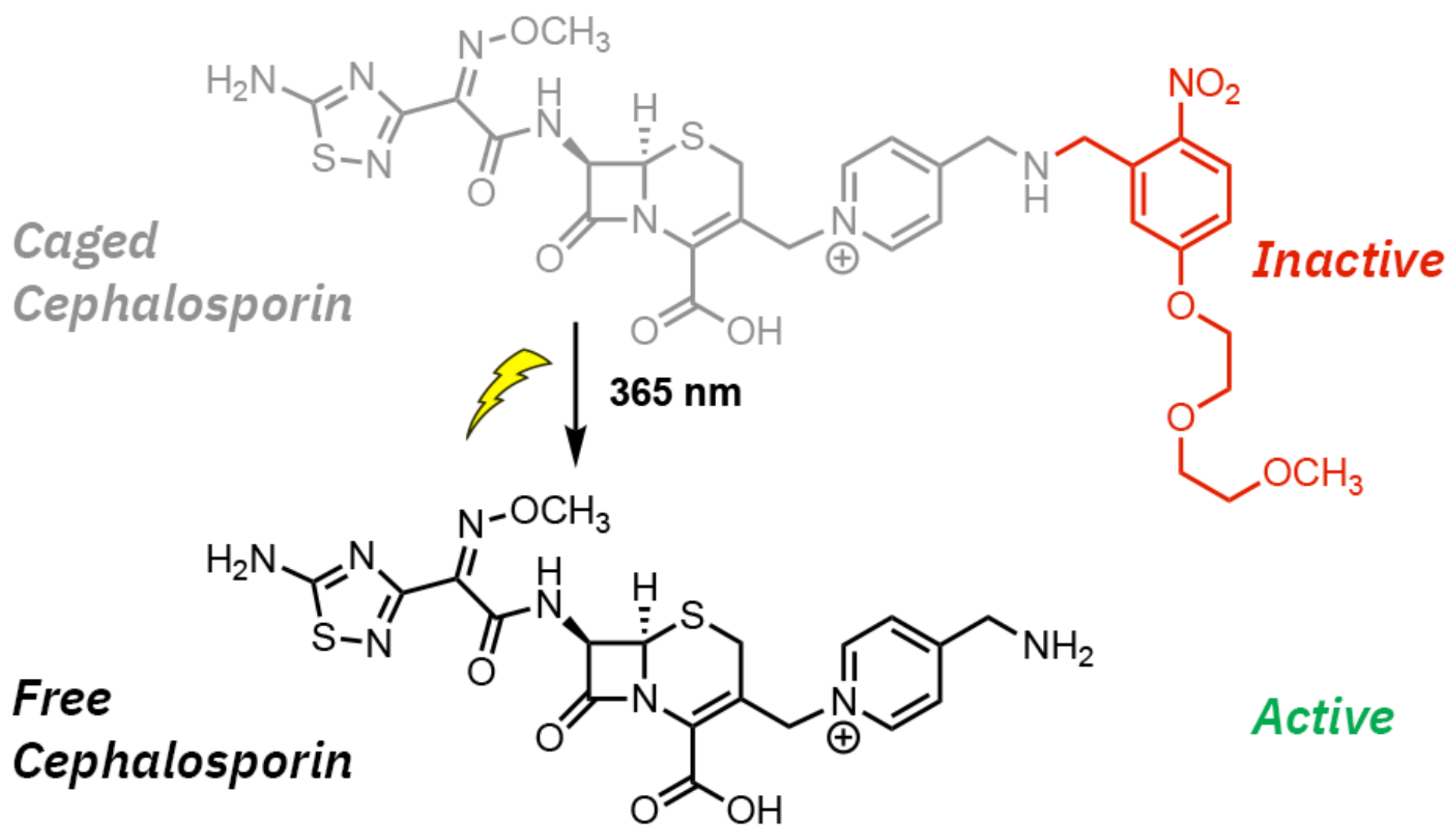




\title{
Design, Synthesis, and Biological Evaluation of Light-Activated Antibiotics
}

2
Inga S. Shchelik, Andrea Tomio, and Karl Gademann

Department of Chemistry, University of Zurich, Winterthurerstrasse 190, 8057, Zurich, Switzerland

\begin{abstract}
The spatial and temporal control of bioactivity of small molecules by light (photopharmacology) constitutes a promising approach for study of biological processes and ultimately for the treatment of diseases. In this study, we investigated two different 'caged' antibiotic classes that can undergo remote activation with UV-light at $\lambda=365 \mathrm{~nm}$, via the conjugation of deactivating and photocleavable units through a short synthetic sequence. The two widely used antibiotics vancomycin and cephalosporin were thus enhanced in their performance by rendering them photoresponsive and thus suppressing undesired off-site activity. The antimicrobial activity against Bacillus subtilis 4 ATCC 6633, Staphylococcus aureus ATCC 29213, S. aureus ATCC 43300 (MRSA), Escherichia coli ATCC 25922, 5 and Pseudomonas aeruginosa ATCC 27853 could be spatiotemporally controlled with light. Both molecular series 6 displayed a good activity window. The vancomycin derivative displayed excellent values against Gram-positive strains after uncaging, and the next-generation caged cephalosporin derivative achieved good and broad activity against both Gram-positive and Gram-negative strains after photorelease.
\end{abstract}

9 Key words: antibacterial agents, photopharmacology, photocaging, vancomycin, cephalosporin. 
21 Pharmacotherapy often remains the treatment of choice for many diseases via suitable medication. ${ }^{1}$ However, this approach is often associated with issues related to environmental toxicity, ${ }^{2}$ poor drug selectivity causing side-effects, ${ }^{3}$ and the emergence of resistance in certain disease areas such as infectious diseases. ${ }^{4-6}$ So far, several stimuliresponsive systems have been developed to overcome these issues, including either endogenous stimuli (such as enzyme, $\mathrm{pH}$, redox reactions) or exogenous stimuli (such as light, ionizing irradiation, magnetic fields). ${ }^{7,8}$ In terms of exogenous approaches, photopharmacology has demonstrated excellent performance in achieving control of time, area, and dosage of therapeutics by light. ${ }^{9-11}$ The development of such strategies includes incorporation of photoswitchable groups into the molecular structure of bioactive compounds, ${ }^{12-22}$ introduction of functional groups for light-triggered drug self-destruction, ${ }^{23}$ or in general 'caging' the activity of compounds. ${ }^{24-27}$ In this respect, caged compounds include photoactivatable probes such as photo-protecting groups, photocleavable linkers, or photodegradable peptides, ${ }^{28,29}$ and these compounds remain biologically or functionally inert prior to uncaging. Photoactivation of caged compounds enables the spatiotemporal regulation of the activity of the drugs of interest, which has been successfully applied as powerful tools in biological studies. There are many examples of successful utilization of photocaging handles directly on antitumor drugs,${ }^{30-33}$ neurotransmitters, ${ }^{34-36}$ or peptides. $^{37}$ Related to antibiotics, there have been many examples of photoswitchable groups attached to antibiotics, which have been demonstrated to successfully inhibit bacterial growth by irradiation. ${ }^{12,14-16,19,20,22,38}$ However, thermodynamic equilibration of the photoswitches invariably leads to a decrease of antibiotic activity over time, often during the application. In order to prevent bacterial regrowth, constant and longer irradiation needs to be employed, which consequently might lead to side-effects due to undesired prolonged UV irradiation.

In contrast, photocaging of antibiotics presents the complementary and unique strategy of releasing the active compounds ad finitum. Advantages of this strategy include (1) short exposure to UV light, (2) release of maximum concentration within a short time frame, and (3) prolonged activity of the antibacterial agents. Interestingly, there are only few reports on photocaged antibiotics, used for the study of protein translation, ${ }^{39,40}$ hydrogel modification for antibacterial wound dressings, ${ }^{41}$ blocking the group responsible for antibiotic activity, ${ }^{42,43}$ or living organism functionalisation. ${ }^{44}$ However, to the best of our knowledge, examples remain very scarce and the important classes of vancomycin and cephalosporin antibiotics have not been addressed so far. In this study, we report the control of activity of two widely used antibiotics vancomycin and cephalosporin, where the caging functionality was appended to the pharmacophore. We demonstrate that UV-light exposure at $\lambda=365 \mathrm{~nm}$ uncages the precursor antibiotics and thereby releases antibacterial activity in the presence of bacteria.

50 Vancomycin and cephalosporin are members of the class of antibiotics that inhibit the cell wall biosynthesis in 51 bacteria. ${ }^{45}$ Both drugs remain on the World Health Organization's List of Essential Medicines. ${ }^{46}$ Vancomycin is 52 active against Gram-positive bacteria and widely used in clinics worldwide, especially for the treatment of 53 methicillin-resistant Staphylococcus aureus (S. aureus, MRSA) ${ }^{47}$ We evaluated members of the $4^{\text {th }}$ generation of 54 cephalosporins, which feature inhibitory effects against various Gram-negative bacteria, including Pseudomonas 
aeruginosa (P. aeruginosa). ${ }^{48,49}$ The evolution of microbial resistance to vancomycin and cephalosporins is an emerging problem, that renders those particularly interesting candidates for photopharmacology. ${ }^{50,51}$ The development of photoresponsive analogues and control of their activity could reduce undesirable bacterial interactions with the active drug form, thus limiting the progress of bacterial resistance.

\section{RESULTS AND DISCUSSION}

We chose to employ a dual strategy featuring both a photocleavable group for caging combined with a PEGylation approach for steric blocking. We hypothesized that the introduction of a relatively long PEG chain to vancomycin will suppress its activity and prevent binding with the terminal amino acid residues of the nascent peptide chain during cell wall synthesis. In case of cephalosporin, we expected to either avert the insertion of the drug into penicillin-binding protein (PBP) or prevent transport issues by e.g. bacterial pumps by this approach. As consequence for the design, compounds $\mathbf{1}$ and $\mathbf{2}$ were chosen as the target caged antibiotics of our study, which should release active compounds $\mathbf{3}^{44}$ and $\mathbf{4}$. The good antibacterial activity of similar pyridinium cephalosporin derivatives was shown earlier in several studies ${ }^{52,53}$ and patents ${ }^{54}$. Compounds $\mathbf{5}$ and $\mathbf{6}$ serve as control compounds to evaluate the role of the PEG blocking group. Vancomycin has been modified according to a previously reported strategy at the carboxylic acid position, ${ }^{44,55}$ and the cephalosporin modification was extending the C-3' position of the cepham ring system with a nitrobenzyl caging group sterically modified by ethylene glycol units.

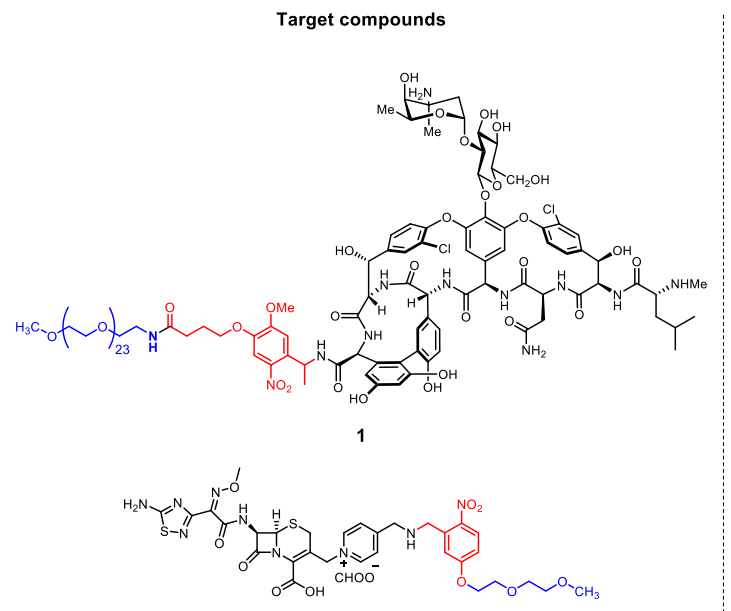

2

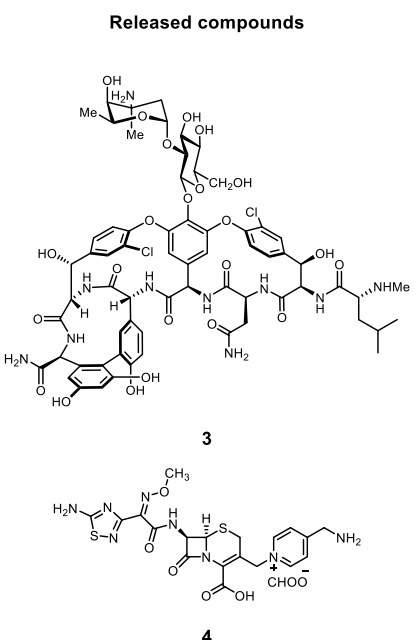

4

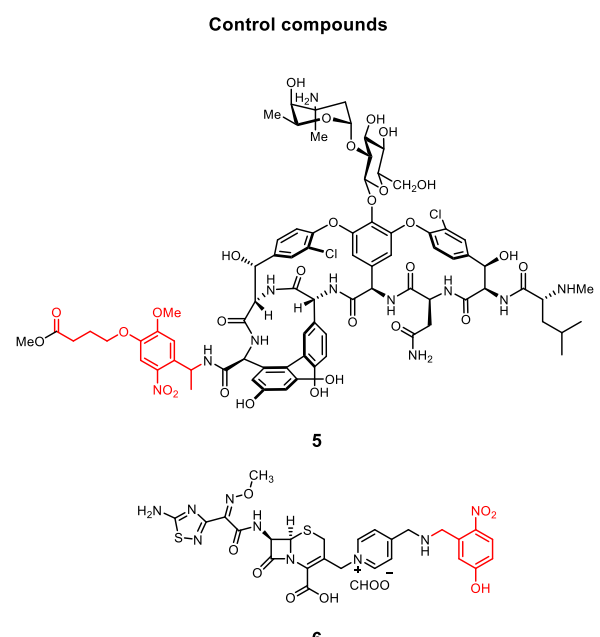

6

The synthesis of target vancomycin derivative 1 started with the linker preparation (Scheme 1). The acid functionality of the Fmoc-Photo-Linker 7 was used for incorporation of the PEG chain via amide bond formation (-> 8a), followed by Fmoc deprotection leading to the desired linker $9 \mathrm{a}$ with $60 \%$ yield over two steps. The last step included coupling the obtained linker with vancomycin hydrochloride in presence of PyBop and HOBt as coupling agents to give target compound 1. Analogously, the control compound $\mathbf{5}$ without the PEG chain was obtained via intermediates $\mathbf{8 b}$ and 9b in similar yields. The synthesis of target cephalosporin derivative 2 started with an $\mathrm{S}_{\mathrm{N}} 2$ reaction between the phenolate of 2-nitro-5-hydroxybenzaldehyde 10 and 1-bromo-2-(2-methoxyethoxy)ethane (Scheme 2) to give 11 a. Next, reductive amination to 12a with 4-(aminomethyl)pyridine was carried out. Carrying out this reaction with stepwise addition of the reducing agent could improve the performance of the reaction and correspondingly, the yield. For the key coupling with the cephalosporin core, the secondary N-atom on the intermediate amine had to be blocked. 
The attempt to attach the linker directly to the cephalosporine core $\mathbf{1 4}$ led to the formation of undesired products. A Boc protecting group was chosen to block the reactivity of secondary amine on the linker, and after the screening of several conditions, the use of THF as a solvent was crucial for the reaction, in order to achieve full conversion and to avoid decomposition. The desired linker 13a was obtained via this route in $23 \%$ yield over 3 steps. The key coupling reaction with cephalosporin 14 included three straight forward steps without the isolation of intermediates. Moreover, both Boc and PMB protection groups could be removed in one step in presence of trifluoroacetic acid (TFA) and anisole, to give the target compound, albeit in poor yield. Along the same lines, the preparation of control compound 6 was achieved by using transient MOM protection via intermediates $11 \mathbf{b}, \mathbf{1 2 b}$, and 13b, and the active compound 4 was obtained by direct reaction of core 14 with 4-(aminomethyl)-pyridine.

Scheme 1. Synthesis of UV-light regulated vancomycin derivatives 1 and $\mathbf{5}$.<smiles>COc1cc(C(C)NC=CC2CCCC2)c([N+](=O)[O-])cc1OCCCC(=O)O</smiles><smiles>[R1]C(=O)CCCOc1cc([N+](=O)[O-])c(C(C)[NH+]=[Fe])cc1OC</smiles><smiles>[R]C(=O)CCCOc1cc([N+](=O)[O-])c(C(C)N)cc1OC</smiles>

8a: $\mathrm{R}^{1}=-\mathrm{NH}_{2} \mathrm{CH}_{2} \mathrm{CH}_{2} \mathrm{PEG}_{23} \mathrm{OMe}$

8b: $R^{1}=O M e$

9a: $\mathrm{R}^{1}=-\mathrm{NH}_{2} \mathrm{CH}_{2} \mathrm{CH}_{2} \mathrm{PEG}{ }_{23} \mathrm{OMe}$

9b: $R^{1}=\mathrm{OMe}$

${ }^{a}$ Reagents and conditions: (a) MeO-PEG 24 -amine, HATU, DIPEA, DMF, $2 \mathrm{~h}, \mathrm{rt}, 72 \%$ for $\mathbf{8 a}$. (b) $\mathrm{MeOH}, \mathrm{H}_{2} \mathrm{SO}_{4}, 50{ }^{\circ} \mathrm{C}$, overnight, $97 \%$ for $\mathbf{8 b}$. (c) $20 \%$ piperidine, DMF, 1-2h, rt, $83 \%$ for $\mathbf{9 a}, 95 \%$ for $\mathbf{9 b}$. (d) Vancomycin hydrochloride, PyBop, HOBt, DMF, 2h, rt, $28 \%$ for $\mathbf{1}$ from $\mathbf{9 a}$, $30 \%$ for $\mathbf{5}$ from $\mathbf{9 b}$.

Scheme 2. Synthesis of cephalosporin derivatives $\mathbf{2 , 4}$, and $\mathbf{6}$.<smiles>O=Cc1cc(O)c2ccccc2c1[N+](=O)[O-]</smiles><smiles></smiles><smiles>[R17]Oc1ccc([N+](=O)[O-])c(C=O)c1</smiles><smiles>C1CCC1</smiles>

11a: $R^{1}=-P E G_{2} M e$

10

11b: $R^{1}=M O M$<smiles>CO/N=C(\C(=O)N[C@@H]1C(=O)N2C(C(=O)OC)=C(CCl)CS[C@@H]12)c1nsc(N)n1</smiles>

14<smiles>[R17]Oc1ccc([N+](=O)[O-])c(CN([R])Cc2ccncc2)c1</smiles>
12a: $R^{1}=-P E G_{2} M e, R^{2}=H$ 12b: $R^{1}=M O M, R^{2}=H$ 13a: $R^{1}=-\mathrm{PEG}_{2} \mathrm{Me}, \mathrm{R}^{2}=\mathrm{Boc}$ 13b: $R^{1}=M O M, R^{2}=$ Boc

${ }^{a}$ Reagents and conditions: (a) 1-bromo-2-(2-methoxyethoxy)ethane, $\mathrm{K}_{2} \mathrm{CO}_{3}, \mathrm{DMF}, 90^{\circ} \mathrm{C}$, overnight, $98 \%$ for 11a. (b) $\mathrm{MOMCl}$, DIPEA, DCM, $0^{\circ} \mathrm{C}->$ rt, $1.5 \mathrm{~h}, 85 \%$ for $\mathbf{1 1 b}$. (c) 4-(aminomethyl)pyridine, $\mathrm{NaBH}(\mathrm{OAc})_{3}, \mathrm{AcOH}, \mathrm{DCE}, 6 \mathrm{~h}, \mathrm{rt}, 63 \%$ for 12a, 48\% for 12b. (d) Boc $2 \mathrm{O}, \mathrm{THF}, 3 \mathrm{~h}$, $\mathrm{rt}, 49 \%$ for $\mathbf{1 3 a}, 55 \%$ for $\mathbf{1 3 b}$. (e) NaI, acetone, $1 \mathrm{~h}$, rt, then 13a or 4-(aminomethyl)pyridine or 13b, acetone, 3-5h, rt, then anisole, TFA, DCM, 2-6h, rt, $2 \%$ for $2,10 \%$ for $4,1 \%$ for 6 .

The general photochemistry of compounds $\mathbf{1}$ and $\mathbf{2}$ was studied next. In an earlier study, we investigated the photoproperties of similar vancomycin analog with the same nitrobenzyl photo group attached. ${ }^{44}$ It was demonstrated that the release of vancomycin amide 3 takes place rapidly during the UV-irradiation ( $\lambda=365 \mathrm{~nm}$ ) of a vancomycin derivative with photocleavable linker and reaches a maximum of $70 \%$ after $5 \mathrm{~min} .{ }^{44} \mathrm{Next}$, the photocleavage efficacy 
108 of cephalosporin derivative $\mathbf{5}$ was investigated. It was shown that the cephalosporin with pyridyl-methylamine moiety

1094 as a product was released after UV-irradiation ( $\lambda=365 \mathrm{~nm}$, Figure $\mathrm{S} 1)$. Moreover, the same tendency in efficacy for 110 the photocleavage of the linker was observed compared to the vancomycin derivative. The maximum conversion of 111 roughly $70 \%$ was observed after only 6 min of irradiation (Figure S2). Importantly, no by-products except of the 112 cleaved linker could detected after the photocleavage by UHPLC-MS (Figure S4).

113 The antimicrobial activity studies of all obtained compounds were investigated by performing a broth dilution method 114 according to the EUCAST standard protocol. ${ }^{56}$ The minimum inhibitory concentration (MIC) of the target 115 compounds $\mathbf{1}$ and 2, compounds released after UV-irradiation $\mathbf{3}$ and 4, as well as control compounds 5 and $\mathbf{6}$ were 116 determined against two Gram-negative strains E.coli ATCC 25922 and P. aeruginosa ATCC 27853, and three Gram117 positive strains $B$. subtilis ATCC 6633, S. aureus ATCC 29213 (VSSA), S. aureus ATCC 43300 (MRSA) (Table 1). 118 As was expected, PEG containing vancomycin derivative 1 did not display significant activity against Gram-positive 119 strains with a MIC value more than $64 \mu \mathrm{g} / \mathrm{mL}$. In contrast, the compound 3 lacking a PEG group displayed excellent 120 activity with MIC values of $0.125 \mu \mathrm{g} / \mathrm{mL}$ and $1 \mu \mathrm{g} / \mathrm{mL}$ against $B$. subtilis and $S$. aureus, respectively, similar to 121 vancomycin itself. Moreover, released vancomycin amide $\mathbf{3}$ featured the same MIC values compared to 122 vancomycin. ${ }^{44}$ These experimental observations corroborate the hypothesis that the presence of long PEG chains is 123 necessary for low antibacterial activity of vancomycin derivatives.

124 Concerning cephalosporin derivatives, an insertion of PEG linker lowered the antibiotic activity against all the tested 125 strains, as shown in table 1. The released cephalosporin derivative 4 exhibited especially high activity against Gram126 negative strains with a MIC value of $2 \mu \mathrm{g} / \mathrm{mL}$, however it turned out to be less active against Gram-positive strains, 127 especially $S$. aureus. This can be explained by the fact that cephalosporins possessing a thiadiazole side chain and 128 zwitterionic properties in their core exhibit low $\beta$-lactamase hydrolysis and higher penetration rate through the outer membrane, what renders them especially active against Gram-negative bacteria. ${ }^{57,58}$ For the control compound 6 having only a nitrobenzyl group, the MIC value decreased only for P. aeruginosa. The significant difference in activity after the incorporation of photo-linker was not observed against other strains, which necessitates the need of the PEG chain in the structure. ${ }^{16}$ From these results we decided to focus on exploration cephalosporin activity against Gram-negative strains and vancomycin activity against Gram-positive bacteria for the next experiments on in situ cleavage.

Table 1. MIC values (in $\mu \mathrm{g} / \mathrm{mL}$ ) of vancomycin and cephalosporin derivatives. Red background denotes caged precursors, and green background denotes active uncaged antibiotics.

\begin{tabular}{llll|lll}
\cline { 2 - 7 } & \multicolumn{3}{c}{ Vancomycin Series } & \multicolumn{4}{c}{ Cephalosporin Series } \\
& $\mathbf{1}$ & $\mathbf{3}$ & $\mathbf{5}$ & $\mathbf{2}$ & $\mathbf{4}$ & $\mathbf{6}$ \\
\hline E. coli ATCC 25922 & - & - & - & 8 & $1-2$ & 1 \\
P. aeruginosa ATCC 27853 & - & - & - & 64 & $2-4$ & 32 \\
B. subtilis ATCC 6633 & 32 & $0.06-0.125$ & 0.125 & 8 & $2-4$ & 1 \\
S. aureus ATCC 29213 & $>64$ & $0.5-1$ & 0.5 & 32 & 8 & 4 \\
S. aureus ATCC 43300 & $>64$ & $1-2$ & 1 & 64 & 32 & 16
\end{tabular}


A time-resolved growth analysis in 96-well format was performed, in order to investigate the dynamic effect of target antibiotics 1 and $\mathbf{2}$ on the bacterial growth before and after irradiation. A series of 2-fold dilutions starting from 64$32 \mu \mathrm{g} / \mathrm{mL}$ of corresponding antibiotic was carried out in one half of a 96-wells plate. The solutions were UVirradiated for $5 \mathrm{~min}$ at $\lambda=365 \mathrm{~nm}$. Next, the dilution step was repeated in the second half of the same 96-wells plate followed by the bacteria inoculation at optical density $\mathrm{OD}_{600}=0.1$. The bacterial growth curves were recorded at $37^{\circ} \mathrm{C}$ by a plate reader, measuring the $\mathrm{OD}_{600}$ every 20 min during $18 \mathrm{~h}$. Vancomycin derivative $\mathbf{1}$ was first tested against the Gram-positive strain B. subtilis. The desired inhibition was observed for the solutions contained compound 1 starting from $1 \mu \mathrm{g} / \mathrm{mL}$ and above, after the UV-irradiation. In contrast, non-irradiated solutions did not impact on B. subtilis growth at all tested concentrations. No difference between "non-activated" and "activated" forms of vancomycin derivative 1 was observed at the concentration $0.5 \mu \mathrm{g} / \mathrm{mL}$ (Figure 1, A, B, Figure S5), which is fully compliant with MIC data for both compound $\mathbf{1}$, released form $\mathbf{3}$, and photocleavage efficacy of introduced linker.
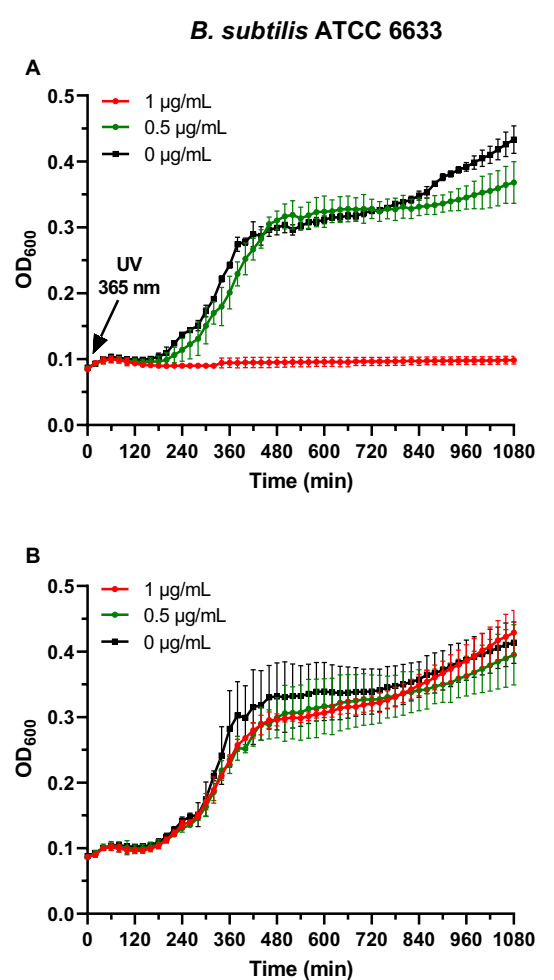

S. aureus ATCC 29213

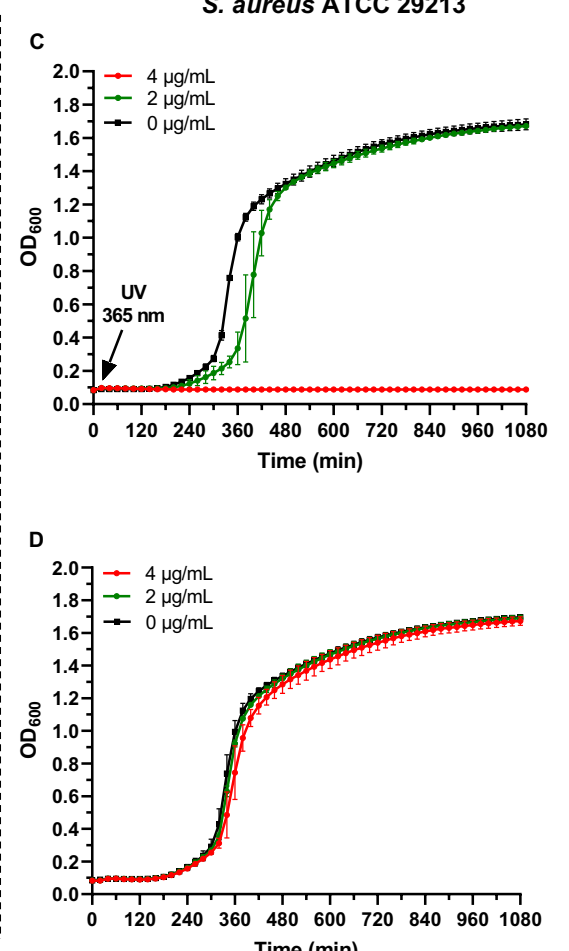

S. aureus ATCC 43300

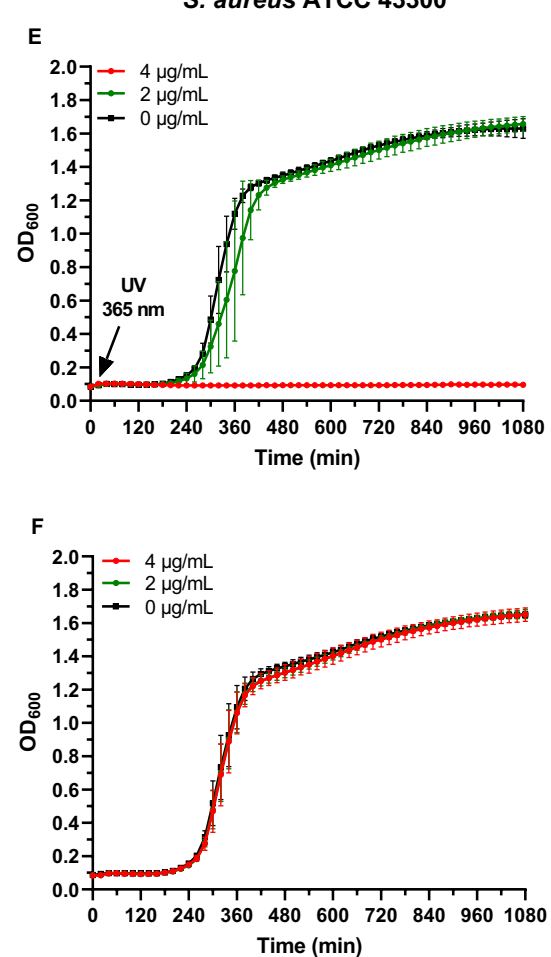

Figure 1. Bacterial growth curves of Gram-positive bacteria at decreasing concentrations of the vancomycin derivative 1. (A) Non-irradiated samples in presence of $B$. subtilis ATCC 6633. (B) Sample after irradiation at time 0 min with UV light at $\lambda=$ $365 \mathrm{~nm}$ for $5 \mathrm{~min}$ in presence of B. subtilis ATCC 6633. (C) Non-irradiated samples in presence of S. aureus ATCC 29213. (D) Sample after irradiation at time 0 min with UV light at $\lambda=365 \mathrm{~nm}$ for $5 \mathrm{~min}$ in presence of $S$. aureus ATCC 29213. (E) Nonirradiated samples in presence of $S$. aureus ATCC 43300 (MRSA). (F) Sample after irradiation at time 0 min with UV light at $\lambda$ $=365 \mathrm{~nm}$ for $5 \mathrm{~min}$ in presence of S. aureus ATCC 43300 (MRSA). All the solutions were irradiated before inoculation. Data points represent mean value $\pm \mathrm{SD}(\mathrm{n}=3)$

Next, the vancomycin derivative $\mathbf{1}$ was tested against difficult to treat strains of $S$. aureus, including MRSA strains. We were pleased to observe the effective inhibition of bacterial growth at the range of $4 \mu \mathrm{g} / \mathrm{mL}$ and above after an 5 minute UV-irradiation at $\lambda=365 \mathrm{~nm}$ of the antibiotic 1 (Figure 1C, 1E, Figure S6-S7). However, the normal bacterial 
growth remained for both vancomycin sensitive $S$. aureus (VSSA) and MRSA in presence of deactivated vancomycin derivative 1 at concentration $1 \mu \mathrm{g} / \mathrm{mL}$ and higher (Figure 1D, 1F, Figure S6-S7).

In the cephalosporin series, the antibacterial activity of compound 2 with different concentrations was first tested against Gram-negative strains $E$. coli and $P$. aeruginosa. From MIC results, we could identify a small window in activity between "non-activated" and "activated" forms of cephalosporin derivative $\mathbf{2}$ against $E$. coli. Corroborating these hypotheses, bacterial growth curve demonstrated that a concentration of $4 \mu \mathrm{g} / \mathrm{mL}$ of compound 2 delivered the expected difference in antibacterial activity before and after UV-irradiation (Figure 2A). In addition, the sample at the concentration $2 \mu \mathrm{g} / \mathrm{mL}$ resulted in slight inhibition of bacterial growth after the release of the cephalosporin active form. Unfortunately, starting from $8 \mu \mathrm{g} / \mathrm{mL}$ and higher, compound 2 implied inhibitory activity even without UVirradiation (Figure 2B, Figure S8).
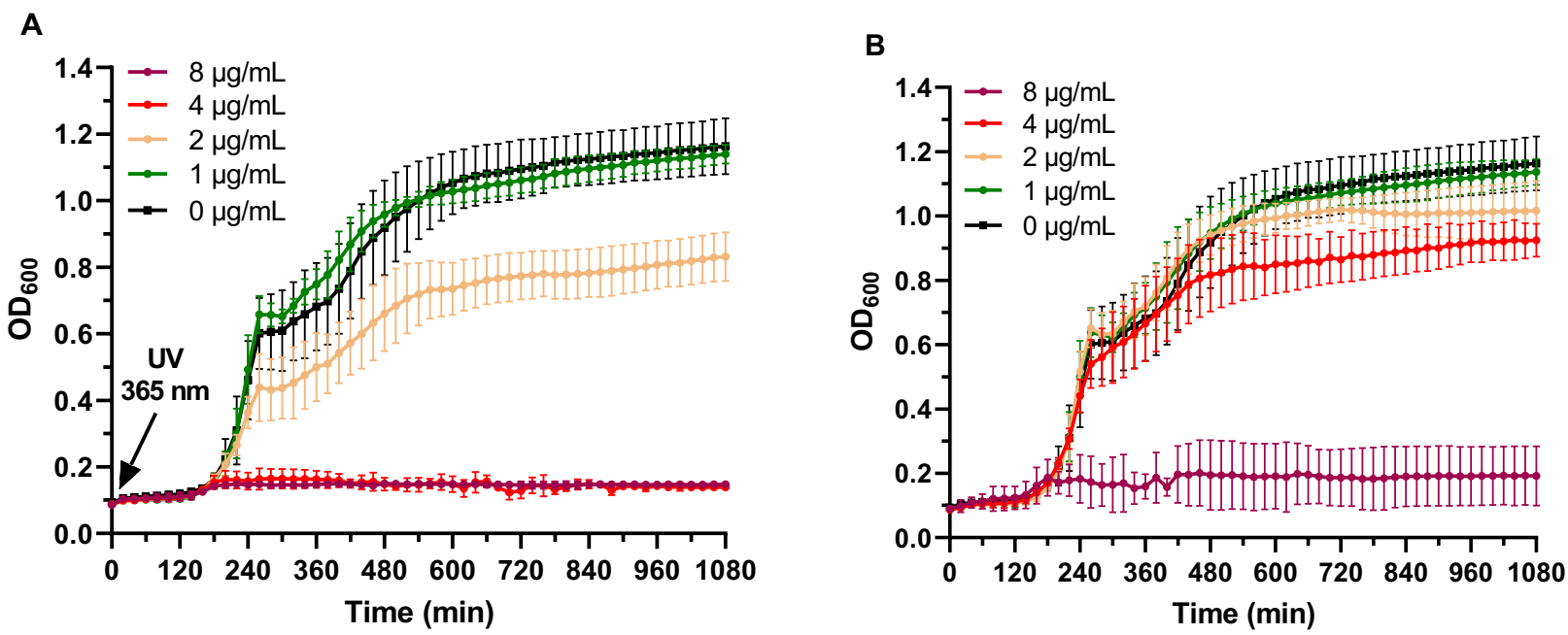

Figure 2. Bacterial growth curves of $E$. coli ATCC 25922 at decreasing concentrations of the cephalosporin derivative 2. (A) Sample after irradiation at time $0 \mathrm{~min}$ with UV light at $\lambda=365 \mathrm{~nm}$ for $5 \mathrm{~min}$. (B) Non-irradiated samples. All the solutions were irradiated before inoculation. Data points represent mean value $\pm \operatorname{SD}(n=3)$.

Next, the activity of cephalosporin derivative $\mathbf{2}$ at the different concentrations was tested against $P$. aeruginosa. After the release of active compound 4 significant inhibition of bacterial growth at concentration $32 \mu \mathrm{g} / \mathrm{mL}$ was observed (Figure 3A). The lower concentration of compound $2(16 \mu \mathrm{g} / \mathrm{mL})$ after UV exposure resulted in partial inhibition of $P$. aeruginosa growth and an extended lag phase of 12 hours. Moreover, the further decrease of cephalosporin derivative concentration to $8 \mu \mathrm{g} / \mathrm{mL}$ correlated with reduced culture OD in the plateau phase. Finally, subsequent lowering of antibiotic 2 loading did not impact on bacterial growth anymore. The small inhibition effect was observed only at concentration $64 \mu \mathrm{g} / \mathrm{mL}$ for the compound 2 before the UV-irradiation (Figure 3A), which corresponds to the earlier obtained MIC results. From the obtained result, we have concluded that the starting concentration $32 \mu \mathrm{g} / \mathrm{mL}$ of target cephalosporin derivative $\mathbf{2}$ is optimal to induce the expected difference between "activated" and "nonactivated" forms of antibiotic. 

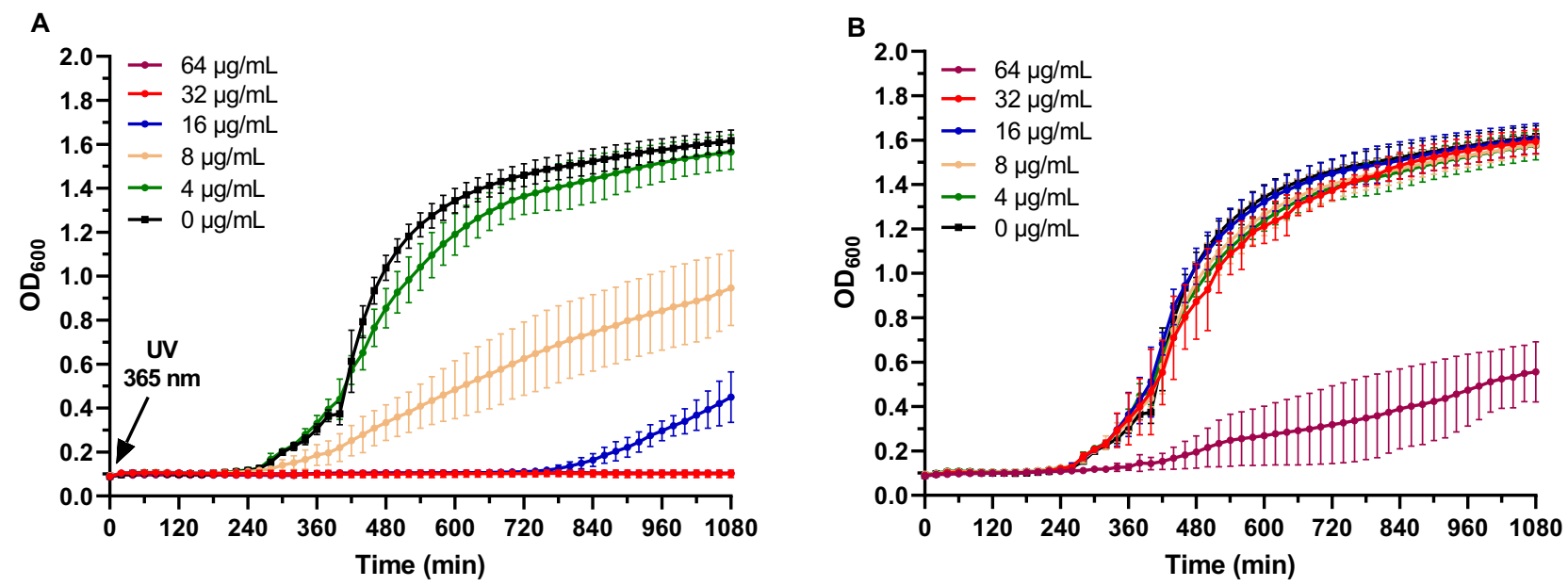

Figure 3. Bacterial growth curves of $P$. aeruginosa ATCC 27853 at decreasing concentrations of the cephalosporin derivative 2. (A) Non-irradiated samples. (B) Sample after irradiation at time $0 \mathrm{~min}$ with UV light at $\lambda=365 \mathrm{~nm}$ for $5 \mathrm{~min}$. All the solutions were irradiated before inoculation. Data points represent mean value $\pm \operatorname{SD}(n=3)$.

Unfortunately, the testing of cephalosporin derivative 2 against Gram-positive strains yielded disappointing results, with a no difference in growth evident before and after UV-irradiation. However, this lack of difference might be due to a small or non-existent gap in activity between "non-active" and "active" forms of cephalosporin derivative against $B$. subtilis and $S$. aureus.

Next, to show the absence of activity coming from the released by-product after the UV-irradiation of designed antibiotics 1 and 2, a control experiment was carried out. The linkers 9a and 12a in the highest concentration of 64 $\mu \mathrm{g} / \mathrm{mL}$ were UV-irradiated at $\lambda=365 \mathrm{~nm}$ for $5 \mathrm{~min}$ and inoculated with bacteria. The time-resolved bacterial growth analysis was repeated during $18 \mathrm{~h}$ at $37{ }^{\circ} \mathrm{C}$. Gratifyingly, no inhibitory effect was observed for both linkers 9a and 12a against Gram-positive and Gram-negative strains, respectively (Figures S9-S10).

In order to demonstrate the benefit of our designed antibiotics $\mathbf{1}$ and $\mathbf{2}$, the study of their effect after UV-irradiation was carried out in the exponential phase of bacterial growth. The bacteria were incubated with compounds $\mathbf{1}$ or $\mathbf{2}$ for $7 \mathrm{~h}$, whereafter the solutions were exposed to UV light at $\lambda=365 \mathrm{~nm}$ for $5 \mathrm{~min}$. The dynamic growth analysis was recorded during $18 \mathrm{~h}$ in total. As shown in Figure 4, the clear inhibition of the bacterial growth was observed for Gram-positive B. subtilis (A) and VSSA (B) after the release of vancomycin amide 3, and Gram-negative E. coli (D) in presence of cephalosporin derivative 4 compare to the negative control experiments. The concentration of the compound 1 used to inhibit $B$. subtilis growth was 2 times higher $(2 \mu \mathrm{g} / \mathrm{mL})$ compared to the experiment with irradiation at $\mathrm{t}=0 \mathrm{~min}$, which was not the case for the other strains. This can be explained by the insufficient amount of antibiotic released at a lower loading concentration to kill a large number of bacteria formed after 7 hours of incubation. Concerning MRSA and P. aeruginosa, a slowdown in bacterial growth has been detected after UV- 
212 irradiation of antibiotics 1 and 2, respectively (Figure 4C and 4E). It was also demonstrated that the bacteria was not

213 affected by the UV-irradiation step as the control experiment did not exhibit any deviations in growth.

A

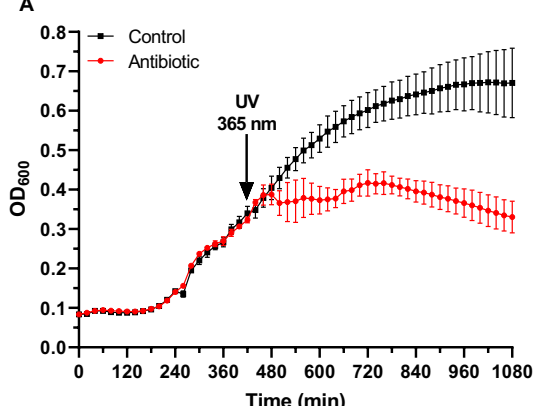

D

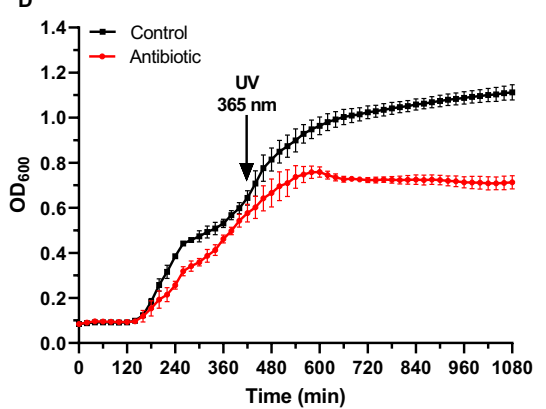

B

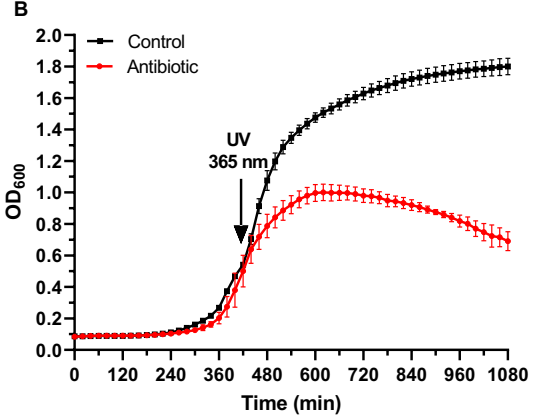

E

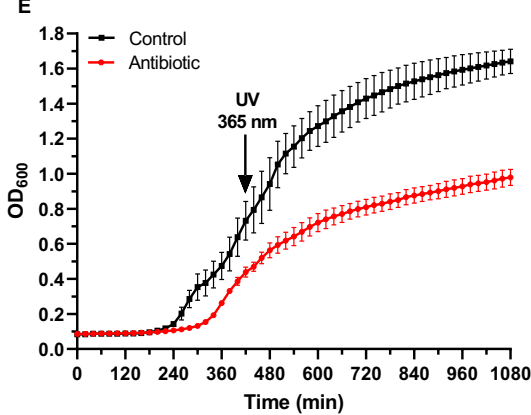

c

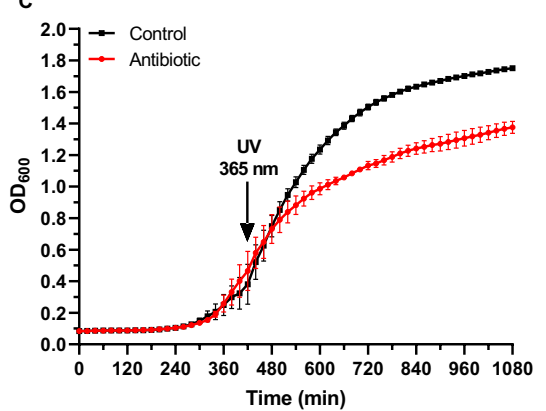

215

216

217

218

219

220

221

222

223

224

225

226

227

228

229

230

231

232

233

Figure 4. Bacterial growth in presence of modified antibiotics with UV-irradiation step after 7 h of bacterial growth for $5 \mathrm{~min}$ at $365 \mathrm{~nm}$. (A) B. subtilis ATCC 6633 mixed with vancomycin derivative $1(2 \mu \mathrm{g} / \mathrm{mL})$ (B) S. aureus ATCC 29213 mixed with vancomycin derivative $1(4 \mu \mathrm{g} / \mathrm{mL})$ (C) S. aureus ATCC 43300 mixed with vancomycin derivative $1(4 \mu \mathrm{g} / \mathrm{mL})$ (D) E. coli mixed with cephalosporin derivative $2(4 \mu \mathrm{g} / \mathrm{mL})$ (E) P. aeruginosa ATCC 27853 mixed with cephalosporin derivative 2 (32 $\mu \mathrm{g} / \mathrm{mL})$. Data points represent mean values $\pm \mathrm{SD}(\mathrm{n}=3)$.

The use of photoswitching groups in antibiotics remains challenging for retaining the desired biological effect for a long time. Thermal isomerization of these antibiotics over time led to a loss in activity, as shown by group of Feringa. ${ }^{15}$ For long-term maintenance of the therapeutic effect, irreversible antibiotic release thereby constitutes an advantage. We could successfully demonstrate the remaining antibacterial effect after the activation of the designed compounds over a period of $18 \mathrm{~h}$. Moreover, the loading concentration of target antibiotics required to observe the desired inhibition after UV-irradiation remained low and can be predicted accurately from the MIC results and photocleavage efficacy. However, the initial concentration of the "caged" derivative has to be correlated with the starting amount of bacteria. This tendency was observed for antibiotic 1 tested against $S$. aureus, when $2 \mu \mathrm{g} / \mathrm{mL}$ of vancomycin derivative $\mathbf{1}$ was not sufficient to inhibit bacterial growth after the release of the active drug $\mathbf{3}$, as the bacterial density used for the experiment was 200 times higher compared to MIC test. Additionally, the prolonged $\log$ phase in case of $P$. aeruginosa in presence of $16 \mu \mathrm{g} / \mathrm{mL}$ of cephalosporin 2 reveal the importance to use the higher concentration of antibiotic to observe full inhibitory effect. This delay in bacterial growth in presence of insufficient amount of antibiotic was earlier showed by the group of Bunge studying Enterococcus faecium. ${ }^{59}$ Another advantage of the system reported herein is that by small changes in initial antibiotic structure, we retained the biological activity against a broader spectrum of bacterial strains. The small difference in activity was observed for cephalosporin derivative, however, it could be readily improved by the introduction of longer PEG chains. 
238 In summary, we have developed a new and efficient PEGylation approach for the caging of antibiotic activity. In this

239 report, we applied photo modifications for UV light-stimulated control of the activity of two broadly used antibiotics 240 vancomycin and cephalosporin. The modified antibiotics could be irreversibly turned into an active form using an 241 external stimulus. The release experiments performed in presence of Gram-negative and Gram-positive strains growth phases. In principle, the developed approach could be applied to any antibiotic possessing active groups for the modification, opening the field of photopharmacology without the need for dramatic changes in a drug structure.

\section{METHODS}

Chemistry. General. Reactions were carried out under inert gas $\left(\mathrm{N}_{2}\right.$ or $\left.\mathrm{Ar}\right)$ in oven-dried $\left(120^{\circ} \mathrm{C}\right)$ glass equipment and monitored for completion by TLC or UHPLC-MS (ESI). Solvents for reactions and analyses were of analytical grade. Fmoc-photo-linker 7, $\mathrm{NH}_{2} \mathrm{C}_{2} \mathrm{H}_{4} \mathrm{PEG}_{23} \mathrm{OMe}$ (m- $\mathrm{PEG}_{24}$-amine), 5-Hydroxy-2-nitrobenzaldehyde 10, and 1bromo-2-(2-methoxyethoxy)ethane was purchased from Iris biotech, BroadPharm, FluoroChem and Sigma-Aldrich, respectively. The synthesis of compounds $\mathbf{1 1 b}$ and $\mathbf{1 4}$ have already been reported. ${ }^{60,61}$ Analytical thin-layer chromatography (TLC) was run on Merck TLC plates silica gel 60 F254 on glass plate with the indicated solvent system; the spots were visualized by UV light $(365 \mathrm{~nm})$, and stained by anisaldehyde, ninhydrin, or $\mathrm{KMnO}_{4}$ stain. Silica gel column chromatography was performed using silica gel 60 (230 - 400 Mesh) purchased from SigmaAldrich with the solvent mixture indicated. The SPE columns used were DSC-18 (Supelco, Sigma). Preparative HPLC separations were performed on a Shimadzu HPLC system (LC-20AP dual pump, CBM-20A Communication Bus Module, SPP-20, A UV/VIS Detector, FRC-10A Fraction collector) using reverse-phase (RP) columns GeminiNX C18 (250 mm x 21.2 mm; $10 \mu \mathrm{m}, 110 \AA \AA)$ or Synergi Hydro-RP (250 mm x 21.2 mm; $10 \mu \mathrm{m}, 80 \AA)$. Ultra-highperformance liquid chromatography (UHPLC) coupled to mass spectrometer (MS) experiments were performed on an Ultimate 3000 LC system (HPG-3400 RS pump, WPS-3000 TRS autosampler, TCC-3000 RS column oven, Vanquish DAD detector from Thermo Scientific) coupled to a triple quadrupole (TSQ Quantum Ultra from Thermo Scientific). The separation was performed using a RP column (Kinetex EVO C18; 50×2.1 mm; $1.7 \mu \mathrm{m} ; 100 \AA$, Phenomenex), a flow of $0.4 \mathrm{ml} / \mathrm{min}$, a solvent system composed of $\mathrm{A}\left(\mathrm{H}_{2} \mathrm{O}+0.1 \% \mathrm{HCO}_{2} \mathrm{H}\right)$ and $\mathrm{B}(\mathrm{MeCN}+0.1 \%$ $\mathrm{HCO}_{2} \mathrm{H}$ ) and an elution gradient starting with $5 \% \mathrm{~B}$, increasing from $5 \%$ to $95 \% \mathrm{~B}$ in $3.5 \mathrm{~min}$, from $95 \%$ to $100 \% \mathrm{~B}$ in $0.05 \mathrm{~min}$, and washing the column with $100 \% \mathrm{~B}$ for $1.25 \mathrm{~min}$. UHPLC-MS measurements after the photolysis experiments the fragments ions were monitored by SIM mode focusing on the $\mathrm{m} / z$ 505.7 $\mathrm{Da}$ and $656.8 \mathrm{Da}$. IRspectroscopy was performed on a Varian 800 FT-IR ATR Spectrometer. Lyophilization was performed on a Christ Freeze dryer ALPHA 1-4 LD plus. High-resolution electrospray mass spectra (HR-ESI-MS) were recorded on a timsTOF Pro TIMS-QTOF-MS instrument (Bruker Daltonics GmbH, Bremen, Germany). The samples were dissolved in (e.g. $\mathrm{MeOH})$ at a concentration of ca. $50 \mu \mathrm{g} / \mathrm{ml}$ and analyzed via continuous flow injection $(2 \mu \mathrm{L} / \mathrm{min})$. The mass spectrometer was operated in the positive (or negative) electrospray ionization mode at 4'000 V (-4'000 V) capillary voltage and $-500 \mathrm{~V}(500 \mathrm{~V})$ endplate offset with a $\mathrm{N}_{2}$ nebulizer pressure of 0.4 bar and a dry gas flow of $4 \mathrm{l} / \mathrm{min}$ at $180^{\circ} \mathrm{C}$. Mass spectra were acquired in a mass range from $\mathrm{m} / \mathrm{z} 50$ to $2^{\prime} 000$ at ca. $20^{\prime} 000$ resolution $(\mathrm{m} / \mathrm{z}$ 
622 ) and at $1.0 \mathrm{~Hz}$ rate. The mass analyzer was calibrated between m/z 118 and 2'721 using an Agilent ESI-L low concentration tuning mix solution (Agilent, USA) at a resolution of 20'000 giving a mass accuracy below $2 \mathrm{ppm}$. All solvents used were purchased in best LC-MS quality ${ }^{1} \mathrm{H}$ and $13 \mathrm{C}$ NMR spectra were recorded on Avance II or III500 (500 MHz with Cryo-BBO, TXI, BBI or BBO probes). Chemical shifts are given in parts per million (ppm) on the delta $(\delta)$ scale and coupling constants $(\mathrm{J})$ were reported in Hz. Chemical shifts were calibrated according to the used solvents. $^{62}$

(9H-fluoren-9-yl)methyl(1-(5-methoxy-2-nitro-4-((75-oxo-2,5,8,11,14,17,20,23,26,29,32,35,38,41,44,47, 50,53,56,59, 62,65,68,71-tetracosaoxa-74-azaoctaheptacontan-78-yl) oxy)phenyl)ethyl)carbamate (8a).

To a solution of Fmoc-photo-linker $7(17.4 \mu \mathrm{g}, 0.034 \mathrm{mmol})$ in anhydrous DMF $(0.350 \mathrm{~mL})$ at $0^{\circ} \mathrm{C}$, distilled $N, N$ diisopropylethylamine $(0.017 \mathrm{ml}, 0.1 \mathrm{mmol})$ and HATU $(25.4 \mathrm{mg}, 0.067 \mathrm{mmol})$ were added. The reaction mixture turned dark brown. $m$-PEG24-amine $(40 \mu \mathrm{g}, 0.037 \mathrm{mmol})$ was added after $10 \mathrm{~min}$. The reaction was stirred at $0^{\circ} \mathrm{C}$ for $1 \mathrm{~h}$ and then at $\mathrm{rt}$ for $1 \mathrm{~h}$. The solvents were evaporated followed by purification of crude product by flash silica column chromatography, (DCM:MeOH 100:5) to obtain the product $8 \mathbf{a}(38 \mu \mathrm{g}, 0.033 \mathrm{mmol}, 72 \%)$ as a slightly yellow oil.

$\mathbf{R}_{f}=0.29$ (DCM:MeOH 100:5); ${ }^{1} \mathbf{H}$ NMR (500 MHz, Chloroform- $d$ ) $\delta 7.82-7.69(\mathrm{~m}, 2 \mathrm{H}), 7.58-7.54(\mathrm{~m}, 3 \mathrm{H})$, $7.45-7.34(\mathrm{~m}, 3 \mathrm{H}), 7.33-7.27(\mathrm{~m}, 2 \mathrm{H}), 6.88(\mathrm{~s}, 1 \mathrm{H}), 6.49-6.45(\mathrm{~m}, 1 \mathrm{H}), 5.60-5.49(\mathrm{~m}, 1 \mathrm{H}), 5.40-5.36(\mathrm{~m}$, $1 \mathrm{H}), 4.45-4.32(\mathrm{~m}, 1 \mathrm{H}), 4.17(\mathrm{~s}, 1 \mathrm{H}), 4.13-4.08(\mathrm{~m}, 2 \mathrm{H}), 3.88(\mathrm{~s}, 3 \mathrm{H}), 3.74-3.57(\mathrm{~m}, 121 \mathrm{H}), 3.57-3.51(\mathrm{~m}, 6 \mathrm{H})$, $3.48-3.42(\mathrm{~m}, 4 \mathrm{H}), 3.37(\mathrm{~s}, 3 \mathrm{H}), 2.45-2.35(\mathrm{~m}, 3 \mathrm{H}), 2.22-2.15(\mathrm{~m}, 2 \mathrm{H}), 2.07-1.82(\mathrm{~m}, 6 \mathrm{H}), 1.60-1.39(\mathrm{~m}$, 4H). ${ }^{13} \mathbf{C}$ NMR $\left(126 \mathrm{MHz}, \mathrm{CDCl}_{3}\right) \delta 172.23,155.57,153.96,147.18,143.98,141.43,140.56,134.43,127.81,127.13$, $125.03,120.09,109.99,72.06,70.69,70.30,70.05,68.72$, 66.65, 59.16, 56.47, 48.60, 47.35, 39.38, 32.65, 25.03, 21.81. IR (film): $v_{\max }=2872,1719,1648,1519,1452,1349,1272,1247,1217,1182,1096,948,836,762,742 \mathrm{~cm}^{-}$ ${ }^{1}$; ESI-HRMS: calcd for $\mathrm{C}_{77} \mathrm{H}_{127} \mathrm{O}_{31} \mathrm{~N}_{3} \mathrm{Na}[\mathrm{M}+\mathrm{Na}]^{+}, m / z=1612.83457 \mathrm{Da}$, found $1612.83540 \mathrm{Da}$.

Methyl 4-(4-(1-((((9H-fluoren-9-yl)methoxy) carbonyl) amino)ethyl)-2-methoxy-5-nitrophenoxy)butanoate (8b) Fmoc-photo-linker 7 (50 mg, $0.096 \mathrm{mmol})$ was dissolved in $\mathrm{MeOH}(0.9 \mathrm{~mL})$. Sulfuric acid (3 drops) was added to the reaction mixture and the mixture was stirred overnight at $50{ }^{\circ} \mathrm{C}$. The solvent was removed under reduced pressure and DCM was added to the reaction mixture. The formed precipitate was filtered off and the solution was concentrated to afford the desired product $\mathbf{8 b}$ as a white solid (49 $\mathrm{mg}, 0.096 \mathrm{mmol}, 97 \%) .{ }^{1} \mathbf{H} \mathbf{~ N M R}(500 \mathrm{MHz}$, DMSO- $\left.d_{6}\right) \delta 8.02(\mathrm{~d}, J=8.0 \mathrm{~Hz}, 1 \mathrm{H}), 7.87(\mathrm{~d}, J=7.2 \mathrm{~Hz}, 2 \mathrm{H}), 7.64(\mathrm{~d}, J=7.2 \mathrm{~Hz}, 2 \mathrm{H}), 7.49-7.47$ (m, 1H), $7.42-$ $7.38(\mathrm{~m}, 2 \mathrm{H}), 7.32-7.26(\mathrm{~m}, 2 \mathrm{H}), 7.25(\mathrm{~s}, 1 \mathrm{H}), 5.21(\mathrm{p}, J=7.0 \mathrm{~Hz}, 1 \mathrm{H}), 4.33-4.23(\mathrm{~m}, 2 \mathrm{H}), 4.20-4.15(\mathrm{~m}, 1 \mathrm{H})$, $4.06(\mathrm{t}, J=6.1 \mathrm{~Hz}, 3 \mathrm{H}), 3.86(\mathrm{~s}, 3 \mathrm{H}), 3.60(\mathrm{~s}, 3 \mathrm{H}), 2.47$ (t, $J=7.2 \mathrm{~Hz}, 2 \mathrm{H}), 2.04-1.92(\mathrm{~m}, 2 \mathrm{H}), 1.41(\mathrm{~d}, J=6.7 \mathrm{~Hz}$, 3H). ${ }^{13} \mathrm{C}$ NMR (126 MHz, DMSO) $\delta 172.88,155.25,153.40,146.23,143.89,143.61,140.73,139.92,135.47,127.59$, $126.90,125.00,120.10,109.37,108.16,67.78,65.21,56.19,51.35,46.68,45.93,29.82,23.97,21.89$. $\mathbf{R}_{f}=0.9$ (DCM/MeOH 20:1). IR (film): 3348, 2938, 1736, 1687, 1579, 1451, 1375, 1335, 1278, 1254, 1218, 1178, 1119 , 1086, 1070, 1051, 1021, 876, 758, 738, 646. HR-ESI-MS (MeOH): calcd for $\mathrm{C}_{29} \mathrm{H}_{30} \mathrm{O}_{8} \mathrm{~N}_{2} \mathrm{Na}[\mathrm{M}+\mathrm{Na}], m / z=$ 557.18944 , found 557.18952 .

Compounds 9a and 9b. General procedure. Compound $8 \mathbf{a}$ or $8 \mathbf{b}$ was treated with a solution of piperidine in DMF $(20 \% \mathrm{v} / \mathrm{v}, 0.01 \mathrm{mM}$ solution). The reaction mixture was stirred for $1-2 \mathrm{~h}$. The solvent was evaporated and the 
remaining reaction mixture was washed with ether $(2 \times 10 \mathrm{~mL})$ to afford the desired products. Analytical data and yields for obtained compounds are described below.

4-(4-(1-aminoethyl)-2-methoxy-5-nitrophenoxy)-N-(2,5,8,11,14,17,20,23,26,29,32,35,38,41,44,47,50,

\section{3,56,59,62,65,68,71-tetracosaoxatriheptacontan-73-yl)butanamide (9a)}

The product was obtained as a slightly yellow oil ( $24 \mu \mathrm{g}, 0.020 \mathrm{mmol}, 87 \%) .{ }^{1} \mathbf{H}$ NMR $\left(500 \mathrm{MHz}, \mathrm{DMSO}-d_{6}\right) \delta 8.27$ (s, 1H), $7.92(\mathrm{t}, J=5.5 \mathrm{~Hz}, 1 \mathrm{H}), 7.49-7.42(\mathrm{~m}, 2 \mathrm{H}), 4.02(\mathrm{t}, J=6.4 \mathrm{~Hz}, 2 \mathrm{H}), 3.91(\mathrm{~s}, 3 \mathrm{H}), 3.66-3.61(\mathrm{~m}, 2 \mathrm{H}), 3.60$ $-3.44(\mathrm{~m}, 121 \mathrm{H}), 3.44-3.34(\mathrm{~m}, 12 \mathrm{H}), 3.24(\mathrm{~s}, 3 \mathrm{H}), 3.20(\mathrm{q}, J=5.8 \mathrm{~Hz}, 2 \mathrm{H}), 2.24(\mathrm{t}, J=7.4 \mathrm{~Hz}, 2 \mathrm{H}), 1.93(\mathrm{p}, J=$ $6.8 \mathrm{~Hz}, 2 \mathrm{H}), 1.35$ (d, $J=6.1 \mathrm{~Hz}, 3 \mathrm{H}) .{ }^{13} \mathbf{C}$ NMR (126 MHz, DMSO) $\delta 171.50,153.17,146.22,140.13,109.75$, 108.38, 71.28, 69.78, 69.72, 69.58, 69.56, 69.11, 68.26, 58.05, 56.19, 38.52, 31.47, 24.65. ESI-HRMS: calcd for $\mathrm{C}_{62} \mathrm{H}_{118} \mathrm{O}_{29} \mathrm{~N}_{3}[\mathrm{M}+\mathrm{H}]^{+}, m / z=1368.78455 \mathrm{Da}$, found $1368.78635 \mathrm{Da}$.

Methyl 4-(4-(1-aminoethyl)-2-methoxy-5-nitrophenoxy)butanoate (9b)

The product was obtained as a slightly yellow amorphous solid (10 mg, $0.044 \mathrm{mmol}, 73 \%)$. $\mathbf{R}_{\boldsymbol{f}}=0.45(\mathrm{DCM} / \mathrm{MeOH}$ 15:1). ${ }^{1} \mathbf{H}$ NMR (500 MHz, $\left.\mathrm{CDCl}_{3}\right) \delta 7.47$ (s, 1H), 7.31 (s, 1H), 4.79 (q, $\left.J=6.5,2 \mathrm{H}\right), 4.09$ (t, $\left.J=6.4,2 \mathrm{H}\right), 3.96$ (s, 3H), $3.69(\mathrm{~s}, 3 \mathrm{H}), 2.55(\mathrm{t}, J=7.3 \mathrm{~Hz}, 2 \mathrm{H}), 2.21-2.14(\mathrm{~m}, 2 \mathrm{H}), 1.62(\mathrm{~s}, 3 \mathrm{H}), 1.42(\mathrm{~d}, J=6.5 \mathrm{~Hz}, 3 \mathrm{H}) .{ }^{13} \mathbf{C}$ NMR $(126$ $\left.\mathrm{MHz}_{\mathrm{CDCl}}\right) \delta 173.51,153.89,146.69,140.85,137.72,109.25,109.06,68.34,56.42,51.86,46.02,30.52,24.91$, 24.42. IR (film): 2954, 1735, 1577, 1516, 1442, 1333, 1272, 1210, 1174, 1052, 818, 759; HR-ESI-MS: calcd for $\mathrm{C}_{14} \mathrm{H}_{21} \mathrm{O}_{6} \mathrm{~N}_{2}[\mathrm{M}+\mathrm{H}], m / z=313.13941$, found 313.13930.

Compounds 1 and 5. General procedure. Vancomycin hydrochloride (1 eq.), PyBoP (3 eq.) and HOBt (1 eq.) were dissolved in dry DMF $(0.05 \mathrm{mM}$, based on vancomycin). To the reaction mixture freshly distilled $N, N$ diisopropylethylamine ( 3 eq.) was added followed by the addition of linker 9 or 16 (1.1 eq.). The reaction mixture was stirred for $1 \mathrm{~h}$ at $\mathrm{rt}$ and the solvent was evaporated. The mixture was dissolved in $\mathrm{MeCN}: \mathrm{H}_{2} \mathrm{O}(1: 1$, with $0.1 \%$ $\mathrm{HCO}_{2} \mathrm{H}$ ) and filtered through a SPE column. The solvent was evaporated and the compound was purified by preparative RP-HPLC. The purification methods, analytical data, and yields are shown below.

Vancomycin derivative with $P E G_{24}$ linker (1)

RP-HPLC: Gradient 5\% B for $14 \mathrm{~min}$; 5\% - 40\% B for $36 \mathrm{~min}$; 40\% - 100\% B for $2 \mathrm{~min}$, wash. The desired product, eluting at $28.2 \mathrm{~min}$, was collected and lyophilized to afford product $1(3.1 \mathrm{mg}, 0.008 \mathrm{mmol}, 28 \%)$ as a white solid.

${ }^{1}$ H NMR $\left(500 \mathrm{MHz}\right.$, Methanol- $\left.d_{4}\right) \delta 8.48(\mathrm{~s}, 1 \mathrm{H}), 7.68-7.63(\mathrm{~m}, 1 \mathrm{H}), 7.61(\mathrm{~s}, 2 \mathrm{H}), 7.24(\mathrm{~d}, J=8.0 \mathrm{~Hz}, 1 \mathrm{H}), 7.04$ $(\mathrm{d}, J=2.0 \mathrm{~Hz}, 1 \mathrm{H}), 6.96(\mathrm{~s}, 1 \mathrm{H}), 6.86(\mathrm{~d}, J=8.6 \mathrm{~Hz}, 1 \mathrm{H}), 6.43(\mathrm{~d}, J=2.3 \mathrm{~Hz}, 1 \mathrm{H}), 5.93-5.88(\mathrm{~m}, 1 \mathrm{H}), 5.69(\mathrm{q}, J=$ $6.9 \mathrm{~Hz}, 1 \mathrm{H}), 5.48-5.44(\mathrm{~m}, 1 \mathrm{H}), 5.42(\mathrm{~d}, J=3.7 \mathrm{~Hz}, 1 \mathrm{H}), 5.38-5.28(\mathrm{~m}, 1 \mathrm{H}), 4.63-4.58(\mathrm{~m}, 1 \mathrm{H}), 4.16-4.09(\mathrm{~m}$, $2 \mathrm{H}), 3.88-3.83(\mathrm{~m}, 1 \mathrm{H}), 3.81(\mathrm{~s}, 2 \mathrm{H}), 3.78-3.72(\mathrm{~m}, 1 \mathrm{H}), 3.70-3.58(\mathrm{~m}, 95 \mathrm{H}), 3.58-3.51(\mathrm{~m}, 6 \mathrm{H}), 3.51-3.47$ $(\mathrm{m}, 1 \mathrm{H}), 3.39(\mathrm{t}, J=5.4 \mathrm{~Hz}, 3 \mathrm{H}), 3.36(\mathrm{~s}, 3 \mathrm{H}), 2.87-2.79(\mathrm{~m}, 1 \mathrm{H}), 2.53(\mathrm{~s}, 3 \mathrm{H}), 2.45(\mathrm{~d}, J=7.6 \mathrm{~Hz}, 2 \mathrm{H}), 2.14(\mathrm{p}, J$ $=6.7 \mathrm{~Hz}, 2 \mathrm{H}), 2.05(\mathrm{dd}, J=4.1,13.3 \mathrm{~Hz}, 1 \mathrm{H}), 1.93(\mathrm{~d}, J=13.3 \mathrm{~Hz}, 1 \mathrm{H}), 1.76(\mathrm{p}, J=6.7 \mathrm{~Hz}, 1 \mathrm{H}), 1.71-1.68(\mathrm{~m}$, $1 \mathrm{H}), 1.58(\mathrm{q}, J=6.9 \mathrm{~Hz}, 1 \mathrm{H}), 1.52(\mathrm{~d}, J=6.9 \mathrm{~Hz}, 3 \mathrm{H}), 1.47(\mathrm{~s}, 3 \mathrm{H}), 1.20(\mathrm{~d}, J=6.4 \mathrm{~Hz}, 3 \mathrm{H}), 0.98(\mathrm{~d}, J=6.4 \mathrm{~Hz}$, $3 \mathrm{H}), 0.95\left(\mathrm{~d}, J=6.4 \mathrm{~Hz}, 3 \mathrm{H}\right.$ ). HR-ESI-MS (water): calcd for $\mathrm{C}_{128} \mathrm{H}_{192} \mathrm{O}_{52} \mathrm{~N}_{12} \mathrm{Cl}_{2}[\mathrm{M}+2 \mathrm{H}]^{2+}, m / z=1399.60573$, found 1399.60396. The purity of the compound was analyzed by UHPLC. Gradient starts from 5\% B, 5\% - 95\% B for 3.5 $\min ; 95 \%-100 \%$ for $0.05 \mathrm{~min}$, wash. The product 1 was eluted at $2.02 \mathrm{~min}$ and was detected at $270 \mathrm{~nm}$ 
Vancomycin derivative with photo linker (5)

RP-HPLC: Gradient 5\% B for $14 \mathrm{~min}$; 5\% - 30\% B for $46 \mathrm{~min}$; 30\% - 100\% B for $4 \mathrm{~min}$, wash. The desired product, eluting at $34.4 \mathrm{~min}$, was collected and lyophilized to afford product $5(12.3 \mathrm{mg}, 0.023 \mathrm{mmol}, 30 \%)$ as a slightly yellowish solid.

${ }^{1}$ H NMR $\left(500 \mathrm{MHz}\right.$, Methanol- $\left.d_{4}\right) \delta 8.50(\mathrm{~s}, 1 \mathrm{H}), 7.65-7.62(\mathrm{~m}, 1 \mathrm{H}), 7.61-7.58(\mathrm{~m}, 2 \mathrm{H}), 7.58-7.53(\mathrm{~m}, 1 \mathrm{H})$, $7.24(\mathrm{~d}, J=8.4 \mathrm{~Hz}, 1 \mathrm{H}), 7.03(\mathrm{~d}, J=2.2 \mathrm{~Hz}, 1 \mathrm{H}), 7.02-6.98(\mathrm{~m}, 1 \mathrm{H}), 6.95(\mathrm{~s}, 1 \mathrm{H}), 6.86(\mathrm{~d}, J=8.6 \mathrm{~Hz}, 1 \mathrm{H}), 6.42$ $(\mathrm{d}, J=2.3 \mathrm{~Hz}, 1 \mathrm{H}), 5.90(\mathrm{~d}, J=2.0 \mathrm{~Hz}, 1 \mathrm{H}), 5.79-5.76(\mathrm{~m}, 1 \mathrm{H}), 5.70(\mathrm{q}, J=6.9 \mathrm{~Hz}, 1 \mathrm{H}), 5.45(\mathrm{~d}, J=7.5 \mathrm{~Hz}, 1 \mathrm{H})$, $5.42(\mathrm{~d}, J=4.2 \mathrm{~Hz}, 1 \mathrm{H}), 5.38-5.32(\mathrm{~m}, 1 \mathrm{H}), 5.31-5.28(\mathrm{~m}, 1 \mathrm{H}), 4.19-4.16(\mathrm{~m}, 1 \mathrm{H}), 4.15-4.10(\mathrm{~m}, 2 \mathrm{H}), 3.87-$ $3.83(\mathrm{~m}, 2 \mathrm{H}), 3.80(\mathrm{~s}, 3 \mathrm{H}), 3.77-3.71(\mathrm{~m}, 1 \mathrm{H}), 3.70(\mathrm{~s}, 2 \mathrm{H}), 3.55-3.50(\mathrm{~m}, 1 \mathrm{H}), 3.42-3.36(\mathrm{~m}, 1 \mathrm{H}), 2.82(\mathrm{dd}, J=$ 2.6, 16.1 Hz, 1H), 2.57 (t, $J=7.4 \mathrm{~Hz}, 2 \mathrm{H}), 2.48(\mathrm{~s}, 3 \mathrm{H}), 2.35-2.37(\mathrm{~m}, 1 \mathrm{H}), 2.13(\mathrm{p}, J=6.6 \mathrm{~Hz}, 2 \mathrm{H}), 2.08-2.02$ $(\mathrm{m}, 1 \mathrm{H}), 1.92(\mathrm{~d}, J=13.7 \mathrm{~Hz}, 1 \mathrm{H}), 1.81-1.74(\mathrm{~m}, 1 \mathrm{H}), 1.68-1.61(\mathrm{~m}, 1 \mathrm{H}), 1.58-1.54(\mathrm{~m}, 1 \mathrm{H}), 1.54-1.49(\mathrm{~m}$, 3H), 1.47 (s, 3H), 1.20 (d, $J=6.4 \mathrm{~Hz}, 3 \mathrm{H}), 0.98$ (d, $J=6.4 \mathrm{~Hz}, 3 \mathrm{H}), 0.95$ (d, $J=6.4 \mathrm{~Hz}, 3 \mathrm{H})$. HR-ESI-MS (water): calcd for $\mathrm{C}_{80} \mathrm{H}_{95} \mathrm{O}_{29} \mathrm{~N}_{11} \mathrm{C}_{12}[\mathrm{M}+2 \mathrm{H}]^{2+}, m / z=871.78316$, found 871.78295 . The purity of the compound was analyzed by UHPLC. Gradient starts from 5\% B, 5\% - 95\% B for $3.5 \mathrm{~min}$; 95\% - 100\% for $0.05 \mathrm{~min}$, wash. The product 5 was eluted at $2.11 \mathrm{~min}$ and was detected at $270 \mathrm{~nm}$.

\section{5-(2-(2-methoxyethoxy)ethoxy)-2-nitrobenzaldehyde (11a)}

5-Hydroxy-2-nitrobenzaldehyde 10 (100 mg, $0.598 \mathrm{mmol})$ was dissolved in dry DMF (6 mL) and powdered $\mathrm{K}_{2} \mathrm{CO}_{3}$ (99 mg, $0.718 \mathrm{mmol})$ was added. After $5 \mathrm{~min}$ 1-bromo-2-(2-methoxyethoxy)ethane $(0.090 \mathrm{~mL}, 0.658 \mathrm{mmol})$ was added dropwise and the reaction mixture was stirred at $90{ }^{\circ} \mathrm{C}$ overnight. Then, the mixture was cooled to rt, diluted with $\mathrm{H}_{2} \mathrm{O}$, and extracted with DCM $(3 \times 30 \mathrm{~mL})$. The combined organic phases were washed with brine, dried over $\mathrm{Na}_{2} \mathrm{SO}_{4}$ and concentrated under reduced pressure. The crude was purified by column chromatography $(n-$ pentane:EtOAc 2:1) to afford the desire product 11a as yellow oil (158 mg, $0.598 \mathrm{mmol}, 98 \%)$. $\mathbf{R}_{\boldsymbol{f}}(n$-pentane:EtOAc 2:1) $=0.3 .{ }^{1} \mathbf{H}$ NMR $\left(400 \mathrm{MHz}, \mathrm{CDCl}_{3}\right) \delta 10.47(\mathrm{~s}, 1 \mathrm{H}), 8.15(\mathrm{~d}, J=9.1 \mathrm{~Hz}, 1 \mathrm{H}), 7.34(\mathrm{~d}, J=2.9 \mathrm{~Hz}, 1 \mathrm{H}), 7.18(\mathrm{dd}$, $J=9.1,2.9 \mathrm{~Hz}, 1 \mathrm{H}), 4.30-4.25(\mathrm{~m}, 2 \mathrm{H}), 3.92-3.86(\mathrm{~m}, 2 \mathrm{H}), 3.74-3.69(\mathrm{~m}, 2 \mathrm{H}), 3.59-3.55(\mathrm{~m}, 2 \mathrm{H}), 3.38(\mathrm{~s}$, 3H). ${ }^{13}$ C NMR (101 MHz, $\left.\mathrm{CDCl}_{3}\right) \delta 188.60,163.44,142.48,134.40,127.36,119.26,114.06,72.04,71.04,69.42$, 68.78, 59.25. IR (film): 2881, 1695, 1583, 1516, 1485, 1425, 1389, 1329, 1288, 1246, 1234, 1199, 1164, 1108, 1074, 1048, 934, 886, 846, 746, 676, 631. HRMS (ESI): calcd for $\mathrm{C}_{12} \mathrm{H}_{16} \mathrm{O}_{6} \mathrm{~N}[\mathrm{M}+\mathrm{H}]^{+}, m / z=270.09721$, found 270.09718.

Compounds 12a and 12b. General procedure. In a flask covered with aluminum foil, $\mathrm{NaBH}(\mathrm{OAc})_{3}(1$ eq. $)$ and molecular sieves $(3 \AA)$ were set under argon and suspended in 1,2-dichloroethane (0.2 M solution). Then, 4(aminomethyl)pyridine (1.1 eq) was added by syringe, followed by $\mathrm{AcOH}$ (glacial, $0.1 \mathrm{~mL}, 2 \mathrm{mmol}$ ). The reaction mixture was stirred at $\mathrm{rt}$ while a solution of $\mathbf{1 1 a}$ or $\mathbf{1 1 b}(1 \mathrm{eq})$ in dry 1,2-dichloroethane ( $0.2 \mathrm{M}$ solution) was added dropwise by syringe over $10 \mathrm{~min}$. After $3 \mathrm{~h}$ another equivalent of $\mathrm{NaBH}(\mathrm{OAc})_{3}$ was added. The reaction was stirred for additional $2 \mathrm{~h}$ at $\mathrm{rt}$ followed by the addition of one more equivalent of $\mathrm{NaBH}(\mathrm{OAc})_{3}$. After $6 \mathrm{~h}$ in total, the reaction mixture was poured into sat. $\mathrm{NaHCO}_{3}$ solution and extracted with DCM $(3 \times 20 \mathrm{~mL})$. The combined organic phase was washed with brine, dried over $\mathrm{Na}_{2} \mathrm{SO}_{4}$ and the solvent was removed under vacuum. The crude product was purified by column chromatography. The purification methods, analytical data, and yields are shown below. 
N-(5-(2-(2-methoxyethoxy)ethoxy)-2-nitrobenzyl)-1-(pyridin-4-yl)methanamine (12a)

The purification is carried out by column chromatography (DCM:MeOH 20:1) The desired product 12a was obtained as yellow oil (41 mg, $0.186 \mathrm{mmol}, 63 \%) . \boldsymbol{R} \boldsymbol{f}=0.31(\mathrm{DCM} / \mathrm{MeOH} 20: 1) .{ }^{1} \mathbf{H}$ NMR $\left(500 \mathrm{MHz}, \mathrm{DMSO}-d_{6}\right) \delta 8.48(\mathrm{dd}$, $J=4.4,1.6,2 \mathrm{H}), 8.02(\mathrm{~d}, J=9.0 \mathrm{~Hz}, 1 \mathrm{H}), 7.36-7.33(\mathrm{~m}, 2 \mathrm{H}), 7.32(\mathrm{~d}, J=2.8 \mathrm{~Hz}, 1 \mathrm{H}), 7.03(\mathrm{dd}, J=9.1,2.8 \mathrm{~Hz}$, $1 \mathrm{H}), 4.25-4.21(\mathrm{~m}, 2 \mathrm{H}), 4.00(\mathrm{~s}, 2 \mathrm{H}), 3.79-3.76(\mathrm{~m}, 2 \mathrm{H}), 3.75(\mathrm{~s}, 2 \mathrm{H}), 3.61-3.58(\mathrm{~m}, 2 \mathrm{H}), 3.47-3.44(\mathrm{~m}, 2 \mathrm{H})$, 3.28 (s, 2H), 3.24 (s, 3H). ${ }^{13}$ C NMR (126 MHz, DMSO) $\delta 162.19,149.32,141.36,127.32,122.80,115.75,112.92$, 71.21, 69.68, 68.57, 67.93, 57.99, 51.08, 49.30. IR (film): 2879, 1603, 1579, 1512, 1453, 1414, 1337, 1287, 1109, 1080, 993, 840. HRMS (ESI): calcd for $\mathrm{C}_{18} \mathrm{H}_{24} \mathrm{O}_{5} \mathrm{~N}_{3}[\mathrm{M}+\mathrm{H}], \mathrm{m} / z=362.17105$ found 362.17078

$N$-(5-(methoxymethoxy)-2-nitrobenzyl)-1-(pyridin-4-yl)methanamine (12b)

The purification is carried out by column chromatography (DCM/MeOH 98:2, 95:5). The desired product 12b was obtained as yellow oil (173 mg, $0.570 \mathrm{mmol}, 48 \%) . \boldsymbol{R} \boldsymbol{f}=0.28(\mathrm{DCM} / \mathrm{MeOH} 95: 5){ }^{1} \mathbf{H}$ NMR $\left(500 \mathrm{MHz}, \mathrm{CDCl}_{3}\right) \delta$ $8.55(\mathrm{~d}, J=4.7,2 \mathrm{H}), 8.07$ (dd, $J=9.1,1.0 \mathrm{~Hz}, 1 \mathrm{H}), 7.33-7.30(\mathrm{~m}, 2 \mathrm{H}), 7.26-7.24(\mathrm{~d}, J=2.6,1 \mathrm{H}), 7.02$ (ddd, $J=$ 9.1, 2.3, 1.0 Hz, 1H), 5.25 (s, 2H), 4.09 (s, 2H), 3.87 (d, $J=2.0 \mathrm{~Hz}, 2 \mathrm{H}), 3.49$ (s, 3H). ${ }^{13} \mathbf{C ~ N M R}\left(126 \mathrm{MHz}, \mathrm{CDCl}_{3}\right)$ $\delta 161.24,149.99,148.91,142.68,138.20,127.92,123.19,118.24,115.02,94.40,56.64,52.15,50.91$. IR (film): 2907, 1603, 1579, 1513, 1485, 1414, 1337, 1249, 1206, 1152, 1089, 1068, 993, 925, 840, 798, 755, 485.HRMS (ESI): calcd for $\mathrm{C}_{15} \mathrm{H}_{18} \mathrm{~N}_{3} \mathrm{O}_{4}[\mathrm{M}+\mathrm{H}]^{+}, m / z=304.12918$, found 304.12899.

Compounds 13a and 13b. General procedure. Compound 12a or 12b was dissolved in dry THF $(0.2 \mathrm{M})$ and TEA ( 2 eq.) was added. $\mathrm{Boc}_{2} \mathrm{O}$ ( 2 eq.) was dissolved in THF ( $0.1 \mathrm{M}$ solution) and added to the solution. The reaction was stirred for 3-4 h. The formation of product was observed by UHPLC. The solvent was removed under reduced pressure. The resulting crude mixture was purified by column chromatography. The purification methods, analytical data, and yields are shown below.

Tert-butyl (5-(2-(2-methoxyethoxy)ethoxy)-2-nitrobenzyl)(pyridin-4-ylmethyl)carbamate (13a)

The purification is carried out by column chromatography (DCM:MeOH 40:1) The desired product 13a was obtained as a dark yellow oil (50 mg, $0.221 \mathrm{mmol}, 49 \%) . \boldsymbol{R} \boldsymbol{f}=0.30(\mathrm{DCM} / \mathrm{MeOH} 40: 1) .{ }^{1} \mathbf{H}$ NMR $\left(500 \mathrm{MHz}, \mathrm{DMSO}-d_{6}\right) \delta$ $8.53(\mathrm{~s}, 2 \mathrm{H}), 8.16-8.10(\mathrm{~m}, 1 \mathrm{H}), 7.24(\mathrm{~s}, 2 \mathrm{H}), 7.09(\mathrm{dd}, J=9.1,2.7 \mathrm{~Hz}, 1 \mathrm{H}), 6.76(\mathrm{~d}, J=2.7 \mathrm{~Hz}, 1 \mathrm{H}), 4.84-4.74$ $(\mathrm{m}, 1 \mathrm{H}), 4.54-4.44(\mathrm{~m}, 1 \mathrm{H}), 4.23-4.16(\mathrm{~m}, 2 \mathrm{H}), 4.12-4.02(\mathrm{~m}, 1 \mathrm{H}), 3.79-3.75(\mathrm{~m}, 2 \mathrm{H}), 3.59(\mathrm{dd}, J=5.8,3.6$ $\mathrm{Hz}, 2 \mathrm{H}), 3.46$ (dd, $J=5.8,3.6 \mathrm{~Hz}, 2 \mathrm{H}), 3.24$ (s, 3H), 1.33 (d, $J=17.2 \mathrm{~Hz}, 9 \mathrm{H}) .{ }^{13} \mathbf{C}$ NMR (126 MHz, DMSO) $\delta$ 162.71, 154.99, 149.67, 140.71, 113.56, 71.23, 69.72, 68.51, 68.07, 58.05, 27.75, 22.78. IR (film): 2961, 1700, 1579, 1516, 1462, 1414, 1337, 1279, 1110, 1071, 993, 841. HRMS (ESI): calcd for $\mathrm{C}_{23} \mathrm{H}_{32} \mathrm{O}_{7} \mathrm{~N}_{3}[\mathrm{M}+\mathrm{H}]^{+}, m / z=462.22348$ found 462.22356 .

\section{Tert-butyl (5-(methoxymethoxy)-2-nitrobenzyl)(pyridin-4-ylmethyl)carbamate (13b)}

The purification is carried out by column chromatography (DCM/MeOH, 95:5) The desired product 13b was obtained as a dark yellow oil (30 mg, $0.072 \mathrm{mmol}, 55 \%) . \boldsymbol{R} \boldsymbol{f}=0.35$ (DCM/MeOH 95:5). ${ }^{1} \mathbf{H}$ NMR (500 MHz, DMSO$\left.d_{6}\right) \delta 8.55-8.48(\mathrm{~m}, 2 \mathrm{H}), 8.09(\mathrm{~d}, J=9.0 \mathrm{~Hz}, 1 \mathrm{H}), 7.23(\mathrm{~d}, J=5.6 \mathrm{~Hz}, 2 \mathrm{H}), 7.13(\mathrm{dd}, J=9.0,2.7 \mathrm{~Hz}, 1 \mathrm{H}), 6.91(\mathrm{~d}, J$ $=2.7 \mathrm{~Hz}, 1 \mathrm{H}), 5.28(\mathrm{~s}, 2 \mathrm{H}), 4.49(\mathrm{~s}, 2 \mathrm{H}), 3.40(\mathrm{~s}, 3 \mathrm{H}), 1.34(\mathrm{~s}, 9 \mathrm{H}) .{ }^{13} \mathbf{C}$ NMR $(126 \mathrm{MHz}, \mathrm{DMSO}) \delta 161.07,154.98$, 149.65, 147.54, 141.41, 137.19, 127.89, 127.73, 121.03, 114.58, 93.93, 79.95, 55.98, 50.01, 48.76, 27.75. IR (film): 
2976, 1696, 1581, 1517, 1482, 1455, 1413, 1338, 1276, 1241, 1206, 1156, 1068, 995, 925, 842, 755. HRMS (ESI): calcd for $\mathrm{C}_{20} \mathrm{H}_{26} \mathrm{~N}_{3} \mathrm{O}_{6}[\mathrm{M}+\mathrm{H}]^{+}, m / z=404.18161$ found 404.18187 .

Cephalosporin derivatives 2, 4, and 6. General procedure. Under an Ar atmosphere, NaI (3 eq.) was added to a mixture of compound $15(1.5 \mathrm{eq})$ in dry acetone $(0.1 \mathrm{M})$. The reaction mixture was stirred at $\mathrm{rt}$ for $40 \mathrm{~min}$. After this time the linker 13a, 4-(aminomethyl)pyridine or 13b (1 eq.) in dry acetone $(0.05 \mathrm{M})$ was added and the reaction was stirred at $\mathrm{rt}$ for $3-4 \mathrm{~h}$. After the reaction was finished, the solvent was evaporated and the mixture was washed with isopropyl ether (IPE, $2 \mathrm{~mL}$ ). The formed precipitate was dissolved in mixture of DCM:anisole:TFA 5:1:1 $(0.1 \mathrm{~mL})$. The reaction mixture was stirred overnight and then IPE $(2 \mathrm{~mL})$ was added into the reaction. The resulting suspension was centrifuged. The supernatant was removed, and the precipitate was washed with IPE two more times. The crude was dissolved in mixture of $\mathrm{MeOH} / \mathrm{H}_{2} \mathrm{O} / \mathrm{CH}_{3} \mathrm{CN}$ filtered through SPE column and purified by RP-HPLC. The purification methods, analytical data, and yields are shown below.

Cephalosporin derivative with $P E G_{2}$ linker (2)

RP-HPLC: Gradient 5\% B for $14 \mathrm{~min}$; 5\% - 45\% B for $56 \mathrm{~min}$; 45\% - 100\% B for $4 \mathrm{~min}$, wash. The desired product, eluting at $31 \mathrm{~min}$, was collected and lyophilized to afford product $2(0.700 \mathrm{mg}, 0.043 \mathrm{mmol}, 2 \%)$ as a slightly yellowish solid. ${ }^{1} \mathbf{H}$ NMR $\left(500 \mathrm{MHz}\right.$, Methanol- $\left.d_{4}\right) \delta 9.05(\mathrm{~d}, J=6.6 \mathrm{~Hz}, 2 \mathrm{H}), 8.44-8.40(\mathrm{~m}, 1 \mathrm{H}), 8.07-8.05(\mathrm{~m}$, 2H), $7.22(\mathrm{~d}, J=2.6 \mathrm{~Hz}, 1 \mathrm{H}), 7.00(\mathrm{dd}, J=9.1,2.6 \mathrm{~Hz}, 1 \mathrm{H}), 5.85(\mathrm{~d}, J=4.9 \mathrm{~Hz}, 1 \mathrm{H}), 5.67(\mathrm{~d}, J=13.8 \mathrm{~Hz}, 1 \mathrm{H}), 5.20$ $-5.13(\mathrm{~m}, 2 \mathrm{H}), 4.28-4.21(\mathrm{~m}, 2 \mathrm{H}), 4.12(\mathrm{~h}, J=3.1,2.4 \mathrm{~Hz}, 4 \mathrm{H}), 4.01(\mathrm{~s}, 3 \mathrm{H}), 3.88-3.84(\mathrm{~m}, 2 \mathrm{H}), 3.73-3.66(\mathrm{~m}$, $3 \mathrm{H}), 3.63-3.58(\mathrm{~m}, 1 \mathrm{H}), 3.57-3.54(\mathrm{~m}, 2 \mathrm{H}), 3.49(\mathrm{~s}, 1 \mathrm{H}), 3.22(\mathrm{~d}, J=13.8 \mathrm{~Hz}, 2 \mathrm{H}), 3.09$ (d, $J=17.8 \mathrm{~Hz}, 1 \mathrm{H})$. HRMS (ESI): calcd for $\mathrm{C}_{31} \mathrm{H}_{36} \mathrm{O}_{10} \mathrm{~N}_{9} \mathrm{~S}_{2}[\mathrm{M}], m / z=758.20211$, found 758.20314 . The purity of the compound was analyzed by UHPLC. Gradient starts from 5\% B, 5\% - 95\% B for $3.5 \mathrm{~min}$; 95\% - 100\% for 0.05 min, wash. The product 2 was eluted at 2.49 min and was detected at $270 \mathrm{~nm}$.

\section{Cephalosporin derivative (4)}

RP-HPLC (Hydro): Gradient 0\% B for $14 \mathrm{~min}$; 0\% - 20\% B for $16 \mathrm{~min} ; 20 \%$ - 100\% B for $2 \mathrm{~min}$, wash. The desired product, eluting at $4.3 \mathrm{~min}$, was collected and lyophilized to afford product $4(3.56 \mathrm{mg}, 0.072 \mathrm{mmol}, 10 \%)$ as a white solid. ${ }^{1}$ H NMR (500 MHz, MeOD) $\delta 9.23(\mathrm{~d}, J=6.7 \mathrm{~Hz}, 2 \mathrm{H}), 8.14(\mathrm{~d}, J=6.7 \mathrm{~Hz}, 2 \mathrm{H}), 5.87(\mathrm{~d}, J=4.2 \mathrm{~Hz}, 1 \mathrm{H}), 5.73$ $(\mathrm{d}, J=14.0 \mathrm{~Hz}, 1 \mathrm{H}), 5.32(\mathrm{~d}, J=14.0 \mathrm{~Hz}, 1 \mathrm{H}), 5.18(\mathrm{~d}, J=4.2 \mathrm{~Hz}, 1 \mathrm{H}), 4.52(\mathrm{~s}, 2 \mathrm{H}), 4.02(\mathrm{~s}, 3 \mathrm{H}), 3.74-3.66(\mathrm{~m}$, $1 \mathrm{H}), 3.24-3.19$ (m, 1H). HRMS (ESI): calcd for $\mathrm{C}_{19} \mathrm{H}_{21} \mathrm{O}_{5} \mathrm{~N}_{8} \mathrm{~S}_{2}{ }^{+}[\mathrm{M}]^{+}, m / z=505.10708$, found 505.10666. The purity of the compound was analyzed by UHPLC. Gradient starts from 5\% B, 5\% - 95\% B for $3.5 \mathrm{~min} ; 95 \%-100 \%$ for $0.05 \mathrm{~min}$, wash. The product 4 was eluted at $0.34 \mathrm{~min}$ and was detected at $270 \mathrm{~nm}$.

\section{Cephalosporin derivative with photo linker (6)}

RP-HPLC: Gradient 5\% B for $14 \mathrm{~min}$; 5\% - 45\% B for $56 \mathrm{~min}$; 45\% - 100\% B for $4 \mathrm{~min}$, wash. The desired product, eluting at $34.4 \mathrm{~min}$, was collected and lyophilized to afford product $6(0.35 \mathrm{mg}, 0.052 \mathrm{mmol}, 1 \%)$ as a slightly yellowish solid. ${ }^{1}$ H NMR (500 MHz, MeOD) $\delta 8.82(\mathrm{~d}, J=6.7 \mathrm{~Hz}, 2 \mathrm{H}), 8.62(\mathrm{~d}, J=6.7 \mathrm{~Hz}, 1 \mathrm{H}), 8.31(\mathrm{~s}, 1 \mathrm{H}), 8.06$ $(\mathrm{d}, J=6.6 \mathrm{~Hz}, 2 \mathrm{H}), 8.01(\mathrm{~d}, J=9.0 \mathrm{~Hz}, 1 \mathrm{H}), 7.90-7.85$ (m, 1H), $7.03(\mathrm{~d}, J=2.7 \mathrm{~Hz}, 1 \mathrm{H}), 6.84-6.82(\mathrm{~m}, 1 \mathrm{H}), 6.81$ $(\mathrm{dd}, J=9.0,2.7 \mathrm{~Hz}, 1 \mathrm{H}), 5.65(\mathrm{~d}, J=3.9 \mathrm{~Hz}, 1 \mathrm{H}), 5.61(\mathrm{~d}, J=14.2 \mathrm{~Hz}, 1 \mathrm{H}), 5.41(\mathrm{~d}, J=3.9 \mathrm{~Hz}, 1 \mathrm{H}), 5.29(\mathrm{~d}, J=$ $14.2 \mathrm{~Hz}, 1 \mathrm{H}), 4.60$ (s, 2H), 4.12 (s, 2H), 4.10 (s, 2H), 4.05 (s, 3H). HRMS (ESI): calcd for $\mathrm{C}_{26} \mathrm{H}_{26} \mathrm{O}_{8} \mathrm{~N}_{9} \mathrm{~S}_{2}^{+}[\mathrm{M}]^{+}, \mathrm{m} / \mathrm{z}$ $=656.13403$, found 656.13410 . The purity of the compound was analyzed by UHPLC. Gradient starts from 5\% B, 
$5 \%-95 \%$ B for $3.5 \mathrm{~min} ; 95 \%-100 \%$ for $0.05 \mathrm{~min}$, wash. The product 6 was eluted at $0.91 \mathrm{~min}$ and was detected at $270 \mathrm{~nm}$.

Photolysis experiment. Photolysis experiments were performed using a Sina UV lamp (SI-MA-032-W; equipped with UV lamps $4 \times 9,365 \mathrm{~nm}$ ) at the distance of $\sim 5 \mathrm{~cm}$. See the Supporting Information for the detailed procedure.

Microbiological Assays. Bacterial Strains, Media, Reagents and Equipment. Bacillus subtilis (B. subtilis, ATCC 6633) Staphylococcus aureus (VSSA strain ATCC 29213), methicillin and oxacillin-resistant Staphylococcus aureus (MRSA strain ATCC 43300), Gram-negative Escherichia coli (strain ATCC 25922) and Pseudomonas aeruginosa (strain ATCC 27853) was purchased from either the German Collection of Microorganisms and Cell Cultures (DSMZ) or the American Type Culture Collection (ATCC). The bacteria culture was stored at $-80{ }^{\circ} \mathrm{C}$, and new cultures were prepared by streaking on Luria Broth (LB) or Trypsic Soy agar plates. The overnight culture was prepared by inoculating a single colony into a sterile plastic tube $(15 \mathrm{~mL})$ containing the bacteria medium $(5 \mathrm{~mL}, \mathrm{LB}$ or Trypsic Soy) and the cultures were shaken $(200 \mathrm{rcf} / \mathrm{min})$ overnight at $37^{\circ} \mathrm{C}$. Synthesized compounds were prepared in water at stock concentrations of $1 \mathrm{mg} / \mathrm{mL}$. The microplate reader used for the experiments was the Synergy $\mathrm{H} 1$ apparatus from BioTek. The Incubation assays were performed using an Eppendorf Thermomixer Compact with 1.5 $\mathrm{mL}$ blocks at $25{ }^{\circ} \mathrm{C}$ with a mixing speed of $700 \mathrm{rpm}$. Optical density for bacterial suspension adjustment was measured by Biochrom Cell Density Meter Ultrospec 10.

MICs of Tested Compounds. The minimum inhibitory concentration (MIC) of tested compounds and control antibiotics was determined using the broth microdilution method according to the guidelines outlined by the European Committee on Antimicrobial Susceptibility Testing (EUCAST). ${ }^{52}$ See the Supporting Information for the detailed procedure.

Time-resolved bacterial growth analysis. In 96-well microtiter plate, two-fold serial dilutions of antibiotics 1 or 2 (ranging from $64 \mu \mathrm{g} / \mathrm{ml}$ to $0.125 \mu \mathrm{g} / \mathrm{ml}$ ) were prepared in Cation-adjusted Mueller-Hinton-II broth (MHB) in a final volume of $50 \mu \mathrm{l}$ for each second line of the plate. The mixture was UV-irradiated at a wavelength of $365 \mathrm{~nm}$ for $5 \mathrm{~min}$. Two-fold serial dilutions (ranging from $64 \mu \mathrm{g} / \mathrm{ml}$ to $0.125 \mu \mathrm{g} / \mathrm{ml}$ ) were repeated for the unfilled lines in the same 96-well microtiter plate. Each well containing the antibiotic solution and the growth control wells were inoculated with $50 \mu \mathrm{l}$ of the bacterial suspension in concentration $1 \times 10^{6} \mathrm{cfu} / \mathrm{ml}^{-1}$, which results in final desired inoculum of $5 \times 10^{5} \mathrm{cfu} / \mathrm{ml}^{-1}$ in a volume $100 \mu 1$. The plate was then incubated at $37^{\circ} \mathrm{C}$ for $18 \mathrm{~h}$ and the cell density $(600 \mathrm{~nm})$ was measured every $20 \mathrm{~min}$ (with shaking between measurements) in a microplate reader. All experiments were performed in triplicates.

Antibacterial activity at exponential phase of bacterial growth. In 96-well microtiter plate, two-fold serial dilutions of antibiotics 1 or 2 (ranging from $64 \mu \mathrm{g} / \mathrm{ml}$ to $0.25 \mu \mathrm{g} / \mathrm{ml}$ ) were prepared in Mueller-Hinton-II broth (MHB) in a final volume of $50 \mu \mathrm{l}$ for each line of the plate. Each well containing the antibiotic solution and the growth control wells were inoculated with $50 \mu \mathrm{l}$ of the bacterial suspension in concentration $1 \times 10^{6} \mathrm{cfu} / \mathrm{ml}^{-1}$, which results in final desired inoculum of $5 \times 10^{5} \mathrm{cfu} / \mathrm{ml}^{-1}$ in a volume $100 \mu$. The plate was then incubated at $37^{\circ} \mathrm{C}$ for $18 \mathrm{~h}$ and the cell density $(600 \mathrm{~nm})$ was measured every $20 \mathrm{~min}$ (with shaking between measurements) in a microplate reader with the irradiation step after $7 \mathrm{~h}$ of bacterial growth. All experiments were performed in triplicates. 
Antibacterial activity of the by-products after the UV-irradiation. In 96-well microtiter plate, linkers 9a and 13a (concentration $64 \mathrm{ug} / \mathrm{mL}$ ) were prepared in Mueller-Hinton-II broth (MHB) in a final volume of $50 \mu \mathrm{l}$. Each well containing the linker solution and the growth control wells were UV-irradiated at a wavelength of $365 \mathrm{~nm}$ for $5 \mathrm{~min}$. After that the wells were inoculated with $50 \mu 1$ of the bacterial suspension in concentration $1 \times 10^{6} \mathrm{cfu} / \mathrm{ml}^{-1}$, which results in final desired inoculum of $5 \times 10^{5} \mathrm{cfu} / \mathrm{ml}^{-1}$ in a volume $100 \mu 1$. The plate was then incubated at $37^{\circ} \mathrm{C}$ for 18 $\mathrm{h}$ and the cell density $(600 \mathrm{~nm}$ ) was measured every $20 \mathrm{~min}$ (with shaking between measurements) in a microplate. All experiments were performed in triplicates.

\section{ASSOCIATED CONTENT}

\section{Supporting information}

${ }^{1} \mathrm{H}$ and ${ }^{13} \mathrm{C}$ NMR spectra of new compounds and details about photochemical data, microbiological assays, and bacterial growth curves.

\section{AUTHOR INFORMATION}

Corresponding Author

karl.gademann@uzh.ch

\section{Author Contributions}

I.S.S. and K. G. designed the study. I.S.S. carried out the synthesis and characterization of all derivatives and biological experiments. A. .T. carried out the synthesis optimization of cephalosporin derivatives. I. S. S. and K. G. analyzed data and discussed the results. I. S. S. and K. G. wrote the manuscript.

\section{ACKNOWLEDGMENTS}

We acknowledge the Swiss National Science Foundation (SNSF, Grant No. 182043) and a Bundesstipendium (to I.S.S.) for financial support.

\section{REFERENCES}

(1) Vallance, P.; Smart, T. G. (2006) The Future of Pharmacology. British Journal of Pharmacology, 147(S1), S304-S307. DOI: 10.1038/sj.bjp.0706454.

(2) Klatte, S.; Schaefer, H.-C.; Hempel, M. (2017) Pharmaceuticals in the Environment - A Short Review on Options to Minimize the Exposure of Humans, Animals and Ecosystems. Sustainable Chem. and Pharm. 5, 61-66. DOI: 10.1016/j.scp.2016.07.001.

(3) Edwards, I. R.; Aronson, J. K. (2000) Adverse Drug Reactions: Definitions, Diagnosis, and Management. The Lancet, 356(9237), 1255-1259. DOI: 10.1016/S0140-6736(00)02799-9.

(4) Davies, J.; Davies, D. (2010) Origins and Evolution of Antibiotic Resistance. Microbiology and Molecular Biology Reviews, 74 (3), 417-433. DOI: 10.1128/MMBR.00016-10. 
(5) Arias, C. A.; Murray, B. E. (2009) Antibiotic-Resistant Bugs in the 21st Century - A Clinical Super-Challenge. N. Engl. J. Med. 360 (5), 439-443. DOI: 10.1056/NEJMp0804651.

(6) Mattar, C.; Edwards, S.; Baraldi, E.; Hood, J. (2020) An Overview of the Global Antimicrobial Resistance Research and Development Hub and the Current Landscape. Curr. Opin. Microbiol. 57, 56-61. DOI: 10.1016/j.mib.2020.06.009.

(7) Alvarez-Lorenzo, C.; Concheiro, A. (2014) Smart Drug Delivery Systems: From Fundamentals to the Clinic. Chem. Commun. 50, 7743-7765. DOI: 10.1039/C4CC01429D.

(8) Wang, S.; Huang, P.; Chen, X. (2016) Stimuli-Responsive Programmed Specific Targeting in Nanomedicine. ACS Nano, 10 (3), 2991-2994. DOI: 10.1021/acsnano.6b00870.

(9) Velema, W. A.; Szymanski, W.; Feringa, B. L. (2014) Photopharmacology: Beyond Proof of Principle. J. Am. Chem. Soc. 136 (6), 2178-2191. DOI: 10.1021/ja413063e.

(10) Ankenbruck, N.; Courtney, T.; Naro, Y.; Deiters, A. (2018) Optochemical Control of Biological Processes in Cells and Animals. Angew. Chem. Int. Ed. 57, 2768-2798. DOI:

10.1002/ange.201700171.

(11) Welleman, I. M.; Hoorens, M. W. H.; Feringa, B. L.; Boersma, H. H.; Szymański, W. (2020) Photoresponsive Molecular Tools for Emerging Applications of Light in Medicine. Chem. Sci. 11, 11672-11691. DOI: 10.1039/d0sc04187d.

(12) Wegener, M.; Hansen, M. J.; Driessen, A. J. M.; Szymanski, W.; Feringa, B. L. (2017) Photocontrol of Antibacterial Activity: Shifting from UV to Red Light Activation. J. Am. Chem. Soc. 139, 17979-17986. DOI: 10.1021/jacs.7b09281.

(13) Weston, C. E.; Krämer, A.; Colin, F.; Yildiz, Ö.; Baud, M. G. J.; Meyer-Almes, F.-J.; Fuchter, M. J. (2017) Toward Photopharmacological Antimicrobial Chemotherapy Using Photoswitchable Amidohydrolase Inhibitors. ACS Infect. Dis. 3, 152-161. DOI: 10.1021/acsinfecdis.6b00148.

(14) Velema, W. A.; Hansen, M. J.; Lerch, M. M.; Driessen, A. J. M.; Szymanski, W.; Feringa, B. L. (2015) Ciprofloxacin-Photoswitch Conjugates: A Facile Strategy for Photopharmacology. Bioconjugate Chem. 26, 2592-2597. DOI: 10.1021/acs.bioconjchem.5b00591.

(15) Velema, W. A.; van der Berg, J. P.; Hansen, M. J.; Szymanski, W.; Driessen, A. J. M.; Feringa, B. L. (2013) Optical Control of Antibacterial Activity. Nature Chemistry, 5 (11), 924-928. DOI: 10.1038/nchem.1750.

(16) Fu, X.; Bai, H.; Qi, R.; Zhao, H.; Peng, K.; Lv, F.; Liu, L.; Wang, S. (2019) Optically-Controlled Supramolecular Self-Assembly of an Antibiotic for Antibacterial Regulation. Chem. Comm. 55 (96), 14466-14469. DOI: $10.1039 / \mathrm{c} 9 \mathrm{cc} 07999 \mathrm{~h}$. 
(17) van der Berg, J. P.; Velema, W. A.; Szymanski, W.; Driessen, A. J. M.; Feringa, B. L. (2015) Controlling the Activity of Quorum Sensing Autoinducers with Light. Chem. Sci., 6, 3593-3598. DOI: $10.1039 / \mathrm{c} 5 \mathrm{sc} 00215 \mathrm{j}$.

(18) Hansen, M. J.; Hille, J. I. C.; Szymanski, W.; Driessen, A. J. M.; Feringa, B. L. (2019) Easily Accessible, Highly Potent, Photocontrolled Modulators of Bacterial Communication. Chem, 5, 1293-1301. DOI: 10.1016/j.chempr.2019.03.005.

(19) Babii, O.; Afonin, S.; Berditsch, M.; Reißer, S.; Mykhailiuk, P. K.; Kubyshkin, V. S.; Steinbrecher, T.; Ulrich, A. S.; Komarov, I. V. (2014) Controlling Biological Activity with Light: DiaryletheneContaining Cyclic Peptidomimetics. Angew. Chem. Int. Ed. 53, 3392-3395. DOI: 10.1002/anie.201310019.

(20) Li, Z.; Wang, Y.; Li, M.; Zhang, H.; Guo, H.; Ya, H.; Yin, J. (2018) Synthesis and Properties of Dithienylethene-Functionalized Switchable Antibacterial Agents. Org. Biomol. Chem. 16, 69886997. DOI: $10.1039 / \mathrm{C} 8 \mathrm{OB} 01824 \mathrm{C}$.

(21) Pianowski, Z. L. (2019) Recent Implementations of Molecular Photoswitches into Smart Materials and Biological Systems. Chem. Eur. J. 25, 5128-5144. DOI: 10.1002/chem.201805814.

(22) Yeoh, Y. Q.; Yu, J.; Polyak, S. W.; Horsley, J. R.; Abell, A. D. (2018) Photopharmacological Control of Cyclic Antimicrobial Peptides. ChemBioChem, 19, 2591-2597. DOI: 10.1002/cbic.201800618.

(23) Lee, W.; Li, Z. H.; Vakulenko, S.; Mobashery, S. A (2000) Light-Inactivated Antibiotic. J. Med. Chem. 43, 128-132. DOI: 10.1021/jm980648a.

(24) Mizukami, S.; Hosoda, M.; Satake, T.; Okada, S.; Hori, Y.; Furuta, T.; Kikuchi, K. (2010) Photocontrolled Compound Release System Using Caged Antimicrobial Peptide. J. Am. Chem. Soc. 132, 9524-9525. DOI: 10.1021/ja102167m.

(25) Feng, Y.; Zhang, Y. Y.; Li, K.; Tian, N.; Wang, W. B.; Zhou, Q. X.; Wang, X. S. (2018) Photocleavable Antimicrobial Peptide Mimics for Precluding Antibiotic Resistance. New J. Chem. 42, 3192-3195. DOI: 10.1039/c8nj00015h.

(26) Ellis-Davies, G. C. R. (2007) Caged Compounds: Photorelease Technology for Control of Cellular Chemistry and Physiology. Nature Methods, 4, 619-628. DOI: 10.1038/nmeth1072.

(27) Binder, D.; Bier, C.; Grünberger, A.; Drobietz, D.; Hage-Hülsmann, J.; Wandrey, G.; Büchs, J.; Kohlheyer, D.; Loeschcke, A.; Wiechert, W.; Jaeger, K.-E.; Pietruszka, J.; Drepper, T. (2016) Photocaged Arabinose: A Novel Optogenetic Switch for Rapid and Gradual Control of Microbial Gene Expression. ChemBioChem, 17, 296-299. DOI: 10.1002/cbic.201500609. 
(28) Brieke, C.; Rohrbach, F.; Gottschalk, A.; Mayer, G.; Heckel, A. (2012) Light-Controlled Tools. Angew. Chem. Int. Ed. 51, 8446-8476. DOI: 10.1002/anie.201202134.

(29) Silva, J. M.; Silva, E.; Reis, R. L. (2019) Light-Triggered Release of Photocaged Therapeutics Where Are We Now? J. Controlled. Release, 298, 154-176. DOI: 10.1016/j.jconrel.2019.02.006.

(30) Guo, Z.; Ma, Y.; Liu, Y.; Yan, C.; Shi, P.; Tian, H.; Zhu, W.-H. (2018) Photocaged Prodrug under NIR Light-Triggering with Dual-Channel Fluorescence: In Vivo Real-Time Tracking for Precise Drug Delivery. Sci. China Chem. 61(10), 1293-1300. DOI: 10.1007/s11426-018-9240-6.

(31) Paul, A.; Mengji, R.; Bera, M.; Ojha, M.; Jana, A.; Singh, N. D. P. (2020) Mitochondria-Localized in Situ Generation of Rhodamine Photocage with Fluorescence Turn-on Enabling Cancer CellSpecific Drug Delivery Triggered by Green Light. Chem. Commun. 56, 8412-8415. DOI: 10.1039/D0CC03524F.

(32) Dcona, M. M.; Mitra, D.; Goehe, R. W.; Gewirtz, D. A.; Lebman, D. A.; Hartman, M. C. T. (2012) Photocaged Permeability: A New Strategy for Controlled Drug Release. Chem. Commun. 48, $4755-$ 4757. DOI: $10.1039 / \mathrm{c} 2 \mathrm{cc} 30819 \mathrm{c}$.

(33) Moodie, L. W. K.; Hubert, M.; Zhou, X.; Albers, M. F.; Lundmark, R.; Wanrooij, S.; Hedberg, C. (2019) Photoactivated Colibactin Probes Induce Cellular DNA Damage. Angew. Chem. Int. Ed. 58, 1417-1421. DOI: 10.1002/ange.201812326.

(34) Kumar, P.; Shukhman, D.; Laughlin, S. T. A Photocaged, (2016) Cyclopropene-Containing Analog of the Amino Acid Neurotransmitter Glutamate. Tetrahedron Lett. 57 (51), 5750-5752. DOI: 10.1016/j.tetlet.2016.10.106.

(35) Asad, N.; McLain, D. E.; Condon, A. F.; Gore, S.; Hampton, S. E.; Vijay, S.; Williams, J. T.; Dore, T. M. (2020) Photoactivatable Dopamine and Sulpiride to Explore the Function of Dopaminergic Neurons and Circuits. ACS Chem. Neurosci. 11(6), 939-951. DOI: 10.1021/acschemneuro.9b00675.

(36) Breitinger, H.-G. A.; Wieboldt, R.; Ramesh, D.; Carpenter, B. K.; Hess, G. P. (2000) Synthesis and Characterization of Photolabile Derivatives of Serotonin for Chemical Kinetic Investigations of the Serotonin 5-HT ${ }_{3}$ Receptor. Biochemistry, 39(18), 5500-5508. DOI: 10.1021/bi992781q.

(37) So, W. H.; Wong, C. T. T.; Xia, J. (2018) Peptide Photocaging: A Brief Account of the Chemistry and Biological Applications. Chin. Chem. Lett. 29(7), 1058-1062. DOI: 10.1016/j.cclet.2018.05.015.

(38) Weston, C. E.; Krämer, A.; Colin, F.; Yildiz, Ö.; Baud, M. G. J.; Meyer-Almes, F. J.; Fuchter, M. J. (2007) Toward Photopharmacological Antimicrobial Chemotherapy Using Photoswitchable Amidohydrolase Inhibitors. ACS Inf. Dis. 3 (2), 152-161. DOI: 10.1021/acsinfecdis.6b00148. 
(39) Buhr, F.; Kohl-Landgraf, J.; tom Dieck, S.; Hanus, C.; Chatterjee, D.; Hegelein, A.; Schuman, E. M.; Wachtveitl, J.; Schwalbe, H. (2015) Design of Photocaged Puromycin for Nascent Polypeptide Release and Spatiotemporal Monitoring of Translation. Angew. Chem. Int. Ed. 54, 3717-3721. DOI: 10.1002/anie.201410940.

(40) Elamri, I.; Heumüller, M.; Herzig, L-M..; Stirnal, E.; Wachtveitl, J.; Schuman, E. M.; Schwalbe, H. (2018) A New Photocaged Puromycin for an Efficient Labeling of Newly Translated Proteins in Living Neurons. ChemBioChem, 19 (23), 2458-2464. DOI: 10.1002/cbic.201800408.

(41) Shi, Y.; Truong, V. X.; Kulkarni, K.; Qu, Y.; Simon, G. P.; Boyd, R. L.; Perlmutter, P.; Lithgow, T.; Forsythe, J. S. (2015) Light-Triggered Release of Ciprofloxacin from an in Situ Forming Click Hydrogel for Antibacterial Wound Dressings. J. Mater. Chem. B, 3, 8771-8774. DOI: $10.1039 / \mathrm{c} 5 \mathrm{tb} 01820 \mathrm{j}$.

(42) Kumari, P.; Kulkarni, A.; Sharma, A. K.; Chakrapani, H. (2018) Visible-Light Controlled Release of a Fluoroquinolone Antibiotic for Antimicrobial Photopharmacology. ACS Omega, 3, 2155-2160. DOI: 10.1021/acsomega.7b01906.

(43) Velema, W. A.; van der Berg, J. P.; Szymanski, W.; Driessen, A. J. M.; Feringa, B. L. (2014) Orthogonal Control of Antibacterial Activity with Light. ACS Chem. Biol. 9, 1969-1974. DOI: $10.1021 / \mathrm{cb} 500313 \mathrm{f}$.

(44) Shchelik, I. S.; Sieber, S.; Gademann, K. (2020) Green Algae as a Drug Delivery System for the Controlled Release of Antibiotics. Chem. Eur. J. 26, 16644-16648. DOI: 10.1002/chem.202003821.

(45) Gualerzi, C. O., Brandi, L., Fabbretti, A., Pon, C. L., (2013) Antibiotics: Targets, Mechanisms and Resistance. Wiley-VCH Verlag GmbH \& Co. Weinheim, Germany. DOI: 10.1002/9783527659685.

(46) World Health Organization Model List of Essential Medicines: 21st List 2019.; Geneva. https://www.who.int/publications/i/item/WHOMVPEMPIAU2019.06 (retrieved January 11th, 2021)

(47) Boyce, J. M.; Cookson, B.; Christiansen, K.; Hori, S.; Vuopio-Varkila, J.; Kocagöz, S.; Öztop, A. Y.; Vandenbroucke-Grauls, C. M.; Harbarth, S.; Pittet, D. (2005) Meticillin-Resistant Staphylococcus aureus. The Lancet Infectious Diseases, 5, 653-663. DOI: 10.1016/S14733099(05)70243-7.

(48) Lambert, M.-L.; Suetens, C.; Savey, A.; Palomar, M.; Hiesmayr, M.; Morales, I.; Agodi, A.; Frank, U.; Mertens, K.; Schumacher, M.; Wolkewitz, M. (2011) Clinical Outcomes of Health-CareAssociated Infections and Antimicrobial Resistance in Patients Admitted to European Intensive-Care Units: A Cohort Study. Lancet Infect. Dis. 11, 30-38. DOI: 10.1016/S1473. 
(49) Suárez, C.; Peña, C.; Tubau, F.; Gavaldà, L.; Manzur, A.; Dominguez, M. A.; Pujol, M.; Gudiol, F.; Ariza, J. (2009) Clinical Impact of Imipenem-Resistant Pseudomonas aeruginosa Bloodstream Infections. Journal of Infection, 58, 285-290. DOI: 10.1016/j.jinf.2009.02.010.

(50) Miller, W. R.; Munita, J. M.; Arias, C. A. (2014) Mechanisms of Antibiotic Resistance in Enterococci. Expert Rev. Anti-Infect. Ther. 12(10), 1221-1236. DOI: 10.1586/14787210.2014.956092.

(51) Dahms, R. A. (1998) Third-Generation Cephalosporins and Vancomycin as Risk Factors for Postoperative Vancomycin-Resistant Enterococcus Infection. Archives of Surgery, 133, 1343-1346. DOI: 10.1001/archsurg.133.12.1343.

(52) Yoshizawa, H.; Kubota, T.; Itani, H.; Minami, K.; Miwa, H.; Nishitani, Y. (2004) New BroadSpectrum Parenteral Cephalosporins Exhibiting Potent Activity against Both Methicillin-Resistant Staphylococcus Aureus (MRSA) and Pseudomonas Aeruginosa. Part 3: 7ß-[2-(5-Amino-1,2,4Thiadiazol-3-Yl)-2- Ethoxyiminoacetamido] Cephalosporins Bearing 4-[3-(Aminoalkyl)-Ureido]-1Pyridinium at C-3'. Bioorg. Med. Chem. 12 (15), 4221-4231. DOI: 10.1016/j.bmc.2004.05.021.

(53) Daniel D. Long, James B. Aggen, Jason Chinn, Seok-Ki Choi, Burton G. Christensen,Paul R. Fatheree, David Green, Sharath S. Hegde, J. Kevin Judice, Koné Kaniga, KevinM. Krause, Michael Leadbetter, Martin S. Linsell, Daniel G. Marquess, Edmund J.Moran, Matthew B. Nodwell, John L. Pace, Sean G. Trapp, S. Derek Turner (2008) Exploring the Positional Attachment of Glycopeptide/bb-lactam Heterodimers. J. Antibiot. 61(10), 603-614. DOI: 10.1038/ja.2008.80.

(54) Teraji,T. Sakane, K. Goto, J. Cephem Compounds. U.S. Patent 4,463,000, Jun. 31, 1984.

(55) Wach, J.-Y.; Bonazzi, S.; Gademann, K. (2008) Antimicrobial Surfaces through Natural Product Hybrids. Angew. Chem. Int. Ed. 47 (37), 7123-7126. DOI: 10.1002/anie.200801570.

(56) EUCAST (2021). Broth Microdilution - EUCAST reading guide v 3.0.

(57) Pucci, M. J.; Boice-Sowek, J.; Kessler, R. E.; Dougherty, T. J. (1991) Comparison of Cefepime, Cefpirome, and Cefaclidine Binding Affinities for Penicillin-Binding Proteins in Escherichia coli K12 and Pseudomonas aeruginosa SC8329. Antimicrob. Agents Chemother., 35(11), 2312-2317 DOI: 10.1128/aac.35.11.2312

(58) Garau, J.; Wilson, W.; Wood, M.; Carlet, J. (1997) Fourth-Generation Cephalosporins: A Review of in Vitro Activity, Pharmacokinetics, Pharmacodynamics and Clinical Utility. Clinical Microbiology and Infection, 3(1), S87-S101. DOI: 10.1111/j.1469-0691.1997.tb00649.x.

(59) Theophel, K.; Schacht, V. J.; Schlüter, M.; Schnell, S.; Stingu, C.-S.; Schaumann, R.; Bunge, M. (2014) The Importance of Growth Kinetic Analysis in Determining Bacterial Susceptibility against 
Antibiotics and Silver Nanoparticles. Frontiers in Microbiology, 5(544), 1-10. DOI: 10.3389/fmicb.2014.00544.

(60) Tsushima, M.; Kano, Y.; Umemura, E.; Iwamatsu, K.; Tamura, A.; Shibahara, S. Novel (1998)

Cephalosporin Derivatives Possessing a Bicyclic Heterocycle at the 3-Position. Part II: Synthesis and Antibacterial Activity of 3-(5-Methylthiazolo[4,5- c ]Pyridinium-2-Y1)Thiomethylcephalosporin Derivatives and Related Compounds. Bioorg. Med. Chem. 6(9), 1641-1653. DOI: 10.1016/S09680896(98)00103-5.

(61) Saneyoshi, H.; Kondo, K.; Iketani, K.; Ono, A. (2017) Alkyne-Linked Reduction-Activated Protecting Groups for Diverse Functionalization on the Backbone of Oligonucleotides. Bioorg. Med. Chem. 25(13), 3350-3356. DOI: 10.1016/j.bmc.2017.04.020.

(62) Gottlieb, H. E., Kotlyar, V., and Nudelman, A. (1997) NMR chemical shifts of common laboratory solvents as trace impurities. J. Org. Chem. 62, 7512-7515. 


\section{Supporting information}

\section{Photolysis experiments}

Stock solutions (1 mM) of cephalosporin derivatives: Compounds $\mathbf{4}$ and $\mathbf{6}$ were dissolved in PBS buffer $(\mathrm{pH}=7.4)$ and diluted to obtain several concentrations $(2.5-20 \mu \mathrm{M})$. These solutions were used for the experiments shown below and for generating the calibration curve. All stock solutions were freshly prepared.

Calibration curves were built by plotting linear regression of the mass intensity versus the concentration of the standard. From these curves the coefficients of correlation $\left(\mathrm{R}^{2}\right)$ and slope were calculated.

- Analysis of the solution after the UV-irradiation of cephalosporin derivative 6

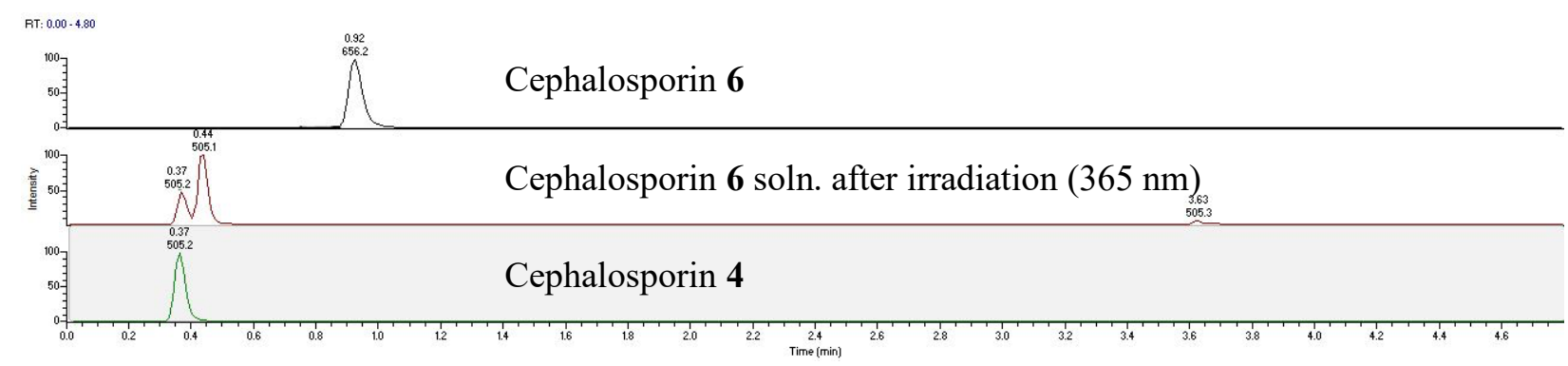

Figure S1. UHPLC-MS chromatograms comparison recorded in SIM-(+)mode of cephalosporin derivative 6. From top to bottom: synthetic cephalosporin derivative $\mathbf{6}$, product after irradiation of the cephalosporine derivative 6 solution, synthetic cephalosporin derivative 4 .

- Photolysis experiment of compound 6

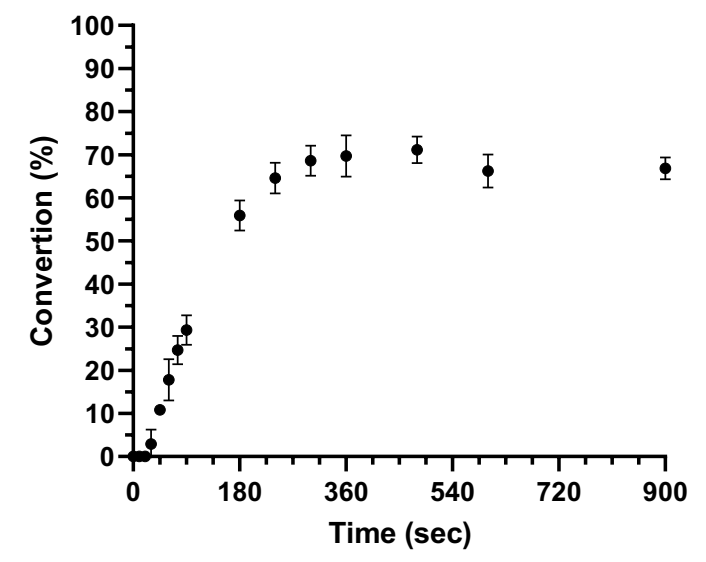

Figure S2. Analysis of the conversion of compound 6 into compound 4 after sample irradiation at a wavelength of $365 \mathrm{~nm}$ during different time. Data points represent mean value $\pm \operatorname{SD}(n=3)$. 
Calibration curve

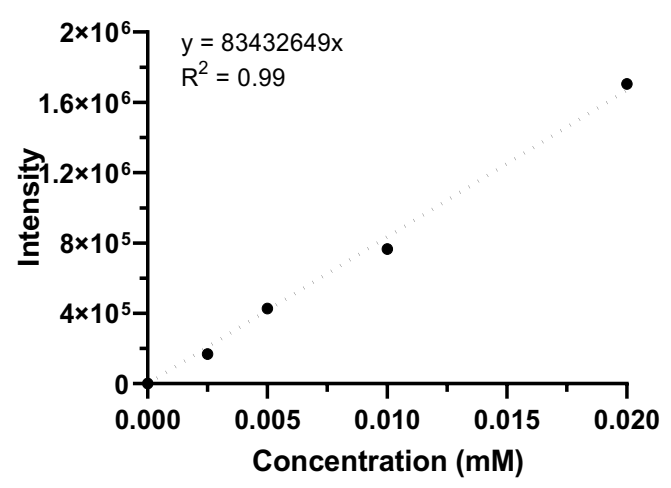

Calibration curve

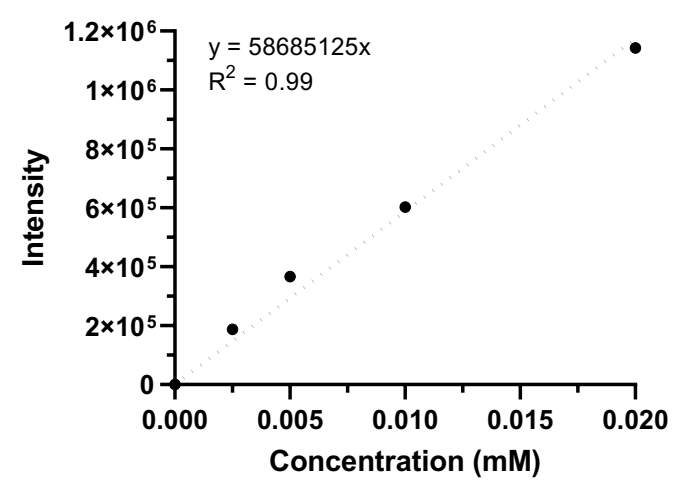

Figure S3. Calibration curves for compound 4 on the left and for compound 6 on the right.

- Analysis of the solution after UV-irradiation of compound $\mathbf{6}$ for by-products.

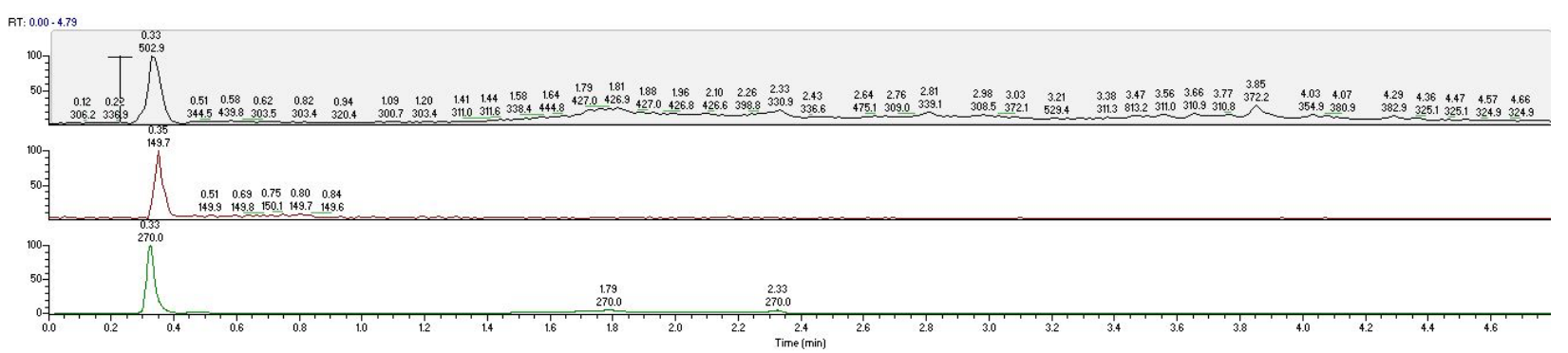

Figure S4. UHPLC-MS chromatograms recorded in SIM (-)mode after the UV irradiation of a solution of the cephalosporin derivative 6. From top to bottom: product 4, by-product (linker), UV-trace $(270 \mathrm{~nm})$ of the solution after the UV irradiation.

\section{Microbiological assays}

- $M I C$

In a 96-well microtiter plate, two-fold serial dilutions of the respective antibiotics (ranging from $64 \mu \mathrm{g} / \mathrm{ml}$ to $0.125 \mu \mathrm{g} / \mathrm{ml}$ ) were prepared in Cation-adjusted Mueller-Hinton-II broth (MHB) in a final volume of $50 \mu \mathrm{l}$. The bacterial suspensions turbidity was adjusted to a McFarland Standard 0.5 (absorbance at $600 \mathrm{~nm} 0.08-0.13$ ) to get approximately $1 \times 10^{8} \mathrm{cfu} \mathrm{m}^{-1}$, then the bacterial suspension was diluted by a factor of 1:100 for $S$. aureus, $P$. aeruginosa, by a factor 1:200 for $B$. subtilis and by a factor 1:150 for E. coli in MHB. Each well containing the antibiotic solution and the growth control well were inoculated with $50 \mu \mathrm{l}$ of the bacterial suspension. This results in the final desired inoculum of $5 \times 10^{5} \mathrm{cfu} \mathrm{m}^{-1}$ in a volume $100 \mu \mathrm{l}$. The plate was then incubated at 37 ${ }^{\circ} \mathrm{C}$ for $18 \mathrm{~h}$, after which minimal inhibitory concentration (MIC) was determined by visual inspection and it is defined as the minimal concentration of a compound that prevents microbial growth. 
Table S1. MIC values of synthesized compounds

\begin{tabular}{|l|c|c|c|c|c|c|}
\hline & \multicolumn{5}{|c|}{ MIC $(\boldsymbol{\mu g} / \mathbf{m L})$} \\
\hline Bacterial Strains & $\mathbf{1}$ & $\mathbf{3}$ & $\mathbf{5}$ & $\mathbf{2}$ & $\mathbf{4}$ & $\mathbf{6}$ \\
\hline Gram-negative & & & & & \\
\hline E. coli ATCC 25922 & - & - & - & 8 & $1-2$ & 1 \\
\hline P. aeruginosa ATCC 27853 & - & - & - & 64 & $2-4$ & 32 \\
\hline Gram-positive & & & & & & \\
\hline B. subtilis ATCC 6633 & 32 & $0.06-0.125$ & 0.125 & 8 & $2-4$ & 1 \\
\hline S. aureus ATCC 29213 & $>64$ & $0.5-1$ & 0.5 & 32 & 8 & 4 \\
\hline S. aureus ATCC 43300 & $>64$ & $1-2$ & 1 & 64 & 32 & 16 \\
\hline
\end{tabular}

- Time-resolved bacterial growth analysis

\section{Results for antibiotic 1}
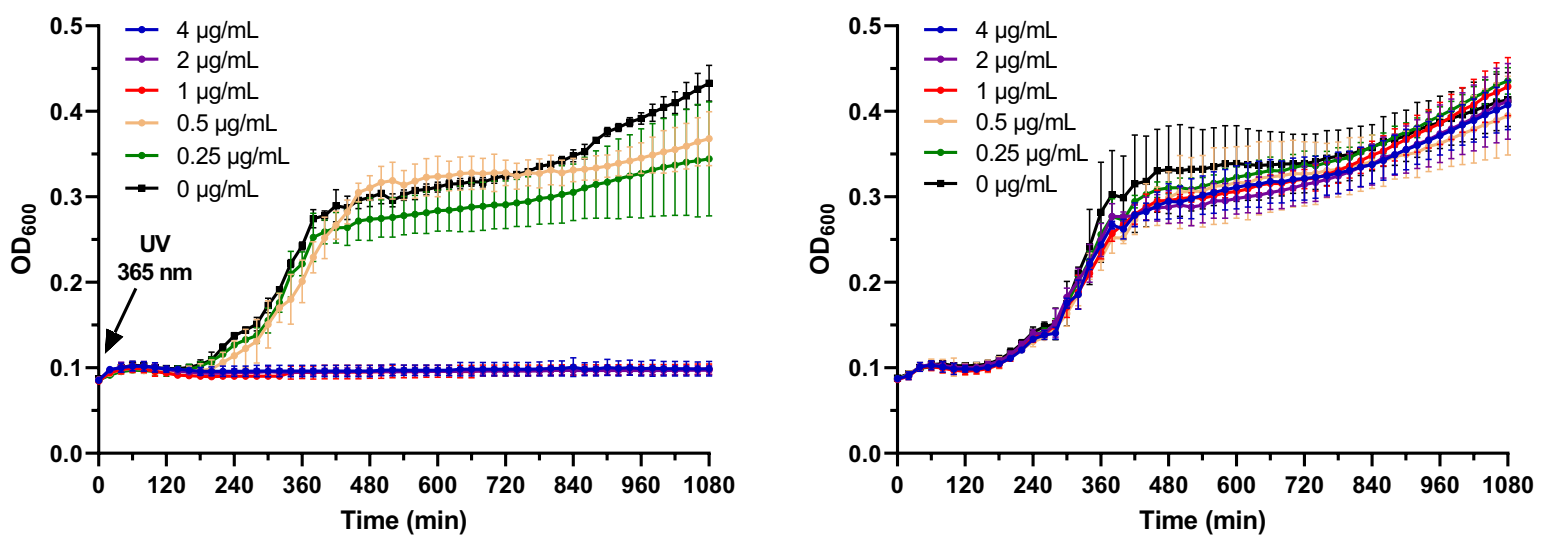

Figure S5. Bacterial growth curves of $B$. subtilis ATCC 6633 incubated with antibiotic 1 at increasing concentrations. Compound 7 after UV-irradiation at $365 \mathrm{~nm}$ for $5 \mathrm{~min}$ (left graph), without UV-irradiation (right graph). Data points represent mean value $\pm \mathrm{SD}(\mathrm{n}=3)$.
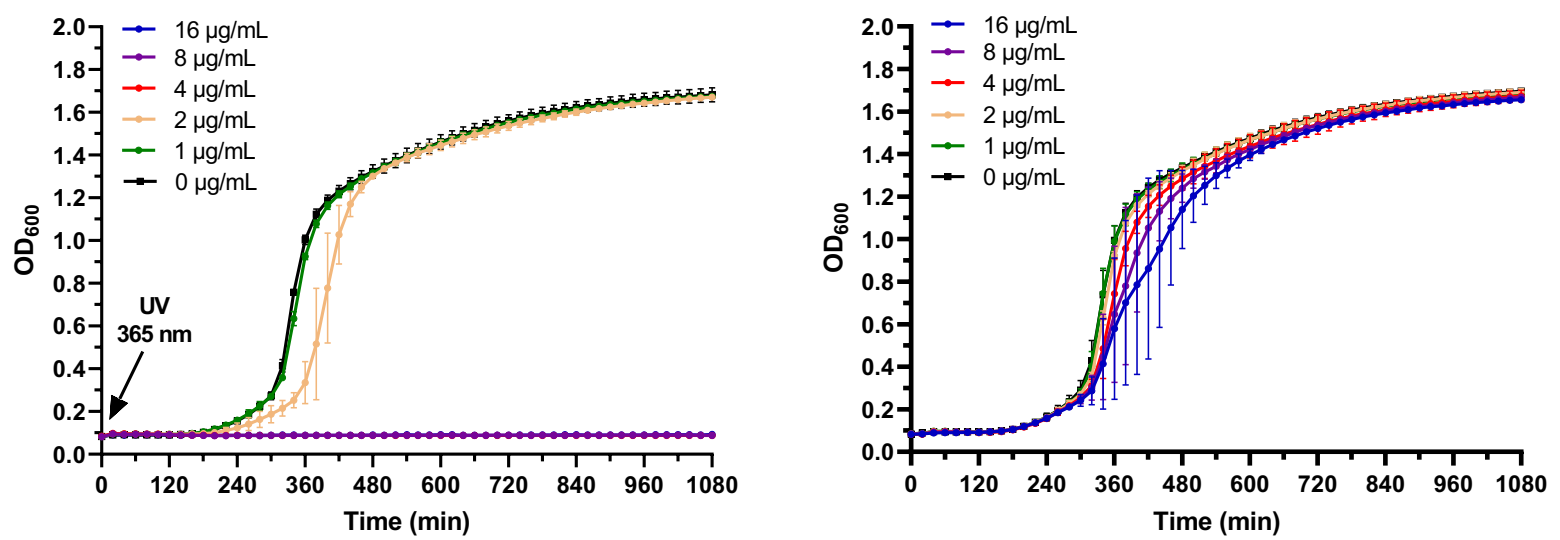
Figure S6. Bacterial growth curves of $S$. aureus ATCC 29213 incubated with antibiotic 1 at increasing concentrations. Compound 7 after UV-irradiation at $365 \mathrm{~nm}$ for $5 \mathrm{~min}$ (left graph), without UV-irradiation (right graph). Data points represent mean value $\pm \operatorname{SD}(n=3)$.
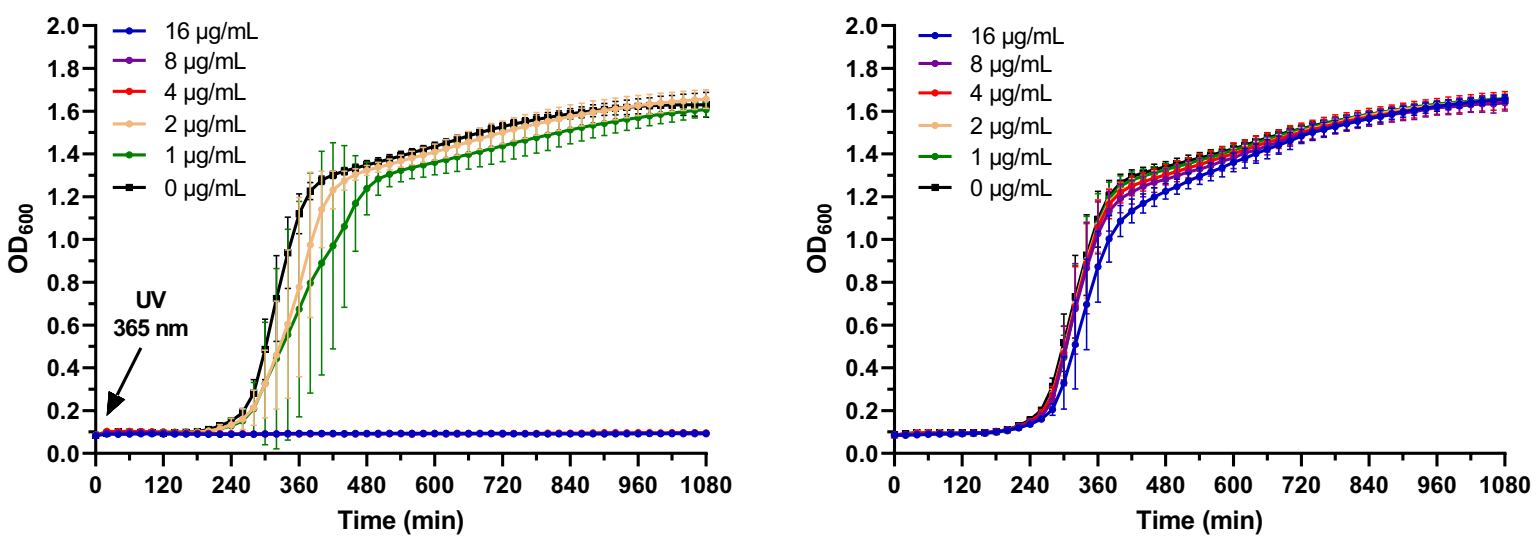

Figure S7. Bacterial growth curves of $S$. aureus ATCC 43300 incubated with antibiotic 1 at increasing concentrations. Compound 7 after UV-irradiation at $365 \mathrm{~nm}$ for $5 \mathrm{~min}$ (left graph), without UV-irradiation (right graph). Data points represent mean value $\pm \operatorname{SD}(n=3)$.

\section{Results for antibiotic 2}
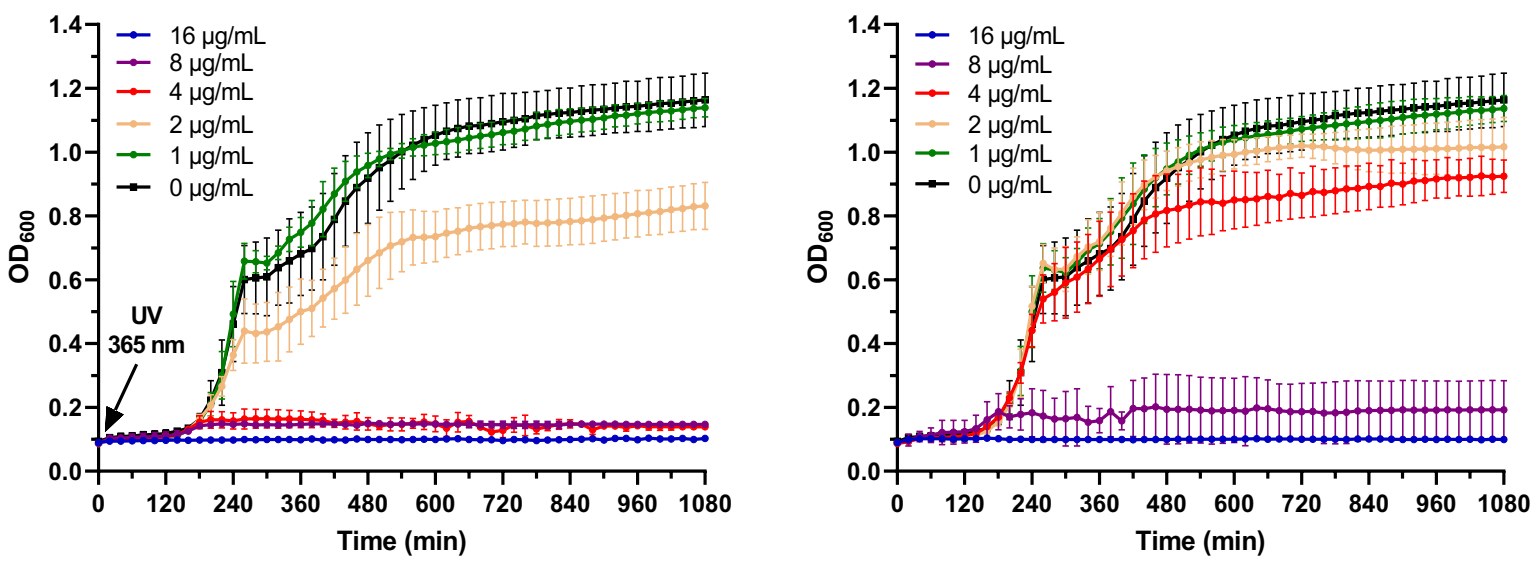

Figure S8. Bacterial growth curves of E. coli ATCC 25922 incubated with antibiotic 2 at increasing concentrations. Compound 2 after UV-irradiation at $365 \mathrm{~nm}$ for $5 \mathrm{~min}$ (left graph), without UV-irradiation (right graph). Data points represent mean value $\pm \mathrm{SD}(\mathrm{n}=3)$.

\section{- Antibacterial activity of the by-products after the UV-irradiation}<smiles>COCCOC(C)(C)COC(C)(C)CCNC(=O)CCCOc1cc([N+](=O)[O-])c(C(C)=O)cc1OC</smiles>

Scheme S1. Proposed decomposition products of the linker 9a after UV-irradiation<smiles>COCCOCCOc1ccc([N+](=O)[O-])c(C=O)c1</smiles>

Scheme S2. Proposed decomposition products of the linker 12a after UV-irradiation 


\section{Results for the linker 9a}

S. aureus ATCC 29213

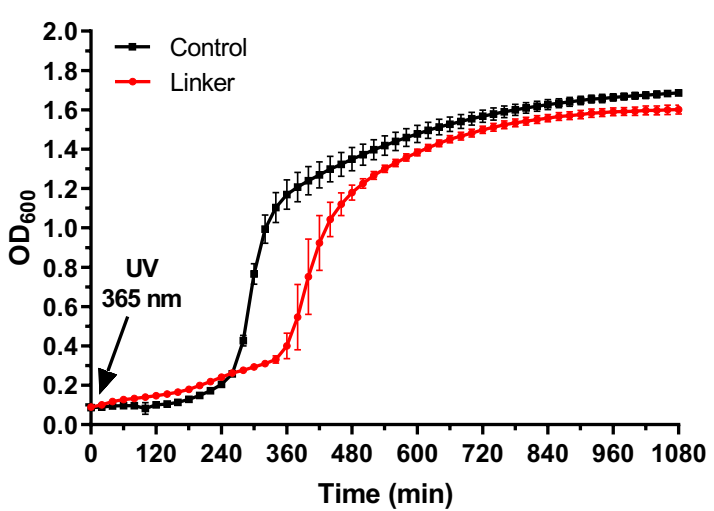

S.aureus ATCC 43300

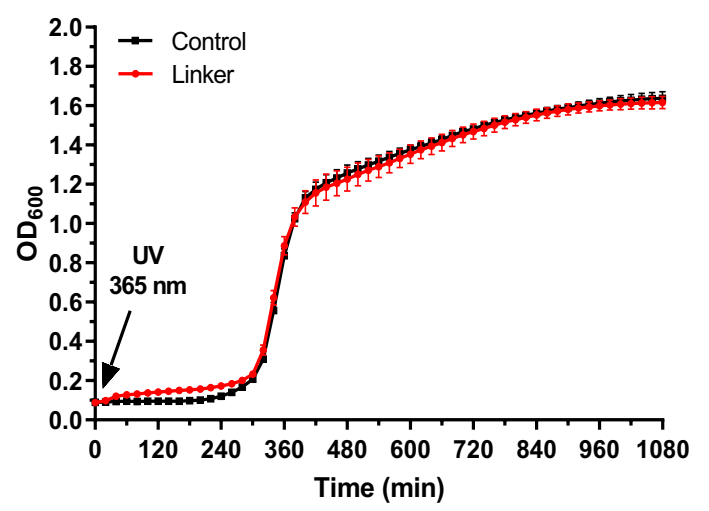

B. subtilis ATCC 6633

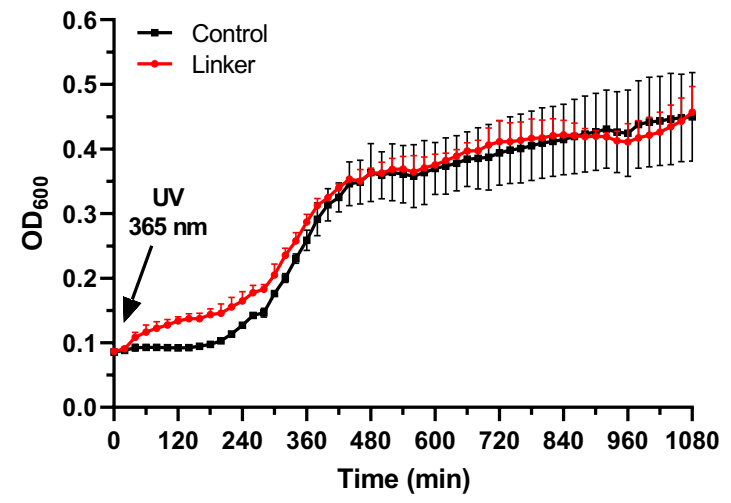

Figure S9. Growth of $S$. aureus ATCC 29213, S. aureus ATCC 43300, B. subtilis ATCC 6633 incubated with linker 9a and UV-irradiated at $365 \mathrm{~nm}$ for $5 \mathrm{~min}$ at time 0 . The results represent data for the linker concentrations $64 \mu \mathrm{g} / \mathrm{mL}$. Data points represent mean value $\pm \mathrm{SD}(\mathrm{n}=3)$.

\section{Results for the linker 12a}
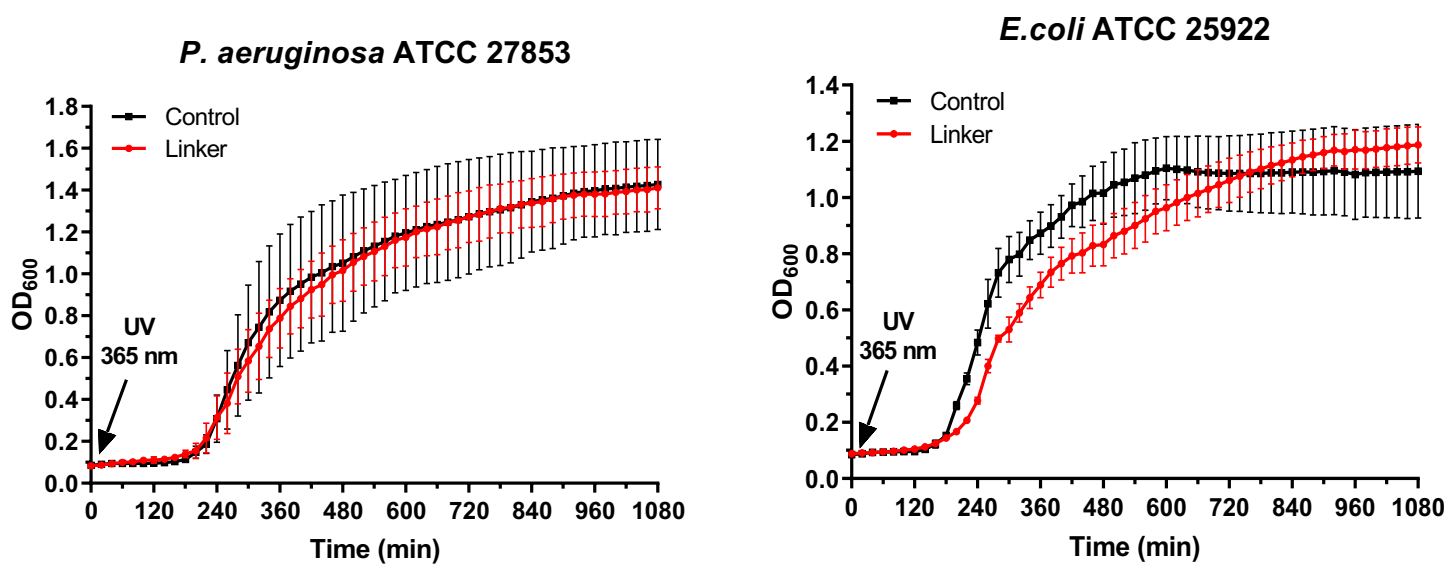

Figure S10. Growth of $P$. aeruginosa ATCC 27853, E. coli ATCC 25922 incubated with linker 12a and $\mathrm{UV}$-irradiated at $365 \mathrm{~nm}$ for $5 \mathrm{~min}$ at time 0 . The results represent data for the linker concentrations 64 $\mu \mathrm{g} / \mathrm{mL}$. Data points represent mean value $\pm \mathrm{SD}(\mathrm{n}=3)$. 
3. NMR spectra of newly synthesized compounds

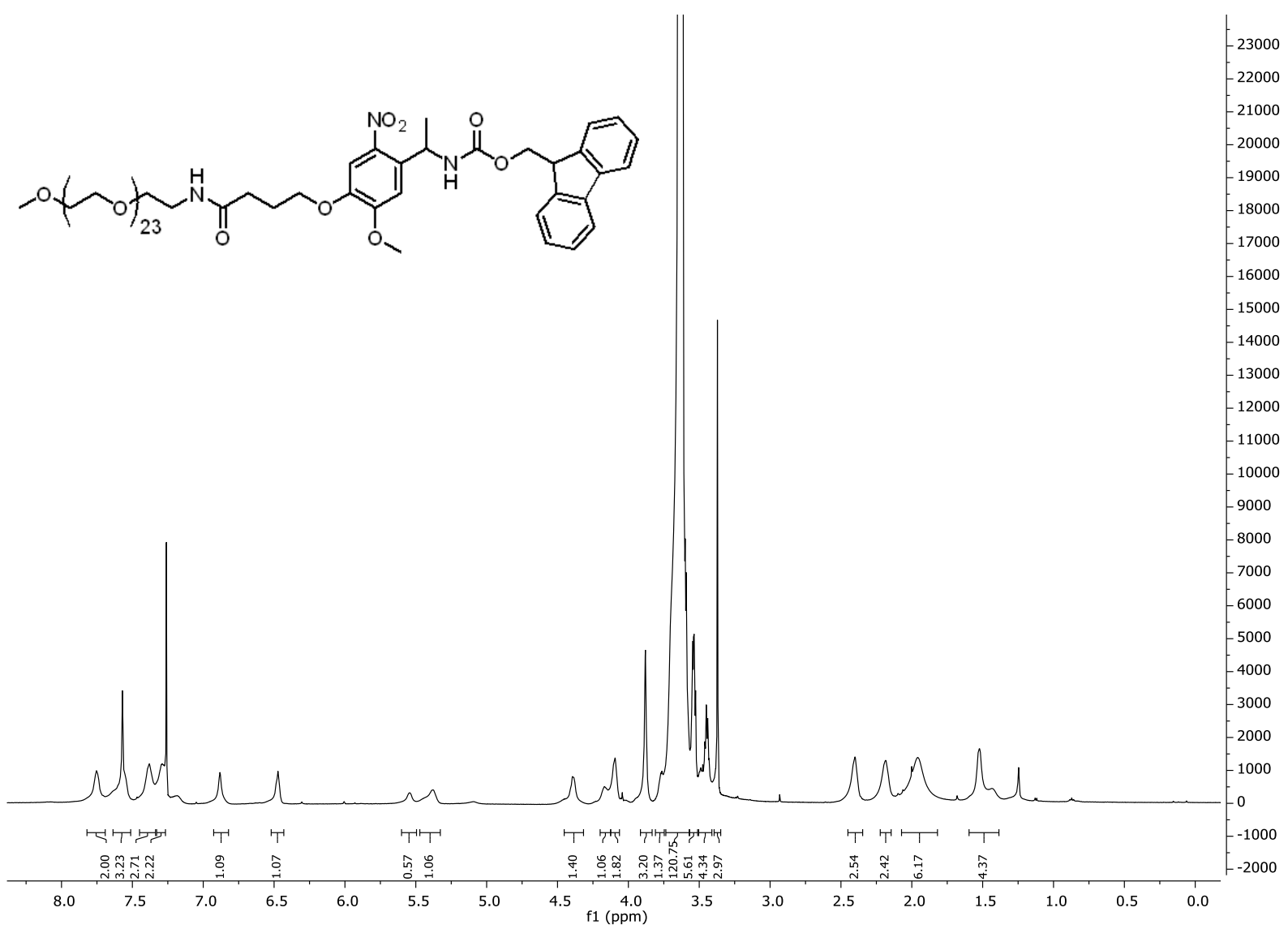

$500 \mathrm{MHz}{ }^{1} \mathrm{H}-\mathrm{NMR}$ in $\mathrm{CDCl}_{3}$ of $\mathbf{8 a}$

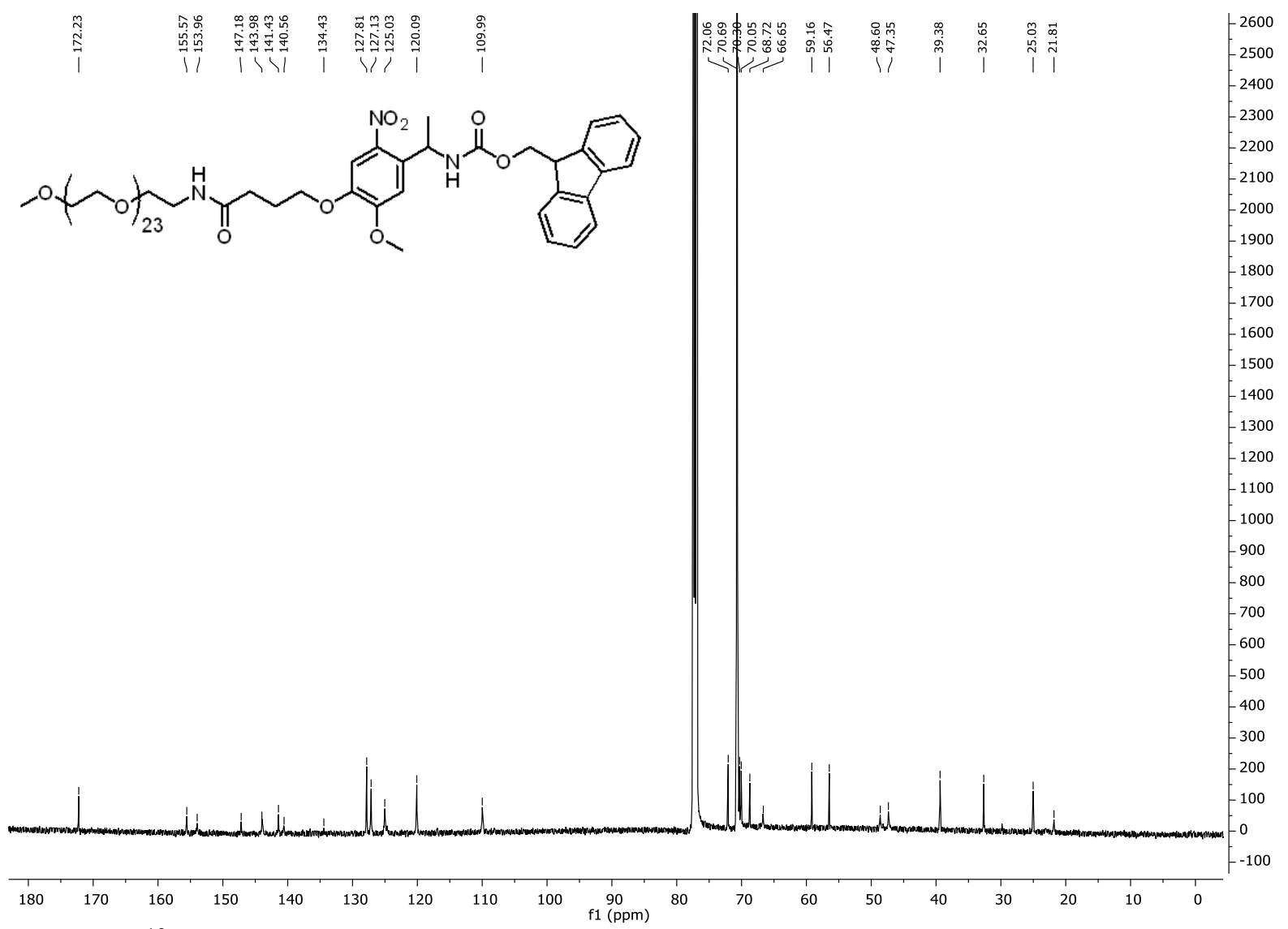

$126 \mathrm{MHz}{ }^{13} \mathrm{C}-\mathrm{NMR}$ in $\mathrm{CDCl}_{3}$ of $\mathbf{8 a}$ 


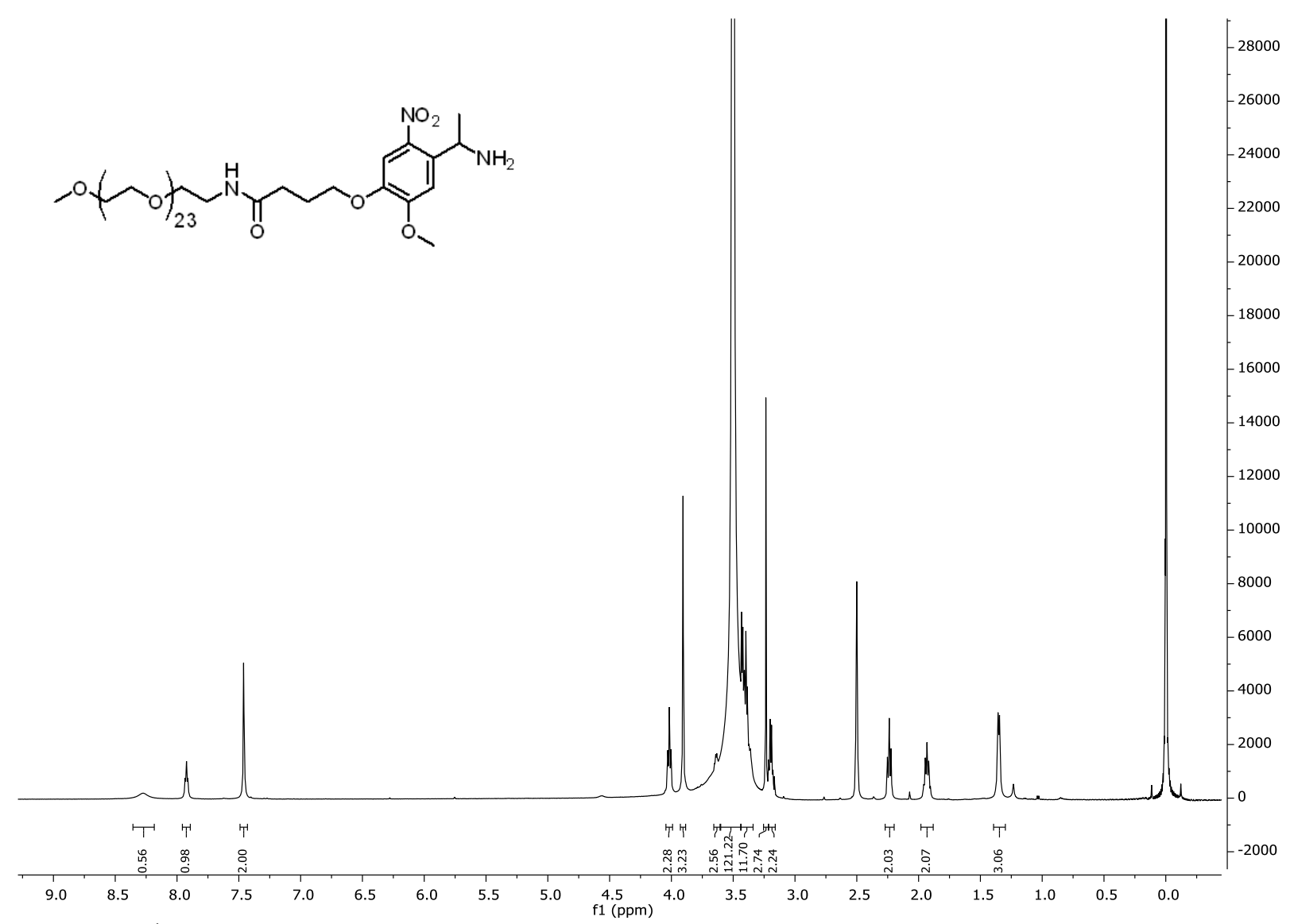

$500 \mathrm{MHz}{ }^{1} \mathrm{H}-\mathrm{NMR}$ in DMSO-d $\mathrm{d}_{6}+0.01 \% \mathrm{TMS}$ of 9a

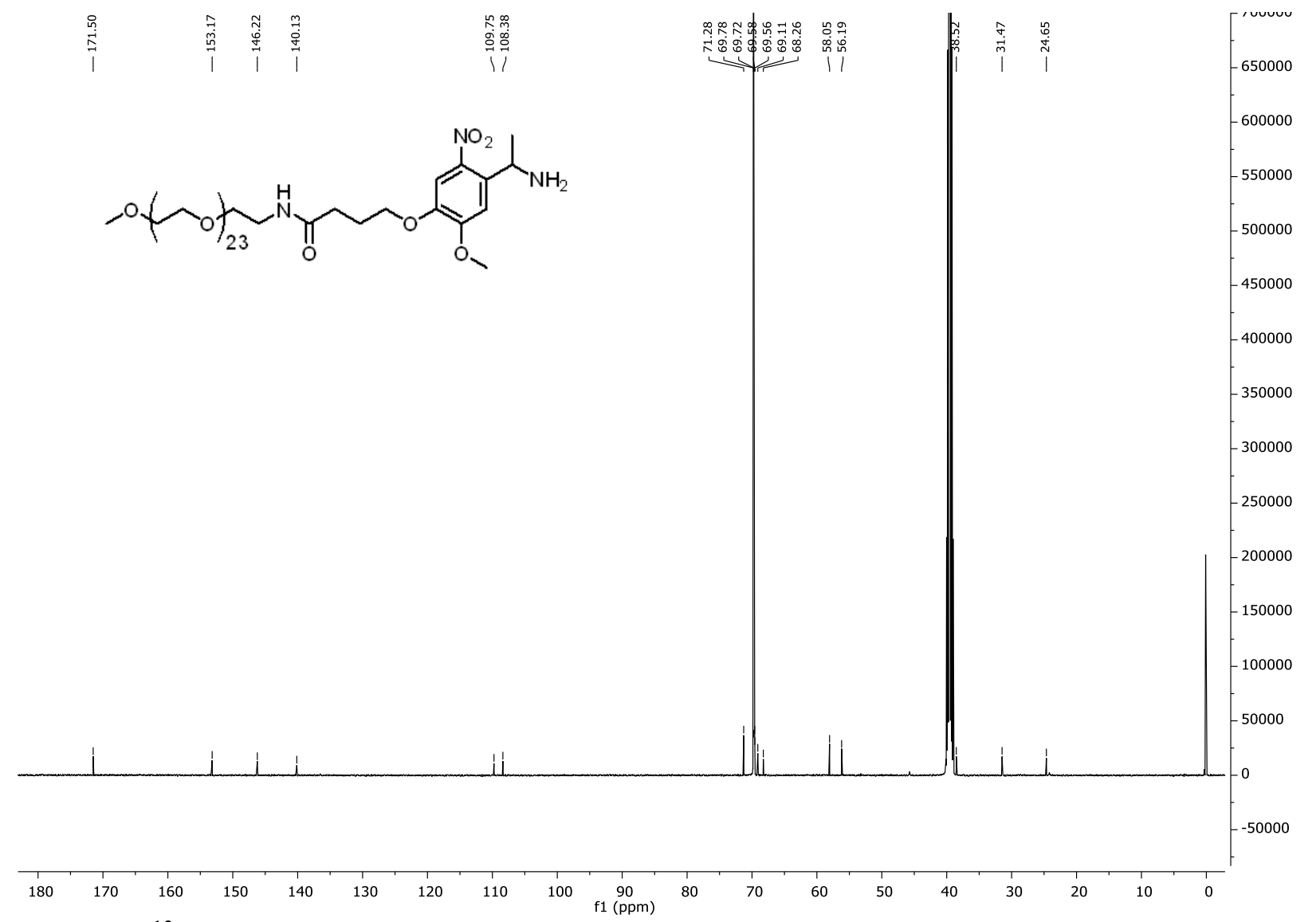

$126 \mathrm{MHz}{ }^{13} \mathrm{C}-\mathrm{NMR}$ in DMSO-d $6+0.01 \% \mathrm{TMS}$ of $9 \mathbf{a}$ 


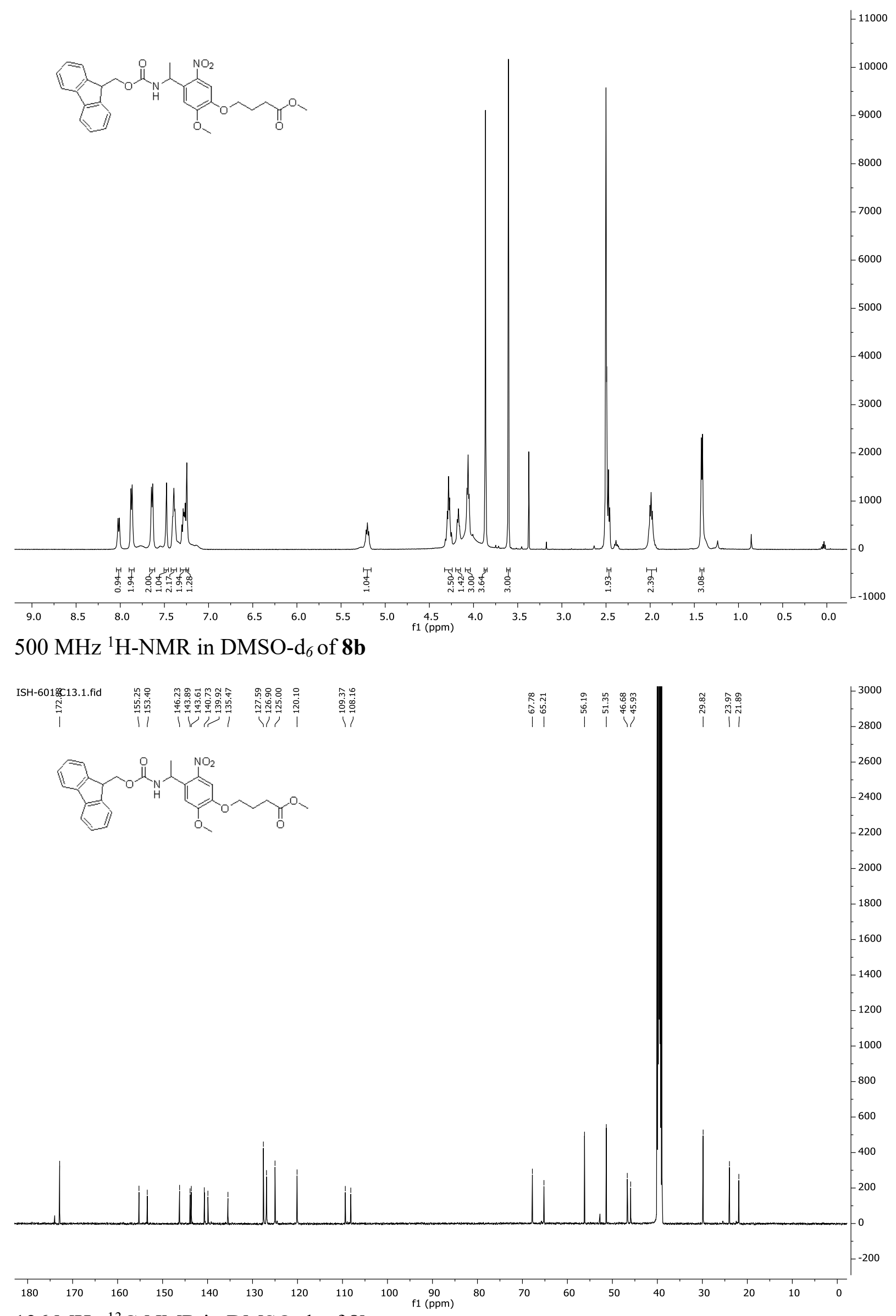

$126 \mathrm{MHz}{ }^{13} \mathrm{C}-\mathrm{NMR}$ in DMSO-d 6 of $\mathbf{8 b}$ 


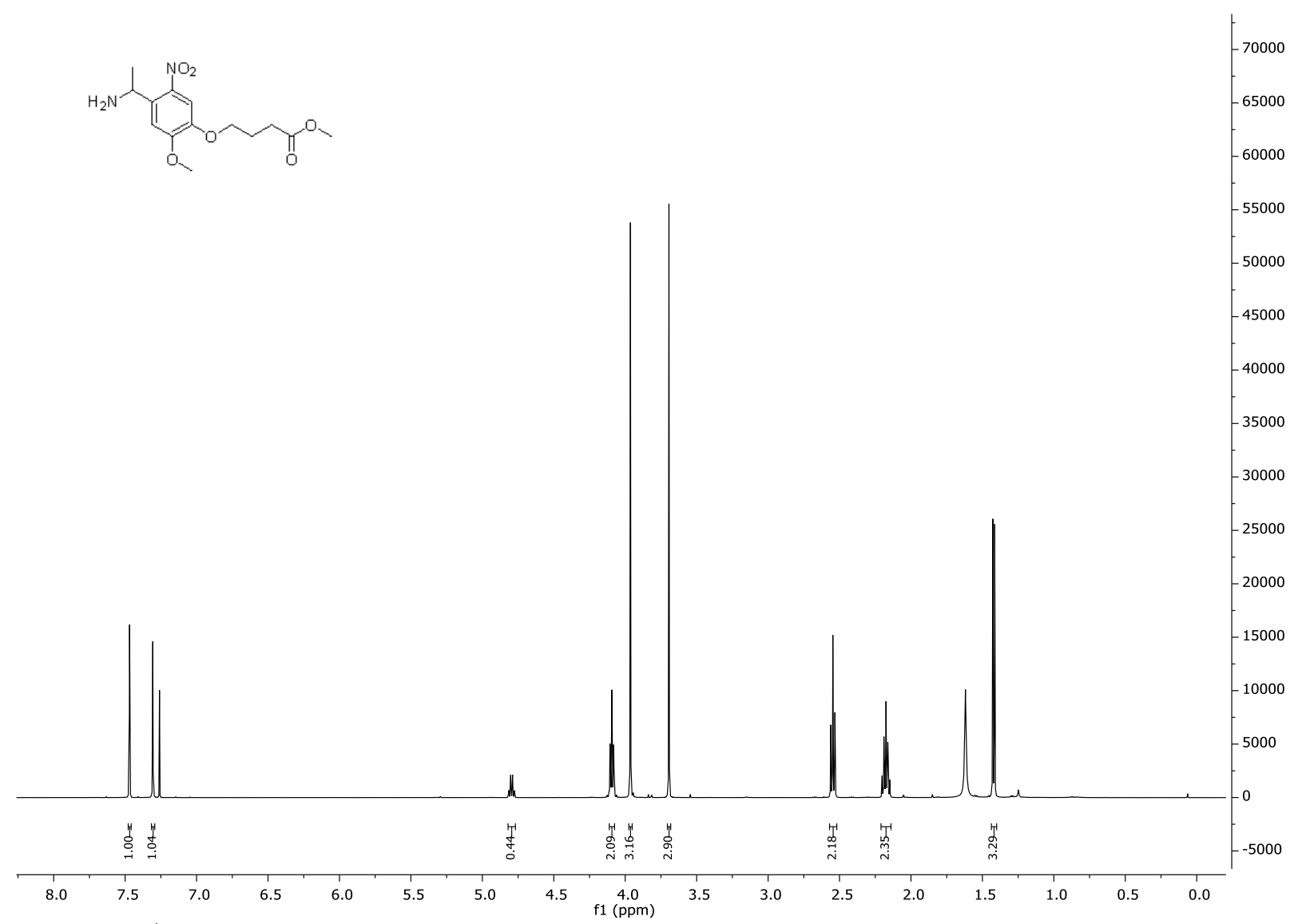

$500 \mathrm{MHz}{ }^{1} \mathrm{H}-\mathrm{NMR}$ in $\mathrm{CDCl}_{3}$ of $\mathbf{9 b}$

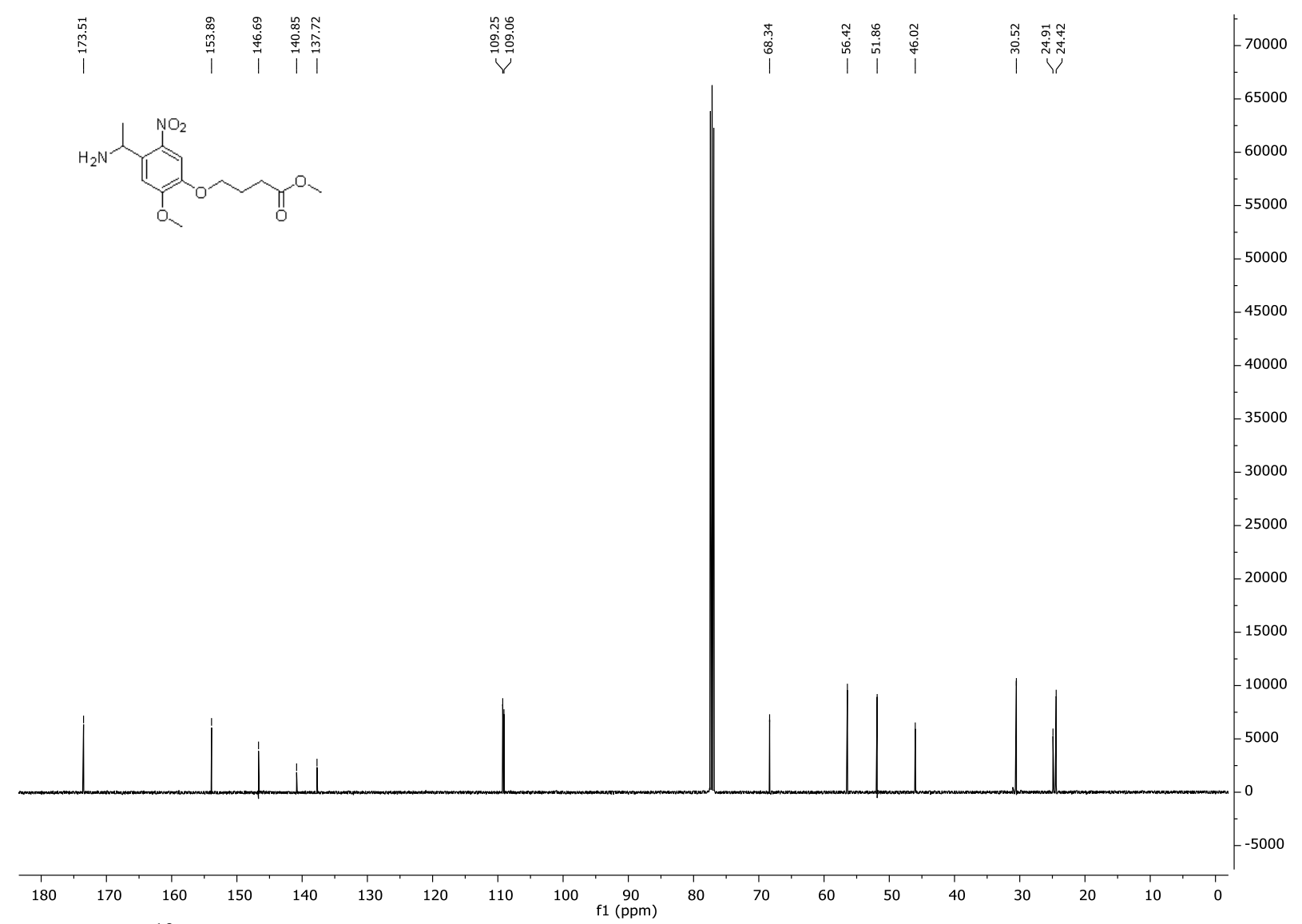

$126 \mathrm{MHz}{ }^{13} \mathrm{C}-\mathrm{NMR}$ in $\mathrm{CDCl}_{3}$ of $\mathbf{9 b}$ 


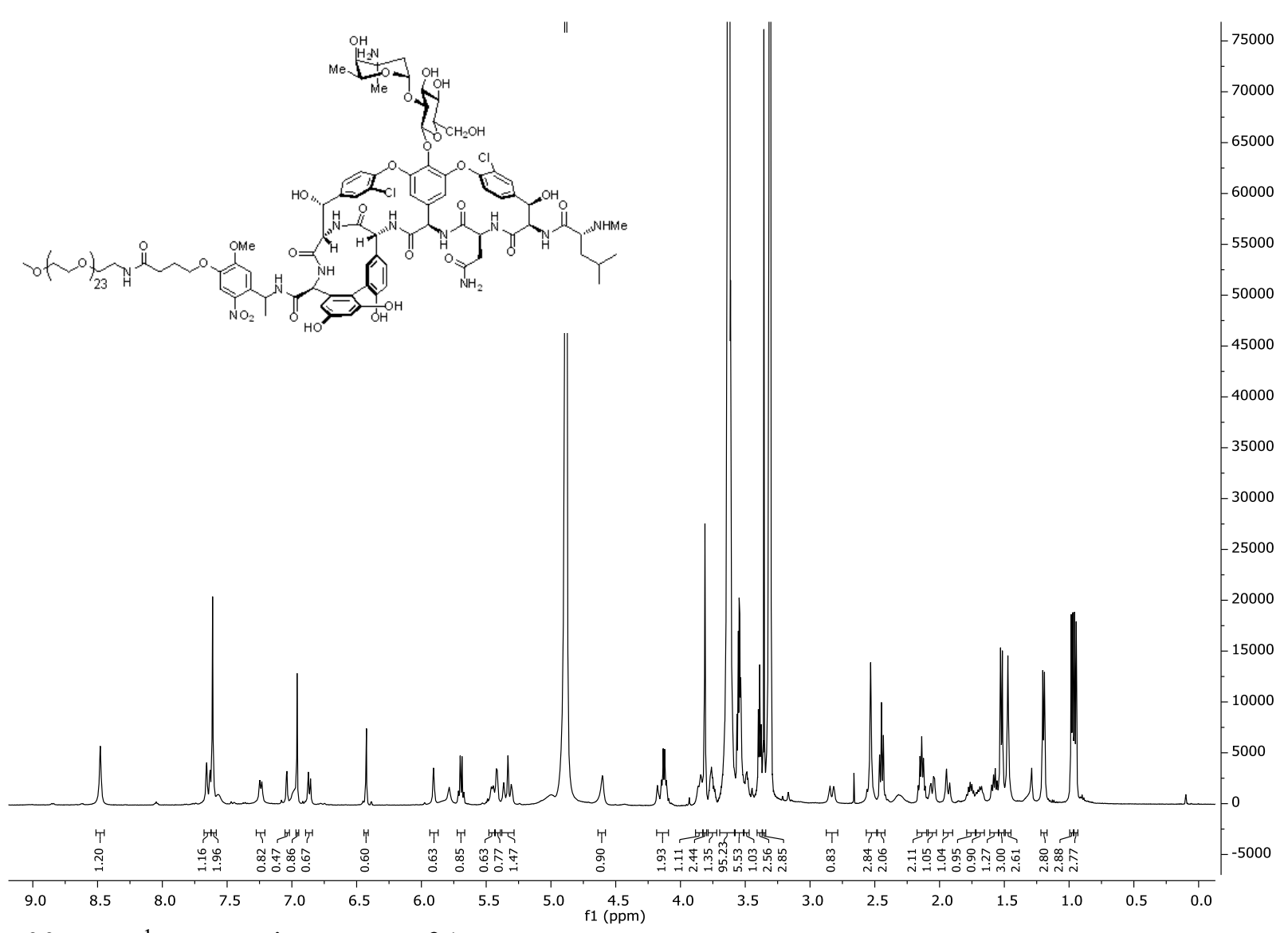

$500 \mathrm{MHz}{ }^{1} \mathrm{H}-\mathrm{NMR}$ in MeOD of $\mathbf{1}$

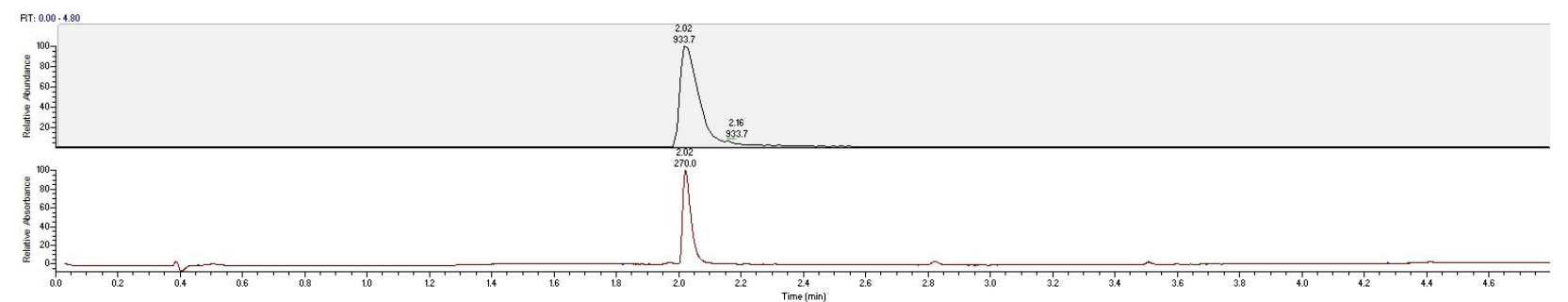

Figure S12. UHPLC trace of compound 1. Top: MS data and retention time of the compound, Bottom: UV-trace of the compound at $270 \mathrm{~nm}$. 


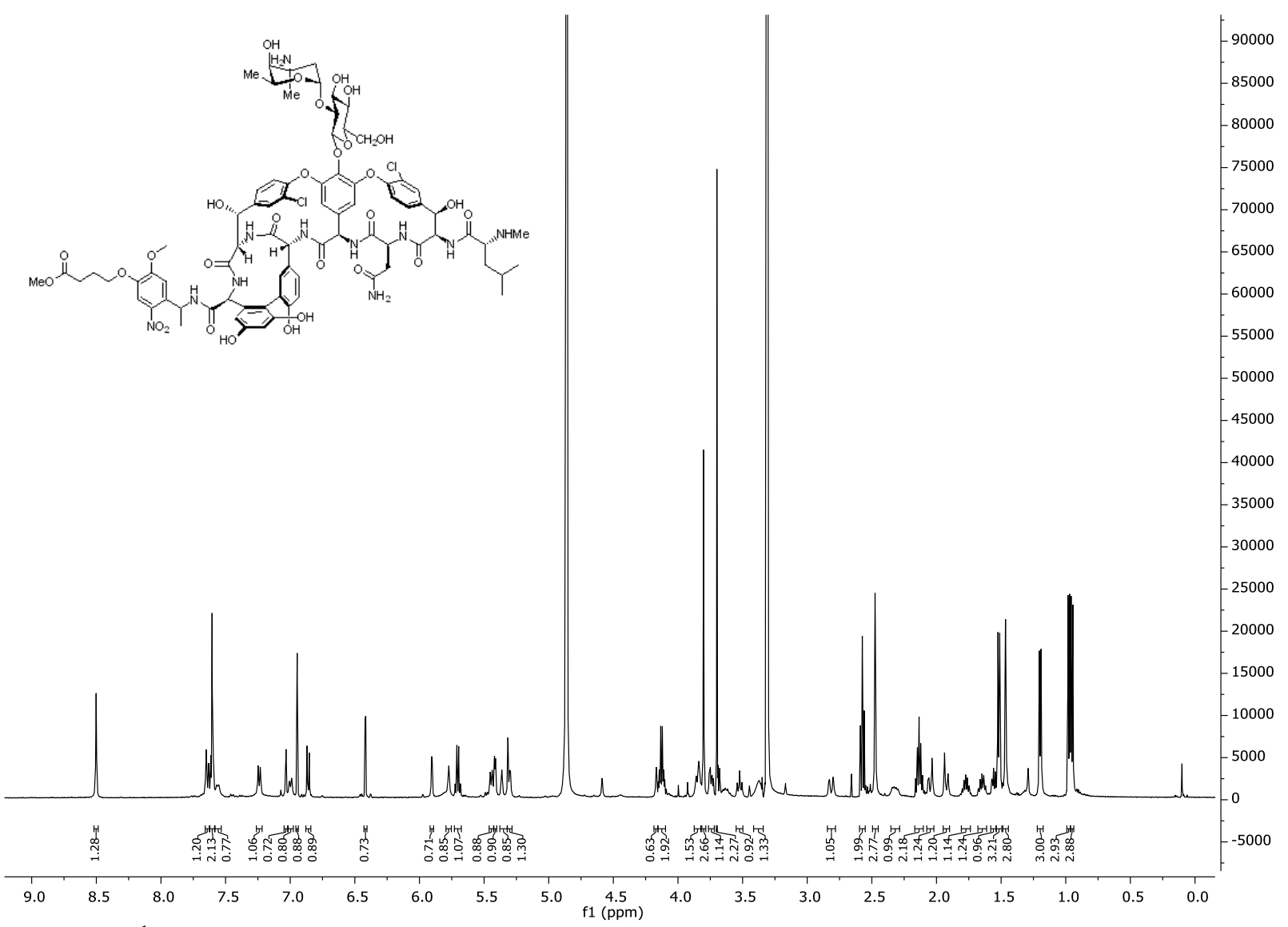

$500 \mathrm{MHz}{ }^{1} \mathrm{H}-\mathrm{NMR}$ in MeOD of 5

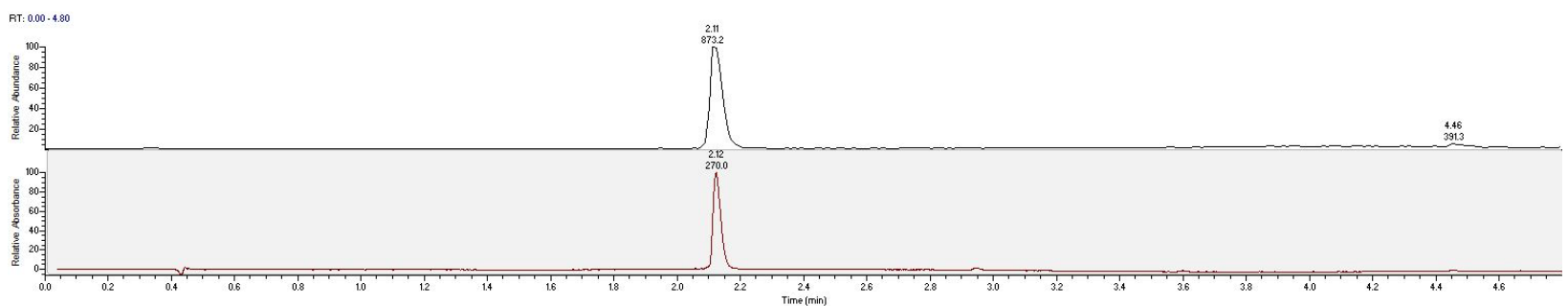

Figure S13. UHPLC trace of compound 5. Top: MS data and retention time of the compound, Bottom: UV-trace of the compound at $270 \mathrm{~nm}$. 


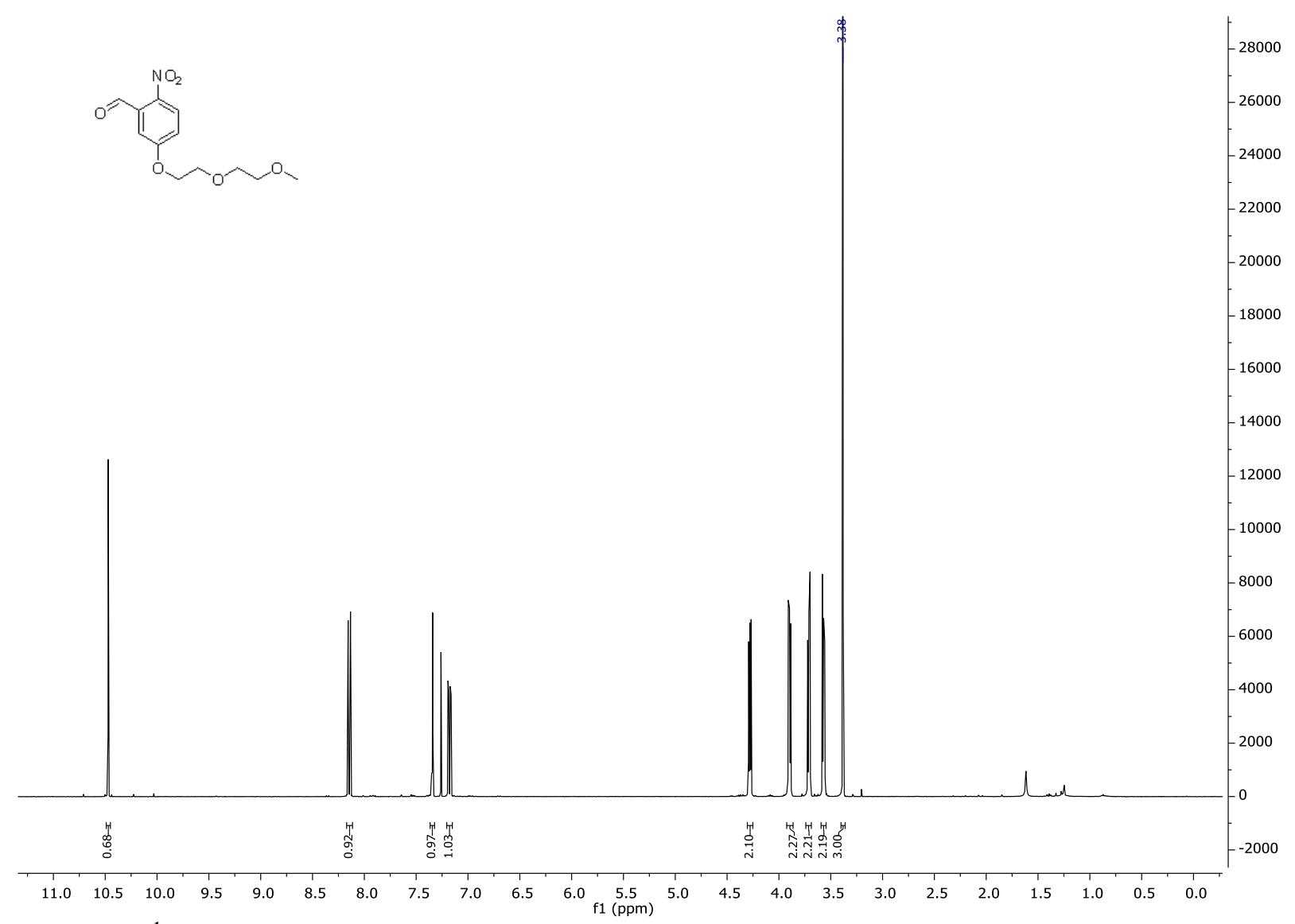

$400 \mathrm{MHz}{ }^{1} \mathrm{H}-\mathrm{NMR}$ in $\mathrm{CDCl}_{3}$ of $\mathbf{1 1 a}$

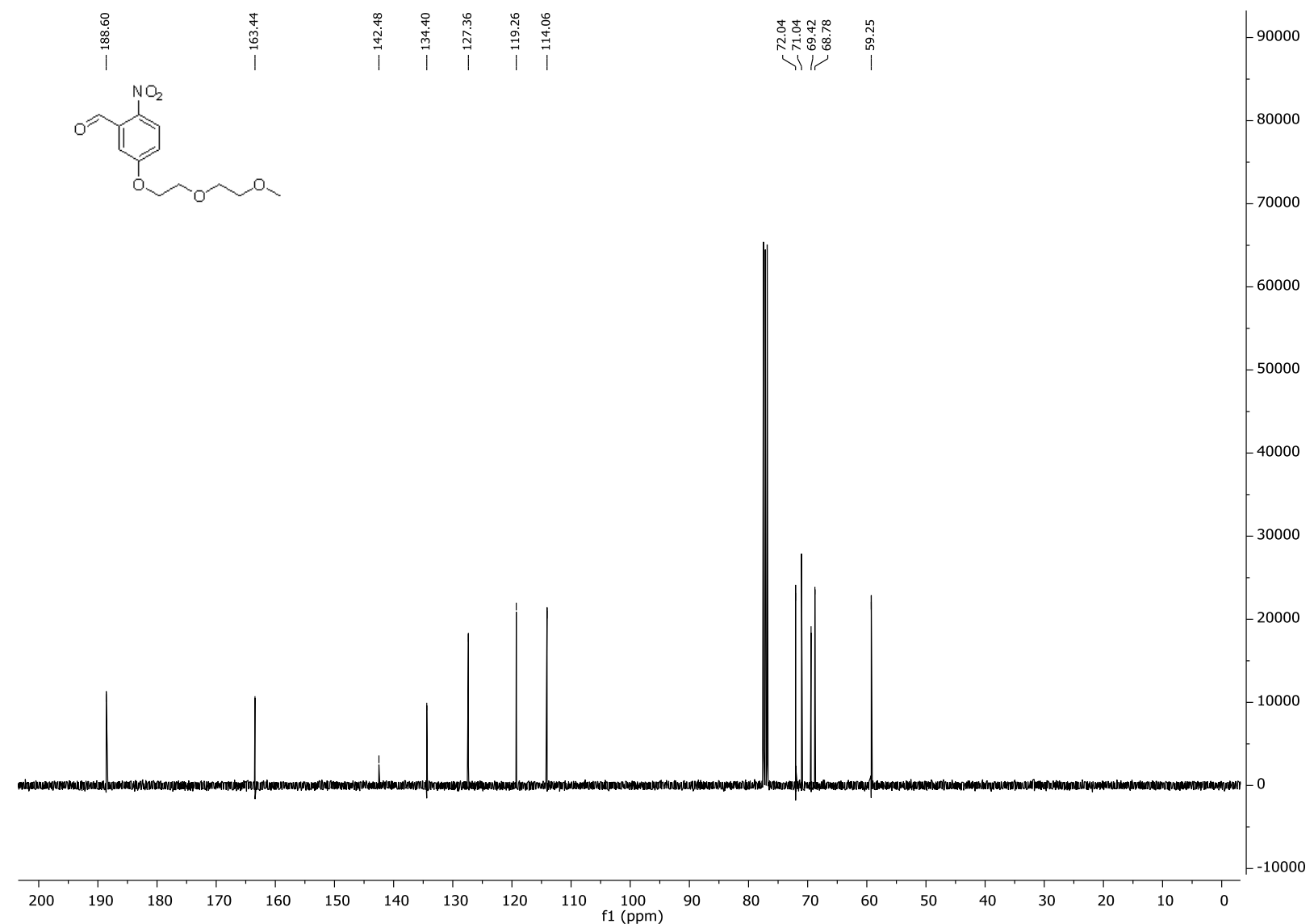

$101 \mathrm{MHz}{ }^{13} \mathrm{C}-\mathrm{NMR}$ in $\mathrm{CDCl}_{3}$ of $\mathbf{1 1 a}$ 


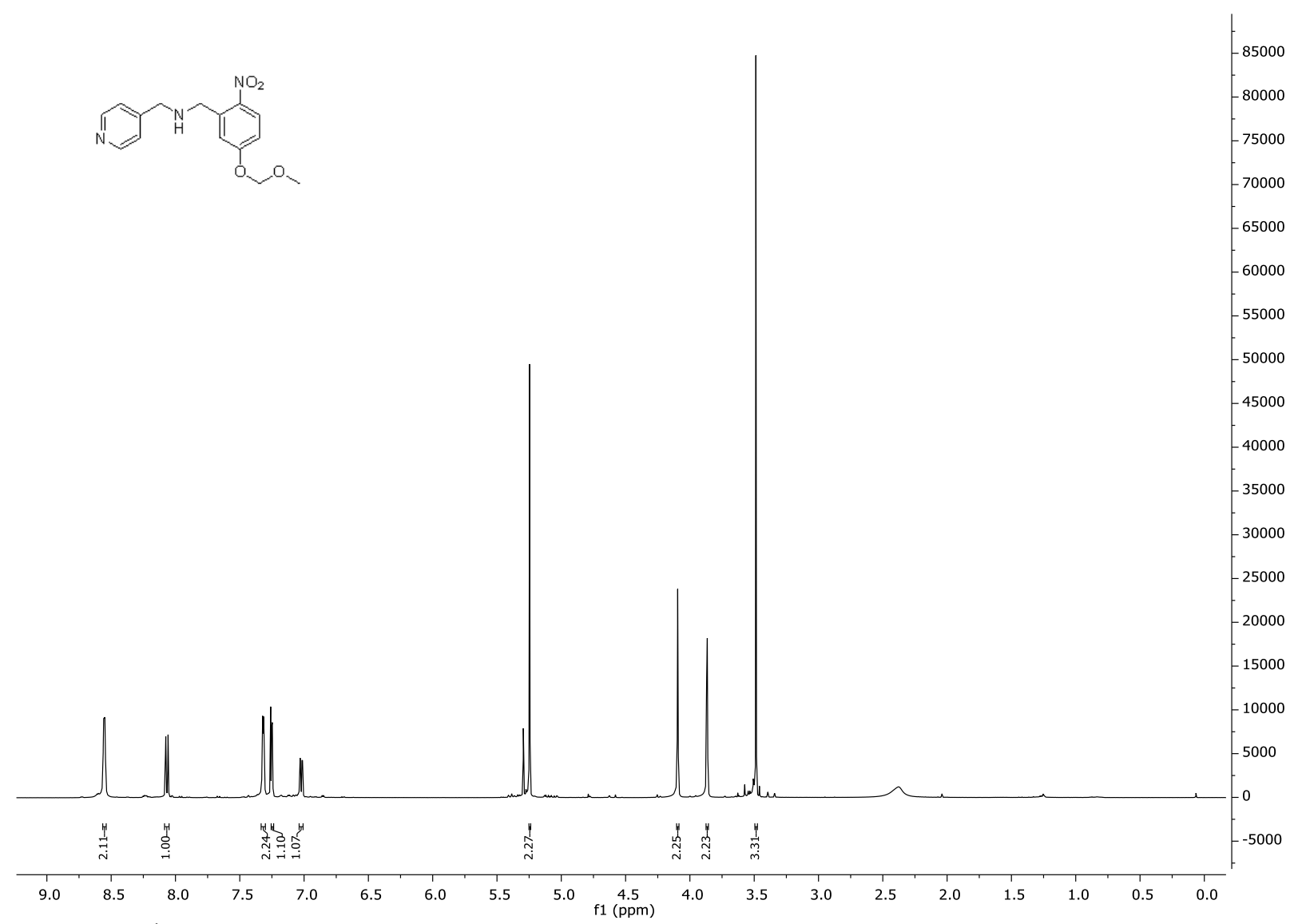

$500 \mathrm{MHz}{ }^{1} \mathrm{H}-\mathrm{NMR}$ in $\mathrm{CDCl}_{3}$ of $\mathbf{1 1 b}$

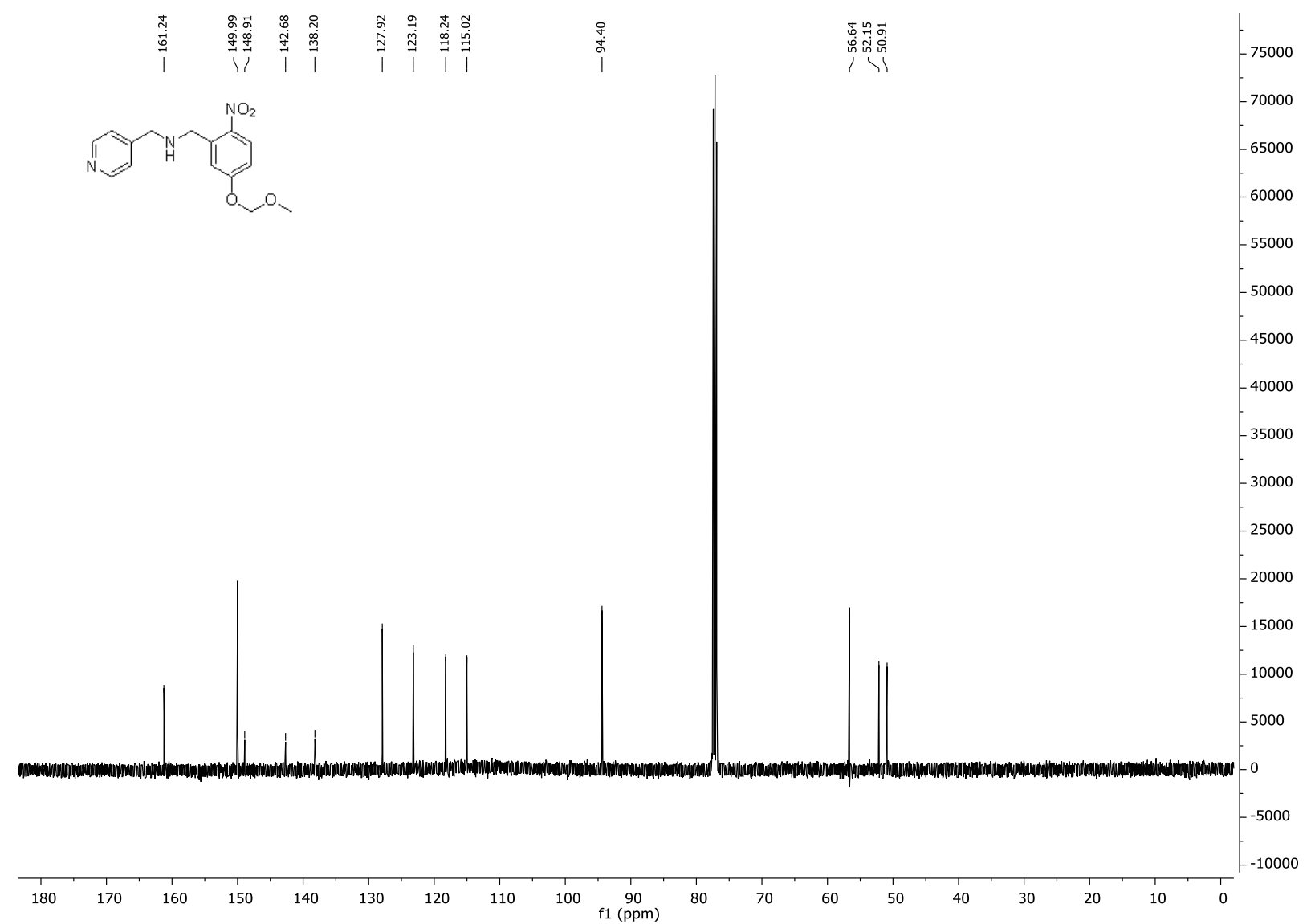

$126 \mathrm{MHz}{ }^{13} \mathrm{C}-\mathrm{NMR}$ in $\mathrm{CDCl}_{3}$ of $\mathbf{1 1 b}$ 


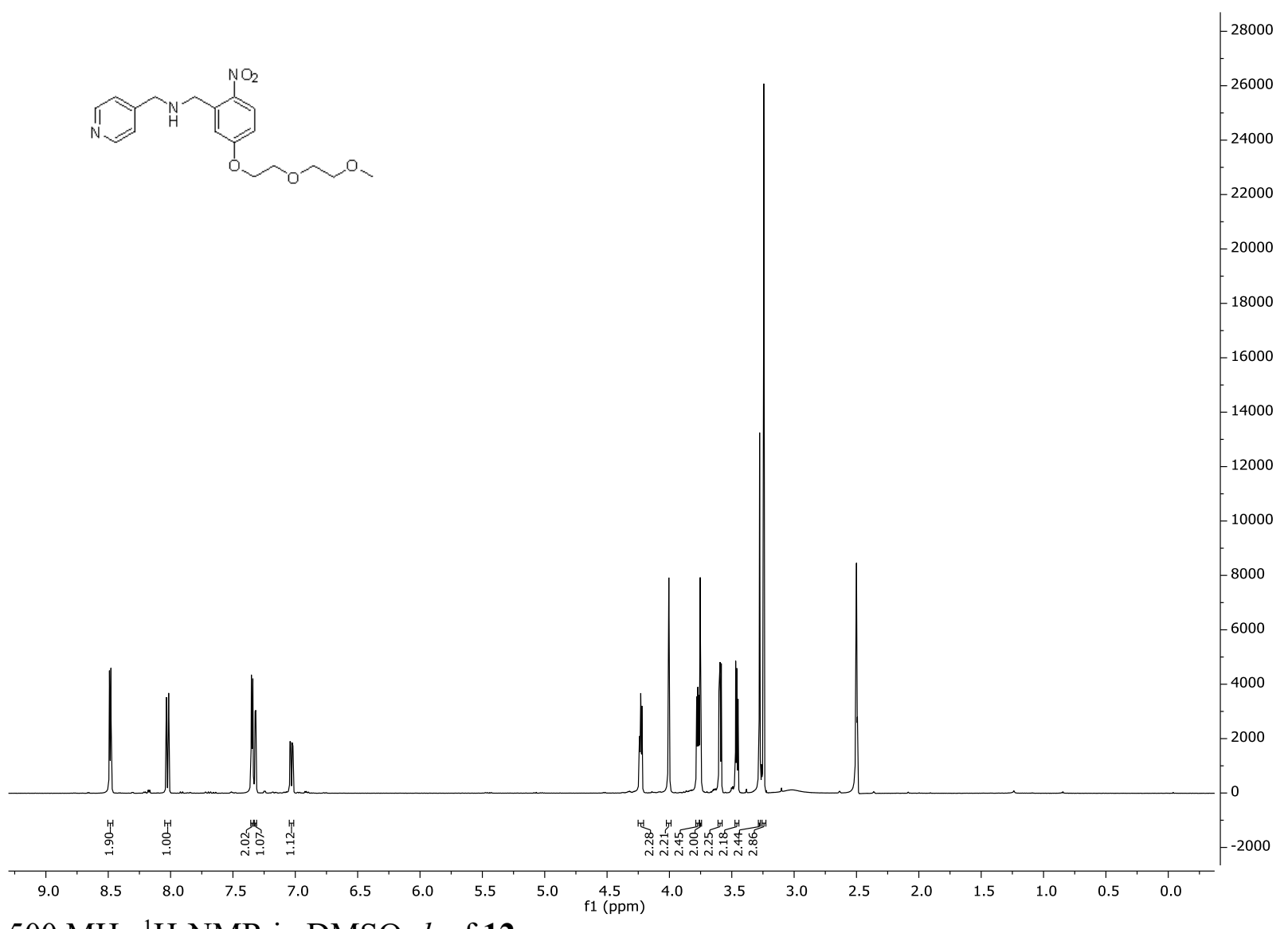

$500 \mathrm{MHz}{ }^{1} \mathrm{H}-\mathrm{NMR}$ in DMSO- $d_{6}$ of 12a
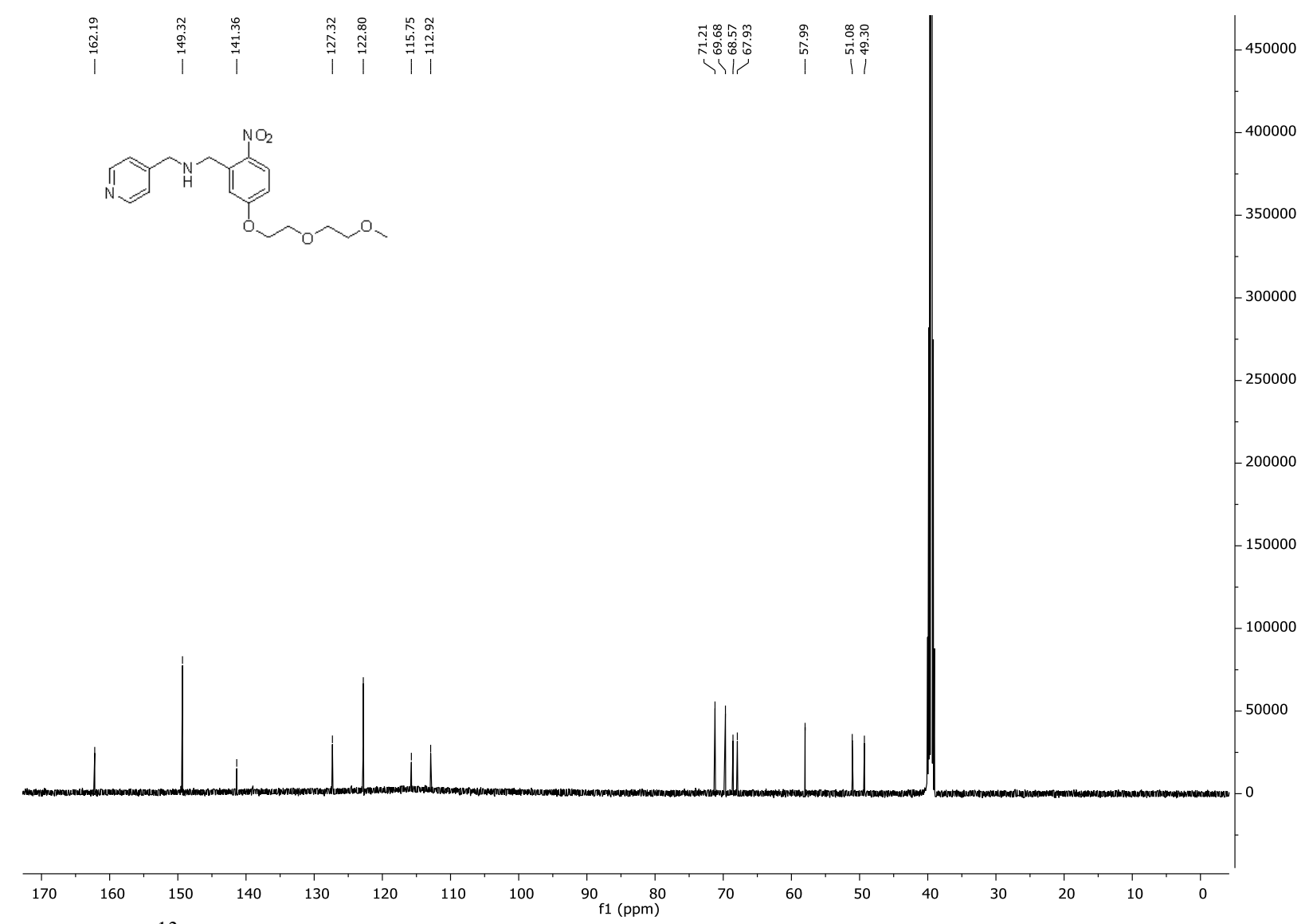

$126 \mathrm{MHz}{ }^{13} \mathrm{C}-\mathrm{NMR}$ in DMSO- $d_{6}$ of $\mathbf{1 2 a}$

S-14 


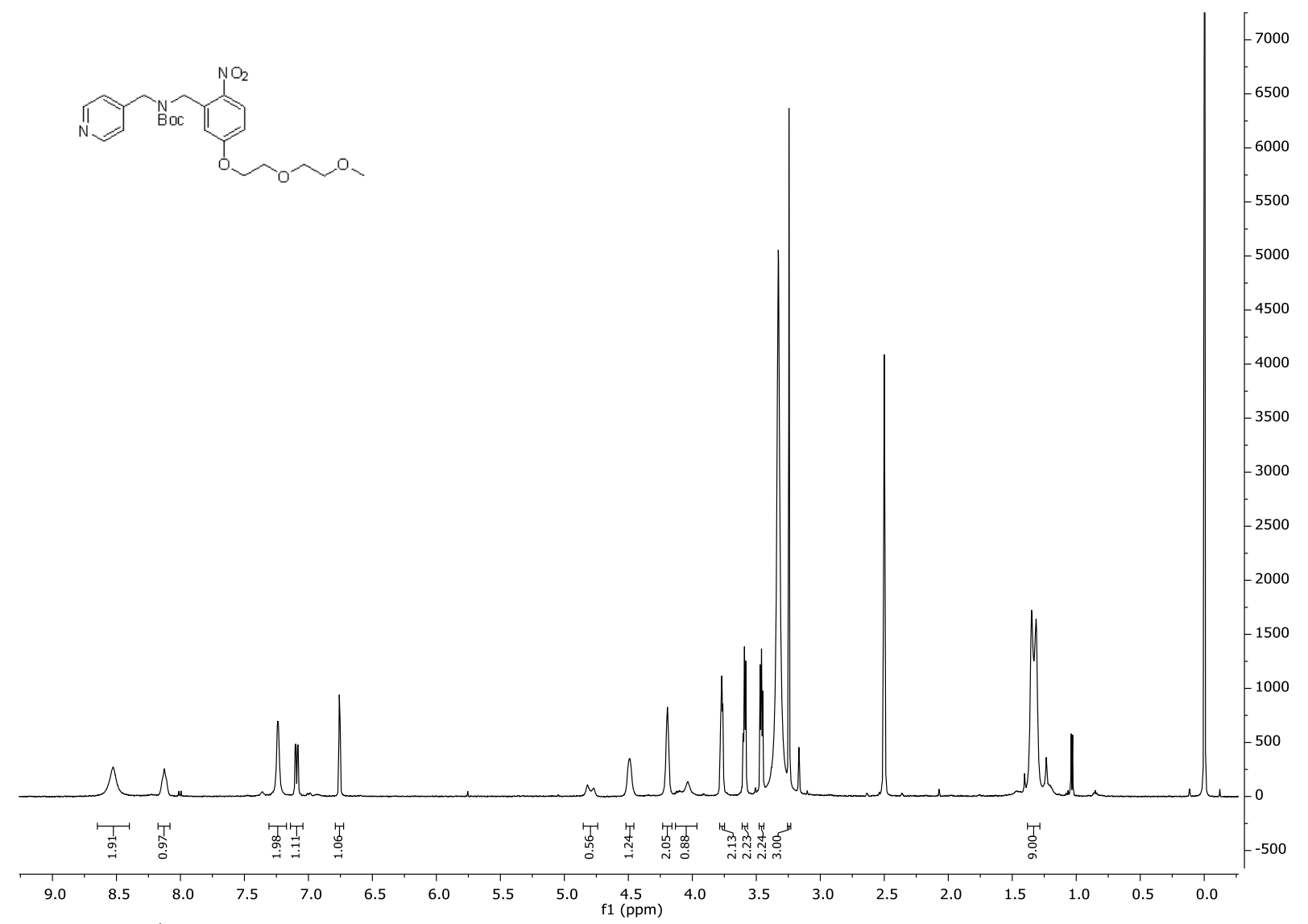

$500 \mathrm{MHz}{ }^{1} \mathrm{H}-\mathrm{NMR}$ in DMSO- $d_{6}+0.1 \% \mathrm{TMS}\left(45^{\circ} \mathrm{C}\right)$ of $\mathbf{1 3 a}$
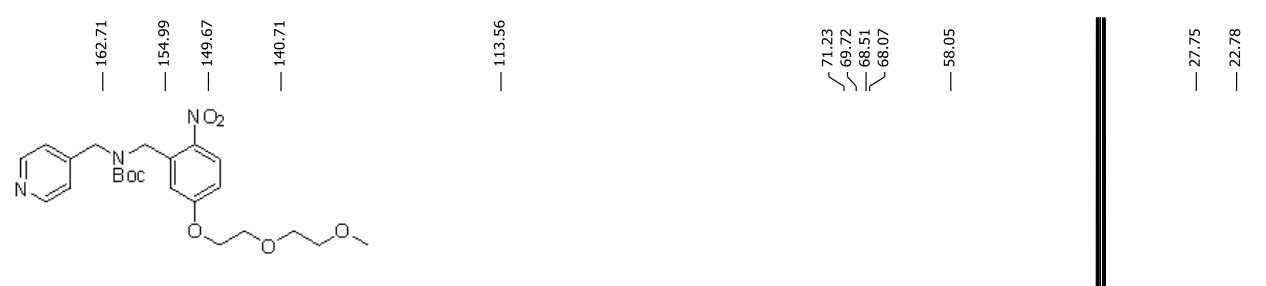

6000

500

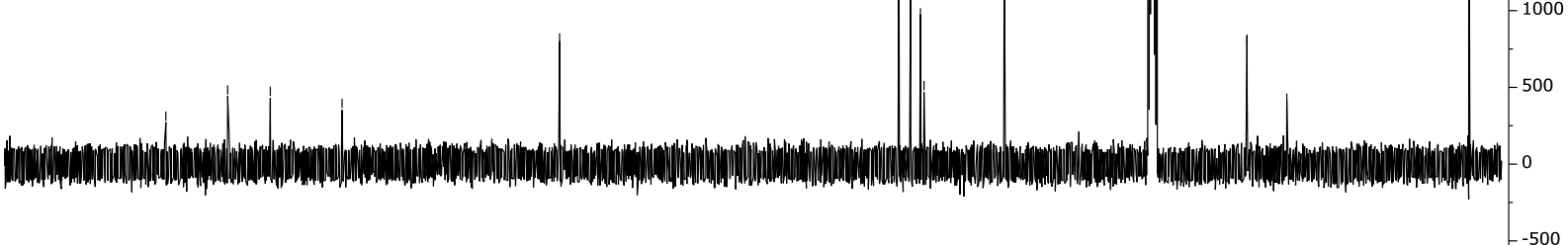
$-500$ $126 \mathrm{MHz}{ }^{13} \mathrm{C}-\mathrm{NMR}$ in DMSO- $d_{6}+0.1 \% \mathrm{TMS}\left(45^{\circ} \mathrm{C}\right)$ of $\mathbf{1 3 a}$ 


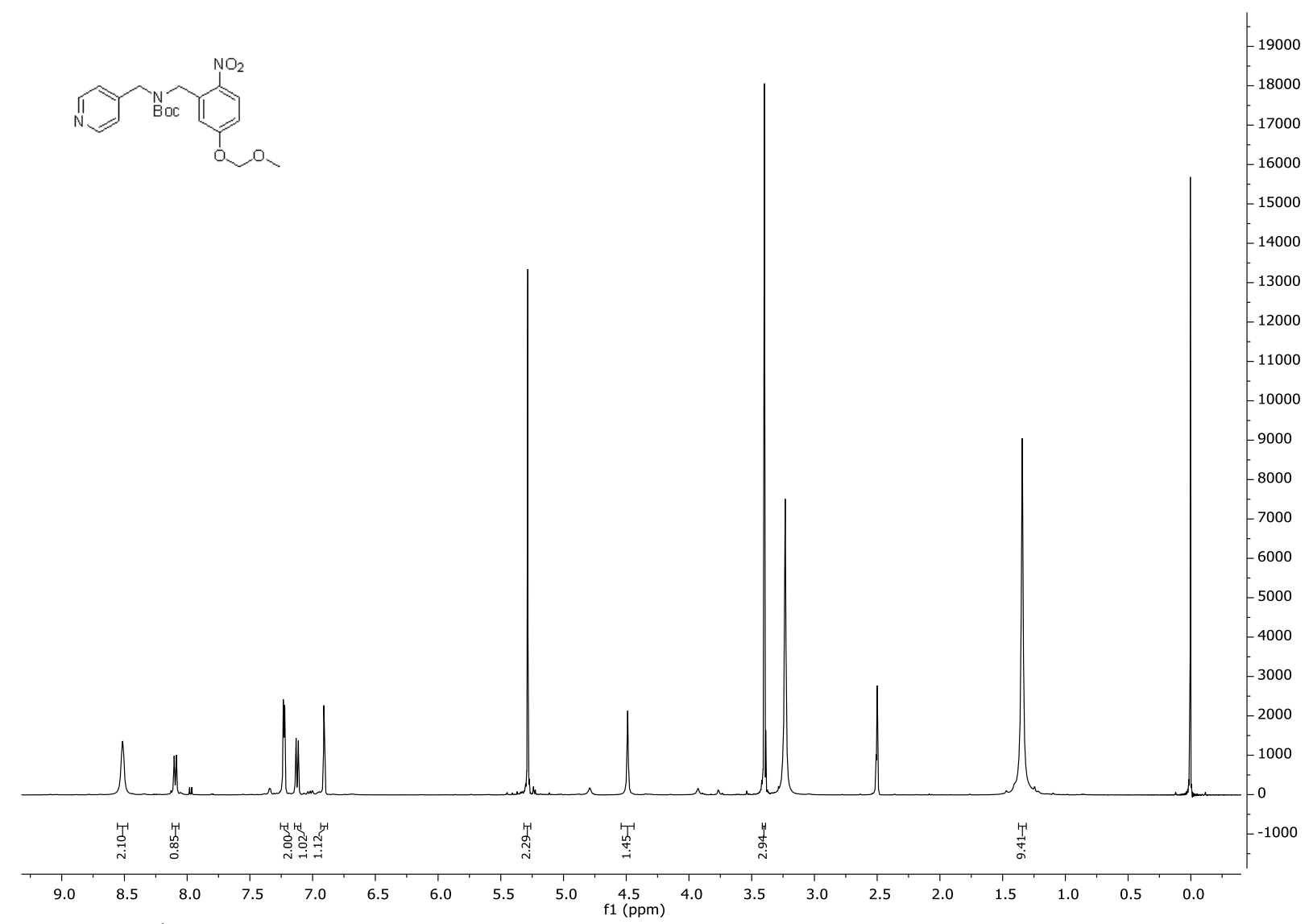

$500 \mathrm{MHz}{ }^{1} \mathrm{H}-\mathrm{NMR}$ in DMSO-d $\mathrm{d}_{6}+0.1 \% \mathrm{TMS}\left(45^{\circ} \mathrm{C}\right)$ of $\mathbf{1 2 b}$

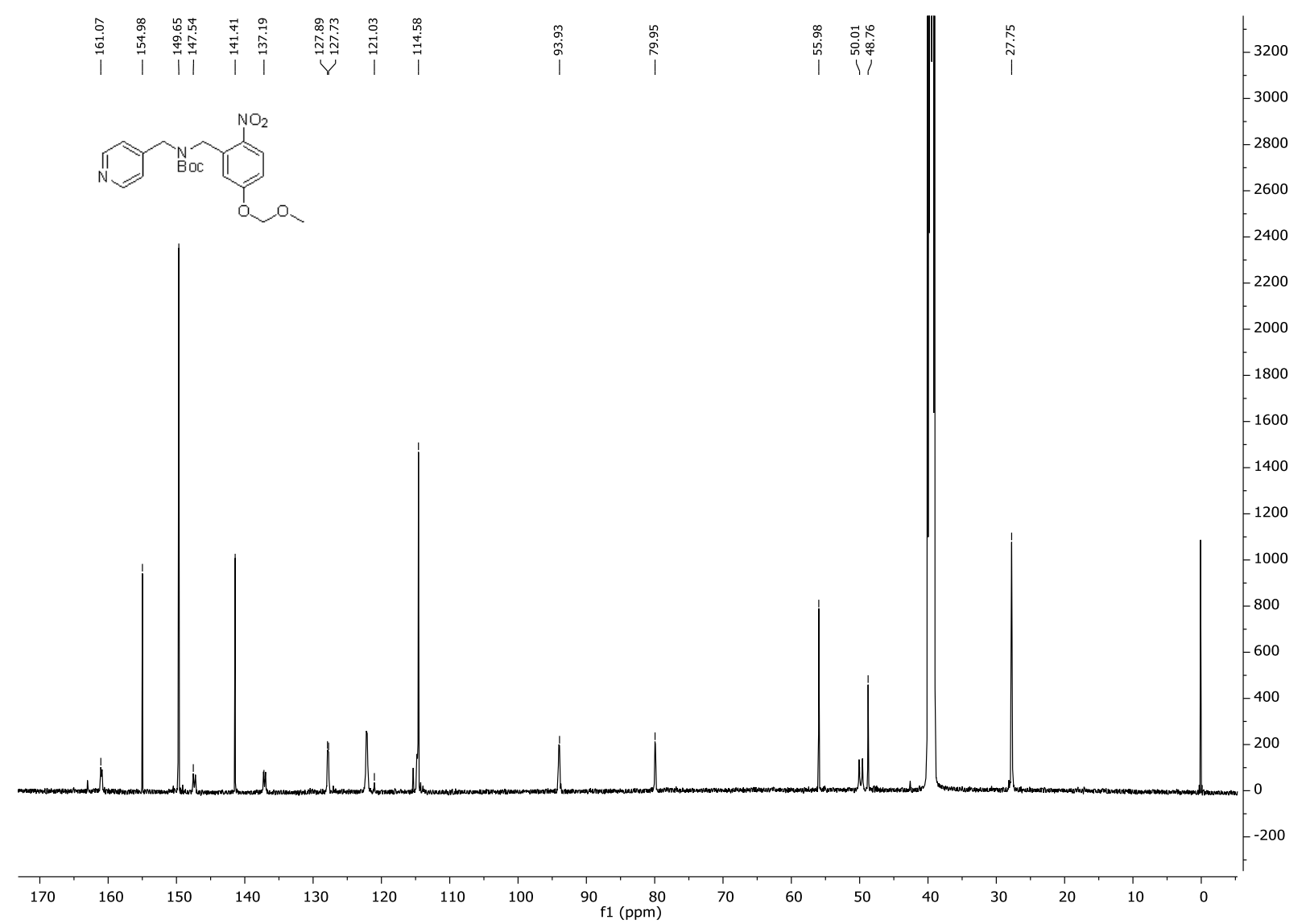

$126 \mathrm{MHz}{ }^{13} \mathrm{C}-\mathrm{NMR}$ in DMSO- $d_{6}+0.1 \% \mathrm{TMS}\left(45^{\circ} \mathrm{C}\right)$ of $\mathbf{1 2 b}$ 


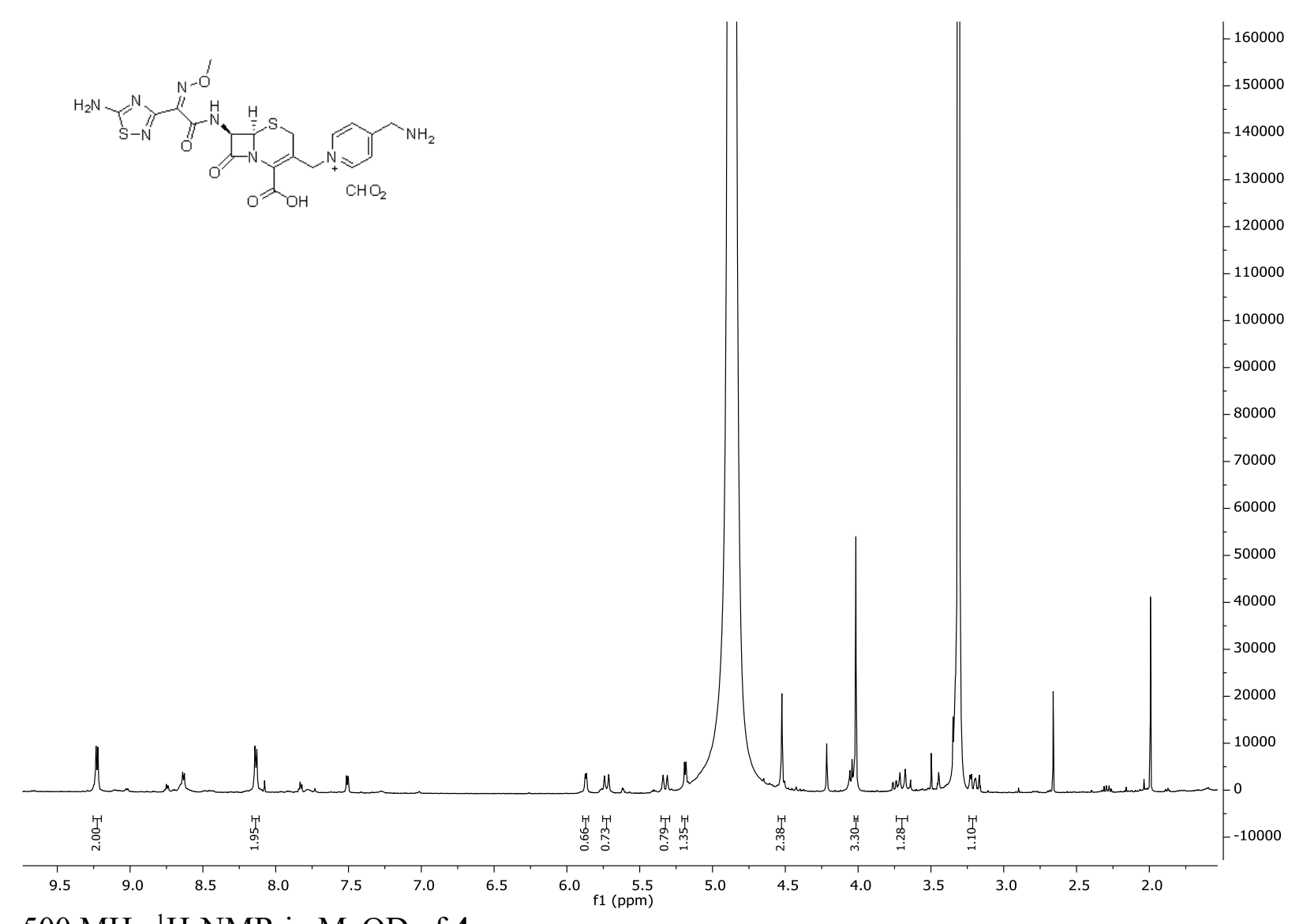

$500 \mathrm{MHz}{ }^{1} \mathrm{H}-\mathrm{NMR}$ in MeOD of 4

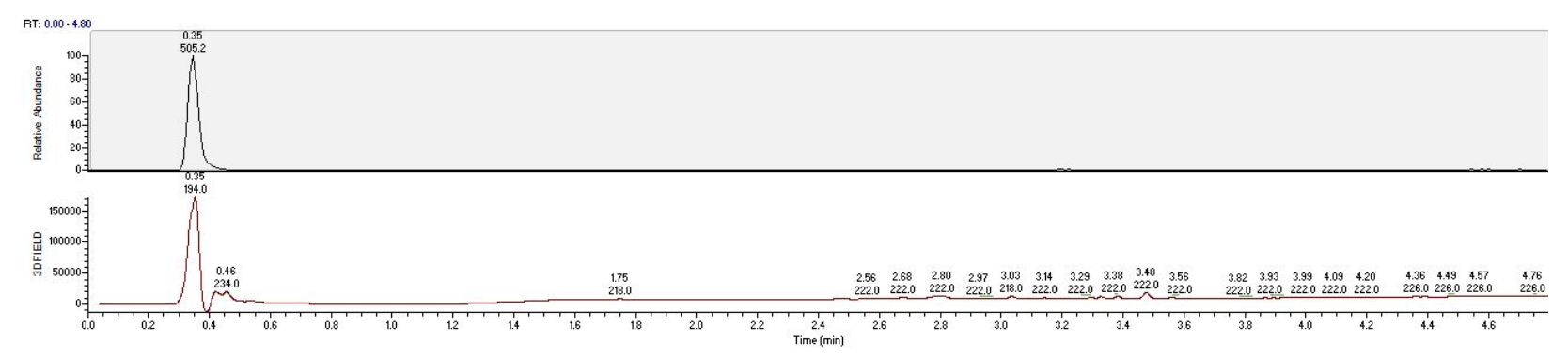

Figure S14. UHPLC trace of compound 4. Top: MS data and retention time of the compound, Bottom: UV-trace of the compound at $270 \mathrm{~nm}$. 


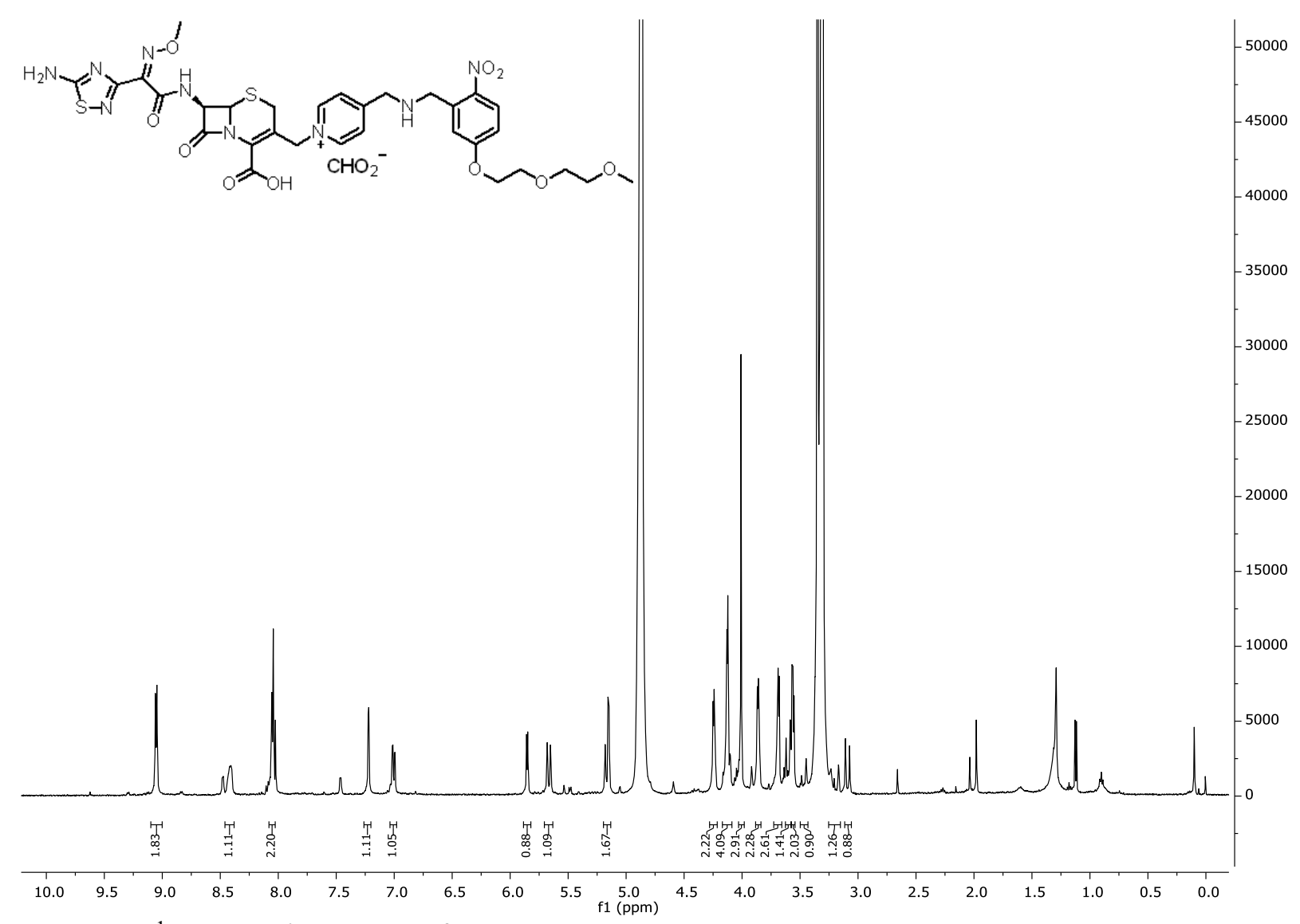

$500 \mathrm{MHz}{ }^{1} \mathrm{H}-\mathrm{NMR}$ in MeOD of 2

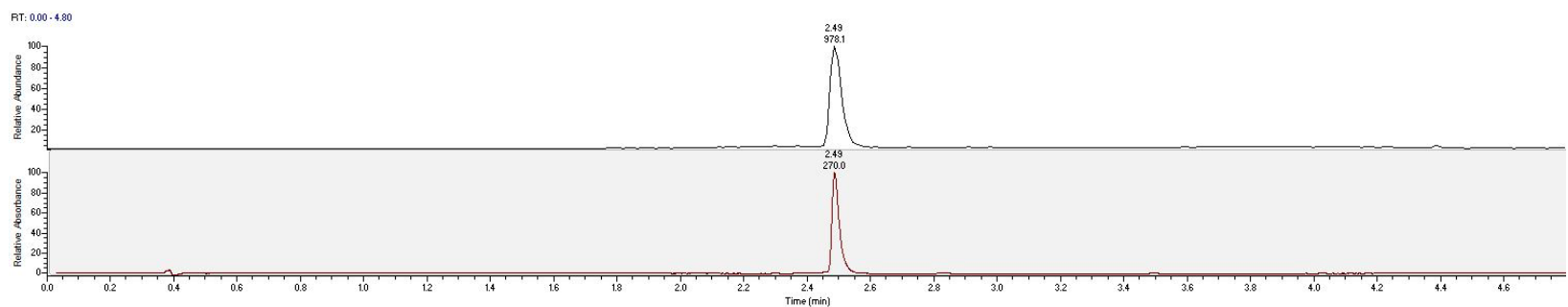

Figure S15. UHPLC trace of compound 2. Top: MS data and retention time of the compound, Bottom: UV-trace of the compound at $270 \mathrm{~nm}$. 


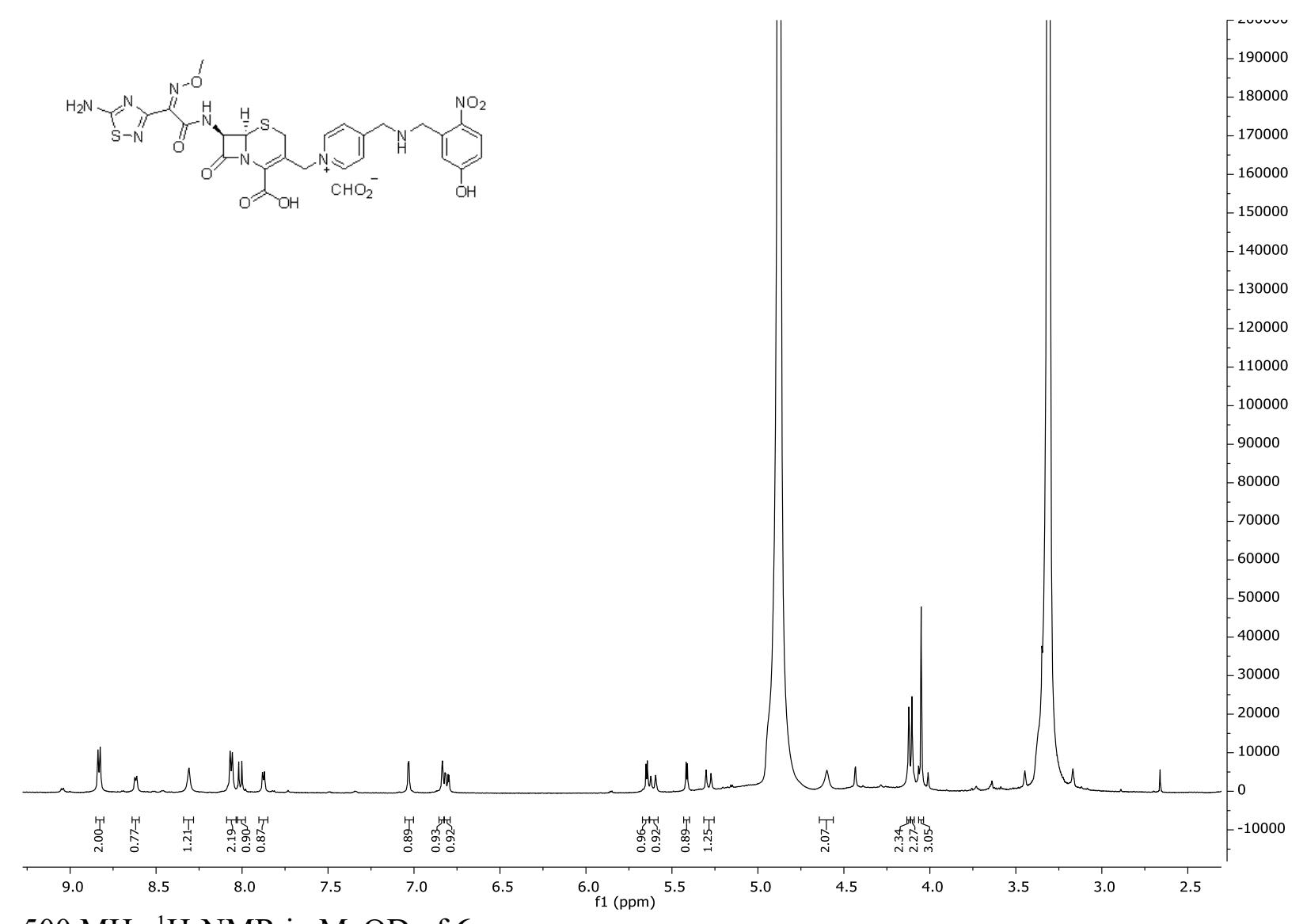

$500 \mathrm{MHz}{ }^{1} \mathrm{H}-\mathrm{NMR}$ in MeOD of 6

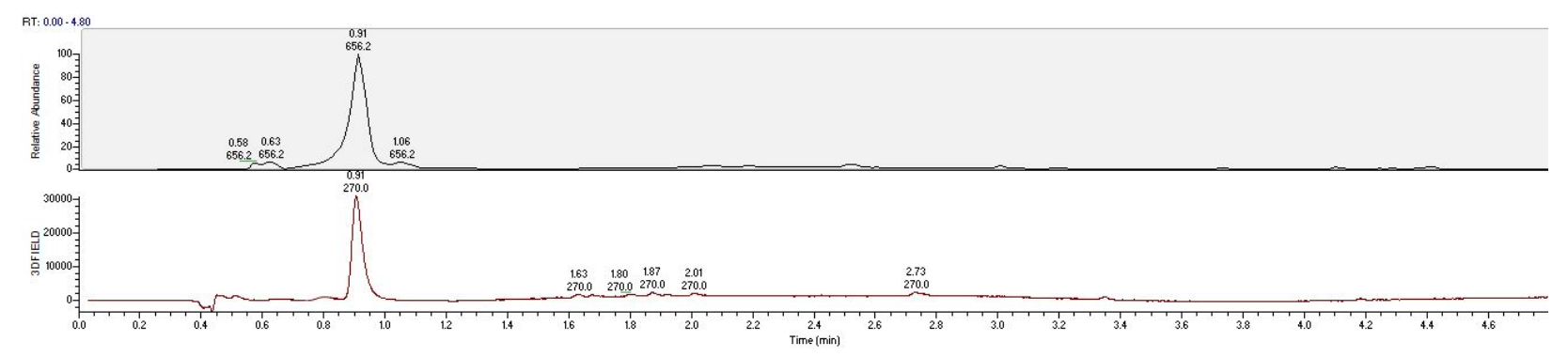

Figure S16. UHPLC trace of compound 6. Top: UHPLC-MS chromatograms of the compound 6 , Bottom: UV-trace of the compound 6 at $270 \mathrm{~nm}$. 